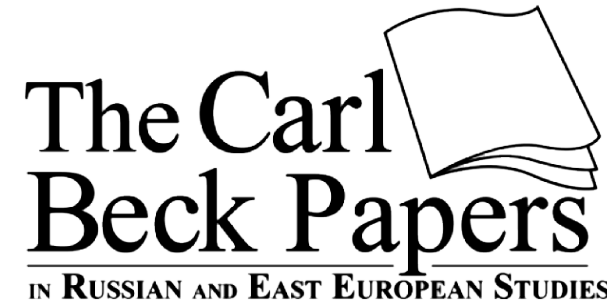

Number 2305
Colin P. Neufeldt

The Public and Private Lives of Mennonite Kolkhoz Chairmen in the Khortytsia and Molochansk German National Raĭony in Ukraine (1928-1934)

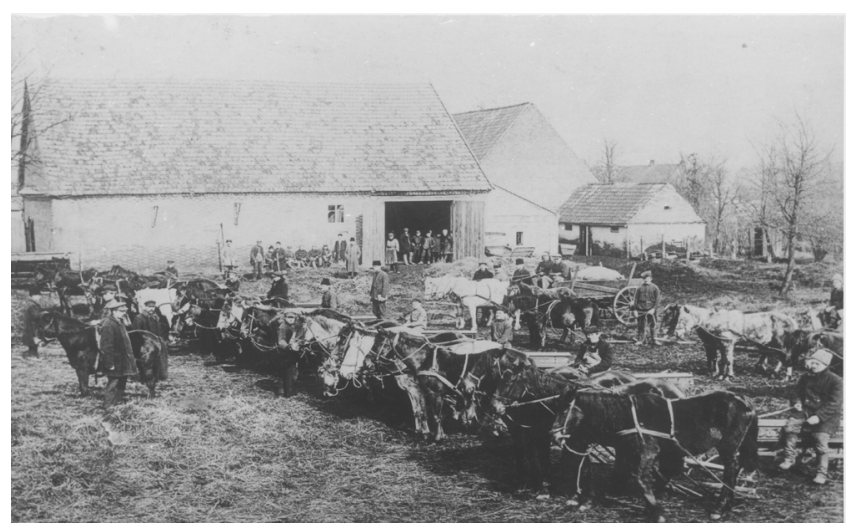




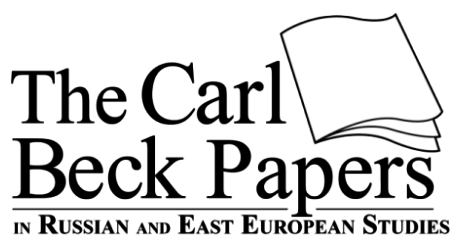

Number 2305

ISSN: 0889-275X (print)

ISSN 2163-839X (online)

Colin P. Neufeldt

\section{The Public and Private Lives of Mennonite Kolkhoz Chairmen in the Khortytsia and Molochansk German National Ră̌ony in Ukraine (1928-1934)}

\section{(CC) $\mathrm{BY}-\mathrm{NC}-\mathrm{ND}$}

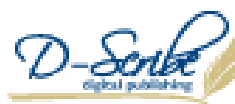

This work is licensed under a Creative Commons Attribution-Noncommercial-No Derivative Works 3.0 United States License.

This site is published by the University Library System of the University of Pittsburgh as part of its D-Scribe Digital Publishing Program, and is cosponsored by the University of Pittsburgh Press. 


\section{Colin P. Neufeldt}

No. 2305, March 2015

2015 by The Center for Russian and East European Studies, a program of the University Center for International Studies, University of Pittsburgh

ISSN 0889-275X (print) ISSN 2163-839X (online)

Image from cover: Mennonite collective farm, 1930. Photo Courtesy of the Mennonite Heritage Centre, Winnipeg, Manitoba.

\section{The Carl Beck Papers}

Publisher: University Library System, University of Pittsburgh

Editors: William Chase, Bob Donnorummo, Andrew Konitzer, Robert Hayden

Managing Editor: Matthew Clews

Editor Emeritus: Ronald H. Linden

Submissions to The Carl Beck Papers are welcome. Manuscripts must be in English, doublespaced throughout, and between 40 and 90 pages in length, including notes. Acceptance is based on anonymous review. Manuscripts can be submitted on The Carl Beck Papers website, http://carlbeckpapers.pitt.edu. Please direct all inquiries to Matthew Clews, Managing Editor, at carlbeckpapers@mail.pitt.edu. 
This article examines the role that Mennonites played in the establishment and management of kolkhozy in the two largest Mennonite settlements (Khortytsia and Molochansk) in Soviet Ukraine during dekulakization and collectivization (1928-1934). More specifically, it investigates the social and ethnic criteria used in selecting Mennonites to be kolkhoz chairmen; the duties and daily routines of chairmen; the conflicted relationships that chairmen had with local authorities and kolkhoz members; the numerous challenges that chairmen encountered during the 1932-33 famines; and the mechanisms that local authorities and kolkhoz members used to control, embarrass, and discipline chairmen. It also discusses the negative repercussions that the rise of Nazi Germany had for Mennonite chairmen, and how political, economic, agricultural, social, and ethnic policies and conditions made it very difficult for Mennonite chairmen to succeed. 
The author thanks Lynette Toews-Neufeldt, Wesley Berg, Johann Esau, William J. Chase, Matthew Clews, the editorial staff at the Carl Beck Papers, and the anonymous reviewers for their comments and suggestions in preparing this article. 


\section{"The Public and Private Lives of Mennonite Kolkhoz Chairmen in the Khortytsia and Molochansk German National Raĭony in Ukraine (1928-1934)"}

\section{Introduction}

In July 1934, an embarrassing article appeared in Stürmer, a newspaper published by the Khataevich Machine Tractor Station, which circulated among Mennonite and Ukrainian villages in the former Mennonite colonies of Khortytsia (Chortitsa) and Yazykovo near Zaporizhia, Ukraine. The article alleged that comrade Ens, the Mennonite chairman of the Torgler collective farm (kolkhoz in Russian; kolhosp in Ukrainian) near the town of Khortytsia, was playing favorites with Sarah Koop, a single mother who worked in the pig barns at Torgler. ${ }^{1}$ According to the article, Koop had become a "radiant beam on the face of Chairman Ens," who was doing everything that he could to keep her happy. He rigged a kolkhoz lottery to ensure that Koop won a prize calf; he provided extra benefits to her at the expense of more deserving kolkhoz members; and he ensured that she and her daughter lived rent-free in three rooms of a kolkhoz house, while members of the kolkhoz administration had to pay rent for overcrowded quarters. Why did Ens, a married man, perform special favors for Koop? According to the Stürmer article, it was because Chairman Ens had become a regular guest at the drinking parties that Koop hosted for Ens and other men at her residence. ${ }^{2}$ Scandalous accounts of the alleged vices of Mennonite kolkhoz chairmen were not uncommon in Stürmer in the early 1930s. Almost every issue contained letters and articles detailing the corrupt practices and un-Soviet acts of Mennonite and non-Mennonite kolkhoz officials in the Khortytsia and Yazykovo area. These articles were sometimes based on anonymous poisonpen letters that lacked corroborating evidence, but journalistic integrity and factual reporting were not the primary concerns of the editors of Stürmer. The newspaper also served as a forum for kolkhoz members to vent their frustrations with kolkhoz chairmen, bring to light alleged abuses and corruption of chairmen, and parrot government expectations of chairmen in the administration of their kolkhozy.

Newspapers such as Stürmer provide a fascinating perspective on the public attacks that many kolkhoz chairmen had to endure, but unfortunately they do not 
provide a complete or entirely accurate picture of what life was really like for kolkhoz chairmen in the early years of collectivization. In fact, virtually nothing has been written about the experiences of Mennonite kolkhoz chairmen, the role they performed in collectivizing the Soviet countryside, the challenges they encountered in organizing and managing kolkhozy during the early days of Soviet collectivization, or the expectations placed upon them. There are historical accounts that examine the role of Soviet kolkhoz chairmen in the late 1920s and early 1930s, but they present the experiences of kolkhoz chairmen as a singular history and do not delineate the unique challenges and issues that chairmen of different ethnic and religious backgrounds endured during Soviet collectivization. ${ }^{3}$ Questions arise as to whether any of the challenges and experiences of Mennonite kolkhoz chairmen were significantly different from those of non-Mennonite kolkhoz chairmen. This article will endeavor to address some of these lacunae by focusing on the public and private lives of Mennonite kolkhoz chairmen who served in the two regions in Ukraine with the largest number of Mennonite communities: the German national răony (districts) of Khortytsia, located on the western bank of the Dnieper River, and Molochansk, situated along the Molochna River northeast of Melitopol. These two raĭony were the location of the oldest and most influential Mennonite settlements in Ukraine.

\section{Kolkhozy in the Mennonite Countryside}

That Mennonites served as Soviet kolkhoz chairmen is in some respects astonishing, given the conflicted and distrustful relationship that existed between Soviet authorities and Mennonite communities in Ukraine. ${ }^{4}$ The Bolshevik seizure of power in 1917 ushered in a new socialist regime that was unfamiliar to the Mennonites and unsympathetic to their interests. In the eyes of many Mennonites, the Bolshevik regime was responsible for the destruction of their communities and represented the personification of evil. As descendants of sixteenth-century Dutch, German and Swiss Anabaptists, the Mennonites' interpretation of Christianity rejected the use of violence, and instead espoused peaceful non-resistance, the separation of church and state, and voluntary membership in the church symbolized by adult baptism. They also considered themselves as brothers and sisters in the Lord, and therefore equal in status, with no one, not even a pastor, superior in religious faith or ability. Their emphasis on purity of life meant nonconformity to the spirit, 
ideals, and culture of the non-Christian world, avoiding support for and participation in government institutions whenever possible, and if necessary exercising discipline on those members who deviated from the Mennonite standard. Whenever possible, they lived in separate communities in order to provide mutual support and prevent the infiltration of secular ideologies and practices into their homes and congregations. ${ }^{5}$

When Mennonite colonists first settled in Russia in the late eighteenth and early nineteenth centuries, the soslovie system of social classification that existed in tsarist Russia suited them very well. For more than a century, the tsars organized Russian society according to soslovie groups (such as the nobility, state officials, clergy, townspeople, and peasants), each owing special service obligations to the tsar and the Russian state. In this system, no two soslovie groups were equal, and the government treated each group differently according to their own privileges, service obligations, and status. The Mennonites had negotiated special privileges with Catherine the Great, and later with her son Paul, which allowed them to easily fit into the soslovie system and included service obligations that were different from the obligations owed by their non-Mennonite neighbors. In this system, the Mennonites viewed themselves as a unique group with a special relationship to the tsar. ${ }^{6}$

The Bolsheviks, however, swept the old soslovie system aside and replaced it with their own neo-soslovie system; it reclassified Russian society along Marxist socio-economic lines and made class divisions of utmost importance. The Bolsheviks considered the "socially-friendly" classes-bedniaki (poor peasants), batraki (landless agricultural workers) and urban industrial workers- to be their allies in their revolutionary struggle. "Socially-neutral" groups, such as seredniaki (middle peasants), posed no particular threat to the Bolsheviks. However, they considered the "socially-alien" classes to be enemies of the state; these included kulaks (prosperous peasants who exploited hired labor and were often referred to as ekspertniki [experts] in Ukraine), and byvshie (former people such as nobles, estate owners, tsarist officials, factory owners, industrialists, clergymen, and White Army participants). ${ }^{7}$ In the opinion of the Bolsheviks, the Mennonite community was a German-speaking, ethno-religious sect that did not fit easily into their class ideology. Furthermore, the pre-revolutionary wealth of the Mennonites, their enthusiastic support for the German Army during the First World War and the White Army during the Russian Civil War, and their organization of Selbstschutz (self-defense corps) units to defend their communities against anarchists and the Red Army during the civil war, convinced many Soviet authorities that a large segment of the Mennonite population was either kulak or byvshie, and therefore counter-revolutionary. ${ }^{8}$ 
In Bolshevik class ideology, however, there was no such thing as a kulak community per se, and so it was impossible to categorize all Mennonites as counterrevolutionaries. At the same time, there were some bedniak and batrak Mennonites who supported the Bolshevik cause during the revolution and civil war, even though they were still part of the Mennonite community and participated in its religious and cultural life to varying degrees. The Bolsheviks wanted to incorporate these Mennonite bedniaki and batraki into their new Soviet state, but this was not easy since the new regime did not recognize ethno-religious groups, such as Mennonites, as separate national groups. The Bolshevik leadership also had difficulty fitting the Mennonites into one of its national categories; it initially categorized the Mennonites as Dutch, but eventually treated them as Germans and accorded them the benefits of having a German national identity. As such, the Mennonites had the right to use and teach the German language in their settlements. But as Germans, the Mennonites were also the targets of anti-German hostility that had existed in pre-revolutionary Russia and continued to thrive in the new Soviet state. At the village level, for example, Soviet authorities routinely exhibited their anti-German antipathy by implementing discriminatory measures - such as higher tax-in-kind assessments and labor-service requirements - and inciting physical attacks against some Mennonite communities. ${ }^{9}$

Anti-German sentiment was not the only type of hostility that Mennonites had to endure at this time. Increasing anti-religious sentiment, much of it incited by the Bolshevik leadership, also created difficulties for Mennonite settlements. Within months of the revolution, for instance, the new Soviet government implemented the Decree of 23 January 1918 - a law that separated church and state, but which also legalized Bolshevik antipathy toward religious organizations. ${ }^{10}$ The decree allowed the government to confiscate church property and denied religious organizations legal status as persons at law. This meant that churches had no juridical status in the courts nor did they have the right to own property; congregations could only use seized church buildings if they first obtained the permission of local authorities. The decree also prohibited all religious instruction in schools on the pretext that it would create a universal and secular education system. By 1921 Bolshevik authorities were investigating Mennonite teachers concerning their religious views and dismissing those who had served as church ministers or refused to implement a secular curriculum in the classroom. ${ }^{11}$

While the Bolsheviks' anti-religious laws applied to all religious organizations, the Bolsheviks did not treat every religious group the same way. In fact, the Bolsheviks initially targeted most of their anti-religious attacks against the Russian Orthodox Church, while simultaneously implementing polices that benefited sectarian 
groups, including the Mennonites, Baptists, Seventh-Day Adventists, and Tolstoyans. The Bolshevik leadership hoped to win the support of these groups and believed that offering a few concessions would encourage them to establish kolkhozy in the Soviet countryside. For example, the government agreed to transfer tracts of state land to a number of sectarian groups for the purpose of building communal farms, and it gave part-time, unpaid sectarian ministers the right to own land. Mennonites were also allowed to hold church services and Bible studies, perform baptisms and other religious rites, and publish periodicals, albeit in an increasingly anti-religious environment. The regime even permitted an alternative military service program for Mennonites and other conscientious objectors. As a result of these measures, sectarian congregations did not experience the same kind of persecution as the Orthodox Church did in the early 1920s. ${ }^{12}$

Mennonite communities soon realized that it was in their best interest to foster a better relationship with the new Soviet regime. To this end, they organized the Verband der Bürger Holländischer Herkunft (Union of Citizens of Dutch Lineage or $\mathrm{VBHH}$ ), a semi-autonomous economic association that represented Mennonite economic, political, cultural, social, and religious interests in Ukraine. Recognized by Ukrainian authorities in 1922, the VBHH undertook a series of initiatives that included providing assistance in the agricultural and economic reconstruction of war-torn Ukraine, seeking foreign capital to benefit local agricultural projects, and establishing credit agencies and consumer associations to rebuild Mennonite settlements and farms. The VBHH also helped to establish two Mennonite artels, Vpered and Nova Ukraïna, in southern Ukraine the mid 1920s. ${ }^{13}$ Although the VBHH enjoyed remarkable economic and agricultural success, the Ukrainian government ordered it to discontinue operations in 1926 and subsequently reorganized many VBHH organizations into Soviet cooperatives. Local authorities also transferred assets from liquidated VBHH agencies to government-sanctioned committees for mutual assistance for the poor, village associations for the common tillage of land, raǐon animal associations, and dairy, butter, and machine tractor associations in Mennonite settlements. All Mennonites employed at VBHH agencies lost their positions, but not all were treated the same way after their dismissal. A few VBHH leaders, such as Phillip A. Cornies, were eventually arrested and imprisoned or exiled, while the agency rehired many lower-level VBHH representatives in these newly reorganized Soviet agencies. ${ }^{14}$ A number of former VBHH organizations came under the supervision of the government's Koopsoyuzy (Union of Cooperative Societies) and Kolkhoztsentr (All-Union Center of Agricultural Collectives), which facilitated the collectivization of Mennonite communities in the late 1920s and early 1930s. 
The new Soviet nationalities policy, announced in 1923, also proved to be an important factor in the establishment of kolkhozy in Mennonite settlements. Commonly referred to as korenizatsiia, this policy granted every Soviet national group its own national territory ranging in size from republics and oblasti (provinces) to raînn, national soviets, and kolkhozy. The policy also encouraged each national group to use its own language in government institutions within the group's territory, to celebrate acceptable forms of cultural expression, and to recruit and promote members of the national group into the Communist Party and leadership positions in village soviets and government agencies in the national territory. ${ }^{15}$ Korenizatsiia led to the organization of nine German national ralony in Ukraine in the 1920s, with several set aside for Mennonite communities. One was the Molochansk German national raion. Established in 1924, the Molochansk raĭon included 136 settlements (59 Mennonite villages) and encompassed 174,910 hectares (142,300 cultivated hectares). It had a population of 47,300 people by 1933 , of which 30,100 (64.8 percent) were German (including Mennonites) and 10,400 (22.3 percent) were Ukrainian. ${ }^{16}$ Another Mennonite-populated national raĭon was Khortytsia which was formally recognized in 1929. Smaller than Molochansk, the Khortytsia raion consisted of 38 villages (including 18 Mennonite settlements), 44,700 hectares of land and a population of 19,750 people (12,365 Mennonites and Germans, 6,569 Ukrainians, 530 Russians, and 286 Jews). ${ }^{17}$

As was the case in other national răony, individuals living in the Molochansk and Khortytsia national raǐony were categorized according to their social classbyvshie, kulak, seredniak, bedniak, batrak or worker - as well as their ethnic-national background (German, Ukrainian, Russian, Jewish, etc.). This Soviet version of affirmative action gave priority to Mennonites and ethnic German residentsespecially if they were bedniaki or batraki-for positions in government agencies in the German national raĭony. ${ }^{18}$ Mennonites were soon working for the Soviet state in increasing numbers, giving them greater control over the political, economic, agricultural, social, and cultural institutions in their settlements, not unlike the leadership roles they played in their communities under the Russian tsars.

The Soviet war scare of 1926-27 marked a turning point for the Mennonite communities in Ukraine. In late 1926, wild rumors began circulating around the country that Western powers were planning to invade the USSR. Fearing that the Soviet government would initiate widespread forced grain requisitions, peasants began hoarding grain, causing grain sales to the state to plummet. Although the rumors were unfounded, the Stalinist faction in the Soviet leadership characterized the war scare and the decline in peasant grain sales as a national crisis that threatened the 
country's ambitious industrialization program. The Soviet government implemented repressive administrative measures across the country to ensure the regular delivery of peasant grain to the state, ostensibly to ensure a continuous supply of grain to finance Soviet industrialization and feed the population should the country come under attack. ${ }^{19}$

The government first introduced administrative measures in early 1928 when it implemented new taxes and forced grain procurements to extract money and grain from the countryside. Initially these measures targeted kulaks and byvshie, but soon they affected seredniaki, bedniaki and batraki as well. The government also ordered the OGPU (state political police) to arrest private grain traders and kulaks, which heightened the terror in the countryside. ${ }^{20}$ Government repression against the kulaks intensified in 1929 and 1930, especially after Stalin announced in late December 1929 that the nation's kulaks must be "liquidated as a class." ${ }^{21} \mathrm{By}$ this time the government's "dekulakization" policy - a campaign to disenfranchise, dispossess, imprison, exile and in some cases execute kulaks - was well under way. The impact of these repressive measures on the Soviet peasantry was devastating: by the end of 1931, they had exiled more 1.8 million kulaks and state enemies to special settlements in northern and eastern Soviet territories. ${ }^{22}$

For a variety of reasons the dekulakization campaign was particularly severe in the Mennonite settlements in Ukraine. First, Mennonites generally had larger landholdings than their non-Mennonite neighbors as a result of special concessions obtained by the VBHH in the early 1920s. It was not unusual for a Mennonite family to own between fifteen and thirty-two desiatin of land, and to rent an additional five to ten desiatin - an amount that was larger than most Ukrainian peasant farms and which made Mennonites easy targets as "kulaks". A second reason why Mennonites were routinely included on kulak lists was because of their past opposition to the Bolshevik regime. Mennonites were often identified as enemies of the state because of their support of the German occupation forces during the First World War, the activities of Mennonite Selbstschutz units against the Red Army during the civil war, and the VBHH demands for special concessions during the early 1920s. A third factor related to the increasingly anti-sectarian attitude of the Bolshevik leadership. In a secret decree of 30 January 1930, for example, the Politburo identified sectarian communities, religious associations, and church councils as bases of support for kulaks and anti-soviet elements; the result was that dekulakization was often more repressive in sectarian communities, including Mennonite villages. A fourth factor was rooted in ethnic hostility: anti-German sentiment thrived at almost every level of the government, notwithstanding the government's nationality policies -7 -

The Carl Beck Papers in Russian and East European Studies http://carlbeckpapers.pitt.edu | DOI 10.5195/cbp.2015.199 | Number 2305 
in its korenizatsiia program. In Khortytsia, for example, local officials frequently accused Mennonite settlements of being "German nests of kulak opposition." A fifth reason for higher Mennonite dekulakization rates had to do with the ethnic and religious cohesiveness that existed in Mennonite communities. Authorities found this unacceptable, and they dekulakized Mennonite religious and economic leaders in the hope that this would dissolve community unity, ignite class warfare in the villages, and persuade more poor Mennonites to join the newly established kolkhozy. Finally, the authorities used dekulakization as a means to punish Mennonites for their past emigration activities. Mennonite efforts to emigrate were especially intense in the fall of 1929, when more than 9,000 Mennonites from across the USSR travelled to Moscow to obtain exit permits. Their story made international headlines and embarrassed the Soviet government into issuing exit visas to nearly 3,900 Mennonites. Authorities, however, denied more than 5,200 Mennonites permission to leave the country; instead many of the Mennonite men were imprisoned and eventually exiled while their families were loaded onto unheated rail cars and transported back to their settlements where they were often dekulakized within months of arriving home. ${ }^{23}$

The combination of these factors resulted in particularly high dekulakization rates in Khortytsia and Molochansk. In late February 1930, for instance, the Khortytsia Raŭispolkom (Raĭon Executive Committee or REC) passed resolutions confirming the dekulakization of eighty-three households, of which no fewer than seventy-nine were Mennonite; these tallies do not include the Mennonite kulaks arrested by the OGPU during this time. Although Mennonites and Germans made up only 63 percent of the population in Khortytsia, more than 96 percent of those dekulakized in the raîn in 1930 were Mennonite. High dekulakization rates were just as prevalent in Molochansk. According to a secret party document prepared in 1935 , more than five hundred households were dekulakized in the eastern villages of the Molochansk district (later known as the Rot-Front [Red Front] raǐon) in 1929-31. It is not known exactly how many Mennonite households were dekulakized from the western villages in Molochansk during this time. ${ }^{24}$

Dekulakization created widespread terror in the countryside, driving peasants into kolkhozy and sovkhozy (state farms) en masse. As 1929 drew to a close, Stalin boasted that entire villages and districts of peasants were flocking to kolkhozy. To accelerate the collectivization process, the Central Committee dispatched OGPU officials and the "25,000ers" - more than 27,000 factory workers, party members, Red Army soldiers, and Komsomol members recruited to help establish kolkhozy throughout Russia - to penetrate the countryside and do whatever was required to 
compel more bedniaki and seredniaki to join the kolkhozy. ${ }^{25}$ All of these efforts resulted in spectacular collectivization statistics: at the beginning of March 1930, for example, the government reported that 52.7 percent of all Soviet households and 60.8 percent of peasants in Ukraine were in kolkhozy. But these impressive percentages belied the disorganization and chaos that pervaded most newly established kolkhozy. In reality, the vast majority of kolkhozy lacked adequate resources and leadership to function properly. ${ }^{26}$ In an effort to resolve these issues, the government established Narkomzem (People's Commissariat of Agriculture) and Kolkhoztsentr (All-Union Center of Agricultural Collectives) to supervise the organization and operation of kolkhozy.

The government also decided to permit three different types of kolkhozy in the countryside: the commune, the artel, and the association for joint cultivation of land (commonly referred to as "TOZ" or "SOZ"). The organizational structure and operation of communes, artels, and TOZy varied from one region to another, but the main difference between them was the degree to which the means of production in each type of kolkhoz was socialized. The commune was seen as the highest form of socialist production. The kolkhozniki (kolkhoz members) worked all the land in the commune collectively; all animals, machinery, and farm buildings were owned in common, and commune members often shared living quarters and ate their meals together. In the artel, each household was entitled to keep a small plot of land for personal use, but the remaining arable land was held and worked in common. The draught animals and agricultural implements were owned collectively, but each individual artel household was allowed to have a small agricultural enterprise, such as an egg operation, for personal use. The government viewed the TOZ as the lowest form of socialist production. The land in a TOZ was worked in common by all kolkhozniki and most of the larger agricultural equipment was owned collectively, but all the animals and most of the smaller agricultural implements remained in the personal possession of the individual members. In January 1930, the Central Committee confirmed that the artel would serve as the most common form of kolkhoz for the foreseeable future. ${ }^{27}$

In February 1930, just as the dekulakization and collectivization campaigns were reaching maniacal speed, the Soviet leadership began to question the pace of these campaigns and feared they might have disastrous consequences for the upcoming crop year. This resulted in a change in government policy that culminated in Stalin's article entitled "Dizzy with Success." Appearing in Pravda on 2 March 1930, Stalin's article recognized the great accomplishments that the country had made during collectivization, but it also chided local party and government officials 
for using excessive force in their dekulakization efforts, thereby endangering collectivization. ${ }^{28}$ The publication of this article resulted in celebrations and riots in the countryside, with many peasants interpreting Stalin's comments as permission to leave the kolkhozy. Within weeks, eight million households quit the collectives and returned to their farms taking with them some seven million draft animals. The national collectivization rate plummeted to 37.3 percent by April 1930, demonstrating that many kolkhozy were nothing more than "paper collectives" with little peasant support. ${ }^{29}$

"Dizzy with Success" signaled the government's retreat from, but not abandonment of, its collectivization objectives. In fact, the regime initiated a new collectivization drive in the late summer of 1930. The Soviet leadership also announced that all kolkhozy were required to deliver their tractors and farm machinery to the newly established Machine Tractor Stations (MTS), which would now provide tractor and other mechanical services to kolkhozy. To ensure that this latest collectivization drive did not lose momentum, Kolkhoztsentr dispatched a new shock force - the "20,000ers" - into the countryside in December 1930. The 20,000 ers were experienced collective farmers ordered to spur on collectivization efforts in more "backward" villages. Their efforts proved very successful: by May 1931, the total number of collectivized households reached 12.5 million (50.4 percent). This second collectivization drive continued until late 1931, when Kolkhoztsentr reported that an overwhelming majority of districts in the country were collectivized. ${ }^{30}$

The regime's collectivization campaign in Khortytsia and Molochansk was swift and harsh. The collectivization there was heavily dependent on hundreds of Khortytsia and Molochansk Mennonites who, through the korenizatsiia program, were now serving in local government posts. A large percentage of these Mennonites worked in the village soviets. ${ }^{31}$ Mennonites also joined and assumed leadership of village potrebsouizy (consumer associations), kombedy (Committees of the Village Poor or CVP) and Raboche-krest'ianskaia inspektsiia (Workers and Peasants Inspection Committees or WPIC). ${ }^{32}$ Influential Mennonites also served on the REC (Raĭon Executive Committee) and the Raĭpartkom (Raĭon Party Committee or RPC), the two organizations that coordinated the dekulakization and collectivization of the Khortytsia and Molochansk national raǐony. Heinrich G. Rempel, for example, was a Mennonite communist party member who served as chairman of the Khortytsia REC from 1928 to January 1930, and administered collectivization and dekulakization policies during this period. Another Mennonite communist party member, Johann P. Quiring, served as Khortytsia REC chairman from January 1930 until late June 1930. 
He oversaw some of the harshest dekulakization campaigns in the area and facilitated the collectivization of much of the raĩon during his short tenure. ${ }^{33}$ There were even several Molochansk Mennonite communists who served with the OGPU and later the NKVD (political police). ${ }^{34}$ Mennonites also played key roles in the following important government agencies: the MTS; the People's Court; the Raǐzemotdel (Raĭon Land Division Committee), which oversaw all agricultural activity in the raîon, including the creation of collective farms; the Ralkoopzerno (Raǐon Grain Association), which supervised grain production in the raĭon; the Raĭposevtroika (Raĭon Seeding Troika); the Raǐsel'bank (Raĭon Village Bank); the Raĭtorgotdel (Raĭon Market Commission); the Raǐkolkhozzernosoiuz (Raĭon Kolkhoz Grain Union); and the Raĭmetodburo (Raĭon Methodical Office), which was responsible for the school curriculum, the hiring and firing of teachers, the operation of local Pioneer organizations, the creation of Bauernheime (peasant clubs) and Lesenhallen (reading rooms), as well as the development of antireligious educational programs ${ }^{35}$

As agents of the state, Mennonite officials carried out the unpleasant tasks of dekulakizing and collectivizing their own communities in Khortytsia and Molochansk, thereby undermining the authority of traditional Mennonite institutions. These Mennonite officials also gave legitimacy to the state-sponsored violence against Mennonite villages and worked to convince fellow Mennonites that joining a kolkhoz was the best way to avoid dekulakization and exile. The arrest and exile of hundreds of Mennonite religious, civic, and economic leaders created panic and confusion in Mennonite villages, destabilizing the communities and making it easier for local authorities to convince poorer Mennonite peasants that Soviet authority, not the traditional Mennonite leadership, now controlled the political, economic, and social agenda in Mennonite villages. Officials eventually began targeting seredniak, batrak, and bedniak Mennonite households for dekulakization, often branding them as podkulachniki (kulak hirelings or agents). By early 1931, almost every Mennonite village in Khortytsia and Molochansk witnessed the arrest and exile of Mennonite families in these categories. In short, dekulakization triggered the disintegration of the traditional economic, religious, and social hierarchies that had governed Mennonite settlements for more than a century, thereby facilitating the speedy conversion of Mennonite settlements into Soviet kolkhozy. ${ }^{36}$

This is not to say that local officials viewed Mennonite villages as easy targets for their collectivization plans. In late January and early February of 1930, for example, regional authorities in Zaporizhia held a series of meetings during which they acknowledged that the Mennonite/German communities of Khortytsia provided the strongest opposition to collectivization in the region and that more administrative

The Carl Beck Papers in Russian and East European Studies http://carlbeckpapers.pitt.edu | DOI 10.5195/cbp.2015.199 | Number 2305 
measures would be necessary to break this German resistance. They also determined that it would be beneficial to host a public meeting for "able-bodied German peasant farmers" on 15-16 February 1930 to explain the benefits of kolkhoz life. At the session, officials quickly identified the kulak problem in the German villages as especially bad. They declared that "those who served in the religious cults were the helpers of the kulaks," and that "all energy must be used to liquidate the kulak as a class, especially in the German villages where all of their inventory and economic work must be used for the benefit of bedniaki and seredniaki." The message from these officials was clear: those Mennonites who did not join a kolkhoz would be dekulakized and all Mennonite property would be expropriated for the benefit of the state. This prompted Mennonite and German peasants to ask officials a host of questions, some of which revealed their concern about how officials planned to treat kolkhozy with only Mennonites and Germans versus those kolkhozy with ethnically diverse populations. For example, would they organize a village of German and non-German residents into one national kolkhoz or into two separate kolkhozy based on ethnicity? If a village were "half-German and half-Russian," would it be permissible for the German farmers to join a German kolkhoz in a neighboring German village? Would the government treat German kolkhozy differently than non-German kolkhozy? Which national minorities were the most resistant to the collective farm movement? ${ }^{37}$ It was clear from these questions that Khortytsia Mennonites and Germans were worried about potential ethnic conflict in mixed German and non-German kolkhozy, and that local authorities would treat German kolkhozy more harshly than other ethnic groups.

Despite Mennonite resistance, local officials were able to collectivize Khortytsia and Molochansk in relatively short order, at least as it appeared on paper. In 1927, for example, there were only two communities (Khortytsia and Kandrovka) in the Khortytsia area with a kolkhoz, but there were a growing number of zemobschestva (land associations), many of which were already established in 1924-5 and had Mennonite members and leadership. ${ }^{38}$ In 1928, some of these zemobschestva were purged of their kulak elements and reconstituted with new incorporation statutes. In July 1928, Mennonites in the Khortytsia village of Blumengart established an allMennonite land association with an all-Mennonite executive and audit commission. Six Mennonite families wanted to join the new association but were barred from doing so after local officials labelled them as lishenetz (disenfranchised) because of their kulak background. In other Mennonite settlements, the zemobschestvo were organized into artels, such as the Druzhba artel that was established in Schönhorst, Khortytsia in May 1928. By spring 1930, however, most of the Mennonite 
zemobschestva were liquidated and their assets transferred to the newly established kolkhozy. By the summer of 1930, there were at least thirty-four kolkhozy in Khortytsia răon: three communes, nineteen artels and twelve SOZy. Of the 3,822 households in the raĭon, 2,482 (64.9 percent) were in kolkhozy: 239 households were in the communes, 1,445 in artels, and 798 in SOZy. By this time, every Mennonite community in Khortytsia had least one kolkhoz, and some communities, such as Khortytsia, Neuendorf, Schöneberg, Einlage, Osterwick, and Nikolaipol, had two or three kolkhozy. By the end of 1930, 40,380 hectares-almost 100 percent of the land in the raion-was collectivized. Some of the Mennonites recognized for playing an important role in organizing kolkhozy in early 1930 included A. Braun (Eisenfeld), Rempel at Internatsional SOZ (Nieder-Khortytsia), J. K. Klassen at Rekord SOZ (Nieder-Khortytsia), P. P. Giesbrecht at Landmann SOZ (Neuendorf), Krieger at Progress, and J. Tiessen (Burwalde). ${ }^{39}$

The collectivization of Molochansk bore similarities to what had occurred in Khortytsia. An increasing number of zemobschestva began appearing in the raion in 1927, and by 1928 Mennonites were serving as chairmen of newly established Molochansk land associations ${ }^{40}$ Following the intensification of dekulakization in 1929, Molochansk officials proudly reported in early 1930 that 92 percent of the households and 93 percent of the land in the raion had been collectivized. By the end of 1930, raĭon reports indicated that 90 percent of all bedniak and seredniak households and 92 percent of all bedniaki and seredniak land was now under kolkhozy control. The raǐon now had 127 kolkhozy, of which ninety-six were artels and thirty-one were SOZy; there was also a commune, fourteen dairy fermy (farm units), seventeen swine fermy, and several cattle associations..$^{41}$ The raĭon kolkhozy also increased their landholdings by 80 percent, from 63,470 hectares in 1930 to 116,250 hectares in 1931. Germans and Mennonites constituted 65 percent of the entire kolkhoz population in the raĭon, Ukrainians 22.3 percent, and Russians 6.5 percent. Some kolkhozy in both Molochansk and Khortytsia were exclusively Mennonite; in early 1930, for instance, the Forwerts SOZ in Neuendorf, Khortytsia, had eighteen families (twenty men, eighteen women and forty-two children), all of whom were Mennonite. A few Molochansk kolkhozy were composed exclusively of Ukrainians, but most consisted of a mixture of Germans, Mennonites, Ukrainians, Russians, and Jews. ${ }^{42}$ 


\section{The Administrative Structure of Khortytsia and Molochansk Kolkhozy}

Most Mennonite peasants who joined the Khortytsia and Molochansk kolkhozy in the late 1920s had little idea as to how to administer the kolkhozy, and had no choice but to rely on the advice of local officials who had never been formally trained in such matters. Some administrative direction was provided in the governmentissued kolkhoz incorporation statute, a document signed by peasants shortly after they voted to organize a new kolkhoz in their community. In the Khortytsia and Molochansk raĭony, one of the most commonly used incorporation statutes was a thirty-four page, fill-in-the-blank document in the German language that detailed government directives for incorporating and operating artels. ${ }^{43}$ Among other things, the statute included government-prescribed objects and bylaws that applied to the administration and day-to-day operations of the kolkhoz. The statute made it clear that every artel was a separate legal entity with its own rights and privileges, including the right to hold an interest in land and to act as the plaintiff or defendant in legal proceedings. The statute also stipulated that the leading organ of the artel was the kolkhoz general assembly, where only kolkhozniki in good standing were allowed to vote on general assembly matters. The statute gave the general assembly the mandate to deal with matters such as the election and removal of members in the kolkhoz administration, proposals of the kolkhoz administration, the acceptance of new kolkhozniki into the artel, and the expulsion of kolkhozniki who violated kolkhoz rules. ${ }^{44}$ The statute also provided guidelines for extraordinary meetings of the general kolkhoz assembly, quorum and procedural rules for kolkhoz meetings, the authority of the general kolkhoz assembly over the kolkhoz chairman and administration, and directions for dissolving an artel.

While the incorporation statute guaranteed equal rights and privileges for all kolkhozniki, in reality this was rarely the case. Tightly stratified hierarchies developed in kolkhozy almost immediately after their incorporation, with the chairman and the kolkhoz administration at the top of the pecking order; brigadiers, school teachers and skilled farm workers in the middle; and unskilled farm laborers, the elderly, and the infirm at the bottom.

The incorporation statute provided newly elected artel chairmen with important guidance for organizing the artel administration and running the day-to-day affairs of the kolkhoz. For example, the statute directed that two administrative bodies were to govern the kolkhoz: the executive council, which in principle was to take its directions from the kolkhoz general assembly; and the audit commission, which reviewed the 
decisions and directives of the executive council and provided periodic evaluations concerning the performance of the kolkhoz, the kolkhoz chairman, and the executive council. The statute also provided directives concerning the composition, size and duties of the executive council and the audit commission. For example, kolkhozniki were not allowed to serve on the executive council and the audit commission at the same time; individuals on the executive council and audit commission could not be related to one another by blood or marriage; the executive council had to have at least five members and two candidate members elected by the general kolkhoz assembly; members of the executive council had to elect the kolkhoz chairman from among themselves; the term on the executive council was one year; and the kolkhoz general assembly could recall executive and audit commission members at its discretion. Finally, the statute directed that members of the executive council and audit commission were to participate in the kolkhoz general assembly, but had to recuse themselves from decisions involving any of the following issues: an audit of the kolkhoz administration; a judgment against the conduct of the executive council, audit commission or members thereof; and matters dealing with the liability of a member on the executive council or audit commission. ${ }^{45}$

With the incorporation statute in hand, Khortytsia and Molochansk Mennonites clumsily but quickly organized their village kolkhozy. On 1 February 1930, for example, thirty-seven individuals (thirty-five Mennonites and two non-Mennonite Germans) from the Rosengart (Khortytsia) area met at the hastily called inaugural meeting of the Pachar artel. Despite the small number of villagers present at this meeting, those in charge directed the participants to pass a number of important resolutions, including motions to incorporate the Pachar artel, actively campaign for new members to join the artel, complete the required government paperwork to register the artel, and ensure that no kulaks or ekspertniki were permitted to join or infiltrate the newly established kolkhoz. The members also elected Kornelius Braun, a Mennonite, as interim chairman of Pachar at this inaugural session. A week later, after local authorities had ramped up dekulakization measures in the area and publicly identified a number of Mennonite families as kulak and ekspertnik households, attendance at the second meeting of the Pachar artel on 7 February had greatly improved. By then, fifty-four Mennonite families and two non-Mennonite German families had joined Pachar, including sixty-seven men and seventy-three women who were deemed "able to work," thirteen men and fourteen women who were characterized as "unable to work," and 118 children. These 56 families had transferred 858 hectares of land, three cows, four calves, four sheep, 520 poultry, seven threshing machines, seven winnowing machines, thirteen seed drills, nine ploughs,

The Carl Beck Papers in Russian and East European Studies http://carlbeckpapers.pitt.edu | DOI 10.5195/cbp.2015.199 | Number 2305 
and fourteen buggies to Pachar. At the 7 February meeting the members elected an all-Mennonite executive council with five members (including the Mennonite Peter A. Hamm as chairman) and two candidate members, and a predominantly Mennonite audit commission (three Mennonite members, one Mennonite candidate member and one non-Mennonite German candidate member). By the end of February, after local village soviets had passed resolutions to dekulakize three Mennonite families from the Rosengart-Burwalde area and eighteen Mennonite families from the nearby village of Osterwick, more than 95 percent of the non-dekulakized households in Rosengart had joined Pachar. ${ }^{46}$

The executive councils at the Khortytsia and Molochansk kolkhozy usually included the kolkhoz chairman, a secretary, an accountant or bookkeeper, and an economist/field manager. Some kolkhozy also included political commissars and brigadiers (supervisors of the kolkhoz work brigades) on their executive councils. It was not uncommon for Mennonites to hold most, if not all of the positions on the executive council. When the Dniprostrol Association for the Common Tillage of Soil was organized in Einlage (Khortytsia) in January 1930, for example, Mennonites filled the five positions of the executive: A. A. Thiessen as chairman, A. J. Martens as secretary, P. A. Martens as bookkeeper, P. A. Peters as economist manager, and J. J. Plänert as assistant to the economist manager. The initial term of office for peasants elected to the position of chairman at the organizing meetings of their kolkhozy was often very short - a few days or weeks - as this novice chairman generally served on an interim basis until a permanent chairman was elected. Local officials often wanted to control who was appointed chairman, especially when they had their own vetted candidate ready to step into the position or when the first chairman repeatedly failed to meet their expectations. It was not uncommon for chairmen in newly organized kolkhozy to feign illness or quit their positions when they realized that they were not up to the task. A chairman could also be recalled by the kolkhoz membership if he no longer had the confidence of the kolkhoz rank and file; the REC made recall elections difficult, however, requiring that a chairman serve at least one year and that the REC approve the recall election. If the kolkhoz membership wanted a speedier remedy to remove their chairman, they could ask the REC and village soviet to replace the chairman immediately because he was a kulak, ekspertnik, byvshie, lishenetz, former supporter of the White Army, former member of the Mennonite Selbstschutz, or because he held strong religious convictions. The publication of Stalin's article "Dizzy with Success" in March 1930 also initiated a high turnover of kolkhoz chairmen, as it convinced both Mennonite kolkhozniki and kolkhoz chairmen that they had the government's permission to 
quit the kolkhozy. At a meeting of the Khortytsia REC in June 1930, for example, officials acknowledged that German peasants - including Mennonites - and former kolkhoz chairmen were reluctant to rejoin the kolkhozy and that German peasants continued to oppose mass collectivization. The solution to this problem was simple: harsher administrative measures (including grain procurement campaigns) had to be implemented in the German settlements to convince the German peasants to participate in collectivization. ${ }^{47}$

What qualities were important to consider when selecting a chairman? The incorporation statute listed several requirements for the position. One was that only enfranchised individuals eighteen years of age or older could be elected. Another was that a kolkhoz chairman could not be related to another member of the executive council or audit commission by blood or marriage, though kolkhoz members often turned a blind eye to such breaches of the statute. Ironically, farming experience and past agricultural success were not statutory requirements, and appear to have had little, if any bearing on the election of many chairmen. The Mennonite David J. Braun, for example, was the twenty-four-year-old son of a factory worker when he was elected chairman of the Altonau kolkhoz (Molochansk) in 1931. Braun did not have any farming experience to speak of, but his membership in the Komsomol (since 1928), his past service in the Red Army (1928-30) and the People's Court, his involvement in the Münsterberg village soviet, and his acceptance as a candidate for party membership in 1931 made up for his lack of practical experience. Educational and professional qualifications were also not considered essential; in fact, illiterate and semi-literate individuals were occasionally appointed to the chairman's post. Being illiterate did not necessarily pose a major problem so long as the kolkhoz secretary who handled the kolkhoz paperwork could read and write. ${ }^{48}$

The criteria for kolkhoz chairmen were not defined solely by the incorporation statute. There were also unwritten government expectations that had to be adhered to. Social class, for instance, was an important consideration. Mennonites with unacceptable social pedigrees - kulaks, bourgeois, ekspertniki, lishentsy, byvshie, and religious leaders - were automatically disqualified. Despite this prohibition, some class enemies were still able to manoeuvre themselves into the post of chairman and operate until their past identities were discovered. The Mennonite chairman of the Einlage artel (Khortytsia), Neufeld, acknowledged that in the early 1930s, many of the Khortytsia kolkhozy were managed by Mennonite kulaks. Those from "sociallyfriendly classes"- bedniaki, batraki, and workers - were often considered to be prime candidates for the post, even if they lacked leadership experience or farming success. In the early years of collectivization, a few Mennonites from the "socially- 
neutral" class of seredniaki were also elected as chairmen, but this occurred less frequently as time progressed. Ethnicity was another important factor. Mennonites and ethnic Germans from "socially-friendly" classes were more likely to secure the post of kolkhoz chairman in Mennonite-populated kolkhozy in the late 1920s. ${ }^{49} \mathrm{By}$ 1931-32, however, an increasing number of non-Mennonites were elected to manage Mennonite-populated kolkhozy. In many elections for the position of chairman, it appears that the correct social pedigree and ethnic background trumped superior agricultural expertise or educational qualifications.

Demonstrations of loyalty to the regime, connections to the party, and past meritorious service to the state were also important considerations when vetting candidates for the post of kolkhoz chairman. For instance, at least five Mennonite communists in the Molochansk raĭon used their party affiliations to become kolkhoz chairmen: Nikolai Boldt (party member) served as kolkhoz chairman at Hierschau, David J. Braun (party candidate) at Altonau, David K. Unruh (party candidate) at Nadezhda (Ohrloff), Jakob J. Regier (party candidate) at Gnadenthal, and Schmidt (party candidate) at Mariawohl. Party membership, however, was not a requirement for the position. Anyone who worked for a local village soviet, CVP, WPIC, government agency, or as a kolkhoz secretary or bookkeeper generally had an advantage over candidates with no past record of service to the state or kolkhoz..$^{50}$

Some unspoken but critical factors that influenced the selection of a kolkhoz chairman included religiosity, sectarianism, and gender. Individuals who were known to hold strong religious beliefs or who had previously held leadership positions in Mennonite congregations were immediately deemed ineligible for the position of kolkhoz chairman. The regime's anti-sectarian policies also disqualified those who had served in Mennonite organizations such as the VBHH. ${ }^{51}$ Mennonite women were also not elected to the post of kolkhoz chairman, notwithstanding the fact that the incorporation statute clearly stated that all positions in the kolkhoz were open to women. The reality was that female Mennonite candidates could not shatter the glass ceiling of kolkhoz chairmanship, in spite of Bolshevik claims that their policies promoted the equality of the sexes. 


\section{The Duties of the Kolkhoz Chairman}

Under enormous government pressure to get their newly incorporated kolkhozy up and running, novice kolkhoz chairmen had little time to celebrate their recent appointment. The regime initially provided few training programs or instructional materials for chairmen; most learned their new responsibilities on the job. One of the most important lessons a chairman had to learn was that his first duty was not to the kolkhoz and its general assembly as stated in the incorporation statute, but to his political superiors and the Soviet regime. The priorities and policies of local officials and the regime always came first, even if they were unsound, misleading, incoherent, reprehensible, or contrary to the interests of the kolkhoz and its members. Kolkhoz chairmen also had to learn how to decipher and speak the regime's "doublespeak": chairmen had to parrot, promote, and defend government propaganda and policies, even when they were a distortion of reality and imperilled the lives of those living in the kolkhoz.

The ability to prioritize and implement the barrage of government policies and directives that arrived at the kolkhozy on an almost daily basis was another important survival skill for kolkhoz chairmen. These policies and directives came from various levels of the regime, including the Kremlin; the offices of Sovnarkom (Council of People's Commissars) and Kolkhoztsentr; the Ukrainian republic; and regional government and party offices. They were usually in the form of all-Union, all-Republic, or regional directives published in Pravda. These directives announced new national and regional agricultural policies and procurement campaigns, together with impossible deadlines for seeding, ploughing, harvesting, and delivering agricultural produce. Most day-to-day directives, however, came in the form of paper memos from the offices of the REC, local village soviet, and government agencies such as the MTS and WPIC. Orders from the REC and village soviets addressed almost every aspect of kolkhoz life, including economic, agricultural, educational, and cultural policies for kolkhozy in the raĭon. Agricultural policies, for example, included prescribed schedules for ploughing, sowing, weeding, and harvesting, as well as deadlines for the collection of tax assessments and state obligations owed by each kolkhoz. For many kolkhoz chairmen, the most dreaded REC and village soviet directives dealt with government procurement contracts. Local authorities in Khortytsia and Molochansk unilaterally drafted procurement contracts that required each kolkhoz to deliver a wide range of agricultural products to the state: grain (including wheat, rye, oats, barley, millet and corn), sugar beets, root crops 
(potatoes, carrots, etc.), sunflower seeds, livestock fodder, livestock, meat (beef, pork and lamb), milk, butter, cheese, eggs, animal hides (cow, horse, sheep, ground squirrel and rodent), animal bristle, horse hair, animal bones, horns, hooves, leather (pig, sheep, goat, cat, and dog), wool, feather down, and ash fertilizer. Procurement contracts typically required kolkhozy to deliver products to government facilities on a weekly, monthly or yearly basis. Dairy and egg quotas, for example, were usually delivered weekly; grain and meat monthly, trimonthly or quarterly; and root crops and sunflower seeds yearly. To ensure compliance with the contracts and delivery schedules, government authorities routinely issued scathing directives warning kolkhoz chairmen that they would be held criminally responsible for any shortfalls in meeting the procurement contracts. At Friedensruhe (Molochansk), for example, members of the Stern kolkhoz were only able to deliver 4,000 poods of grain to the state in late 1931, falling far short of the government quota of 24,000 poods of wheat, 600 poods of rye, 500 poods of sunflower seeds, and 90 poods of pumpkin seeds. Predictably, local authorities threatened the kolkhoz chairman and members with immediate arrest if they failed to deliver enough grain from their own reserves to make up the shortfall. ${ }^{52}$

If the first duty of a kolkhoz chairman was to his political superiors, the state and its agencies, then his second duty was to the kolkhoz as a legal and economic entity, as distinct from the kolkhozniki. In fulfilling this duty, the kolkhoz chairman had to be able to make a distinction between the interests of the kolkhoz and those of the membership; it was the state that determined the interests of the kolkhoz, and as any astute chairman soon discovered, they were often not the same as the interests of the membership. If there was a conflict between the two, it was the responsibility of the chairman to ensure that the interests of the kolkhoz took priority. For example, Mennonite chairmen and their administrations generally made kolkhoz grain and meat for state procurement contracts and obligations a top priority. If and when chairmen met state quotas, kolkhoz grain was then used to fill the seed and grain reserve funds of the kolkhoz, as well as fodder reserves. If there was not enough grain and meat to satisfy state procurement obligations, the chairman saw to it that resolutions were passed ordering the kolkhozniki to return some or all of their food rations to make up the shortfall. If a shortfall persisted, the chairman could order house-to-house searches for hidden grain and meat. ${ }^{53}$ While kolkhoz chairmen often declared that their foremost concern was the well-being of the kolkhoz members, their actions indicated otherwise.

Lower on the chairman's hierarchy of duties were his responsibilities to the kolkhoz general assembly and kolkhoz members. The incorporation statute 
stipulated that the chairman was to carry out his responsibilities with the consent and approval of the kolkhoz general assembly. The practical realities of managing a kolkhoz, however, did not always make this possible or desirable. Kolkhoz chairmen routinely made decisions unilaterally or after consulting only with the members of the executive; sometimes it was easier or more expedient for the chairman to ask for the assembly's forgiveness than for its permission.

The incorporation statute also outlined specific duties that the chairman and his executive council were expected to fulfill on behalf of the assembly. Some of the administrative duties included ensuring that the incorporation statute and other documentation from the inaugural meeting was completed, signed and filed with the raîon soviet; directing the work of the kolkhoz according to the provisions of the incorporation statute and the decisions of the kolkhoz general assembly; developing and implementing a plan for the cultural and intellectual enlightenment of kolkhoz members; and representing the kolkhoz in all matters, including all dealings with kolkhozniki and government institutions. There were also financial and fiduciary responsibilities, some of which included the following: developing an agricultural production plan for the kolkhoz and supervising its economic and non-economic affairs; preparing and implementing the budget for the annual report and production plan, and obtaining any necessary loans and credit; purchasing and selling kolkhoz inventory and produce; maintaining, repairing and insuring the assets of the kolkhoz; negotiating and executing all contracts, trade transactions, purchases, and undertakings on behalf of the assembly; managing the undivided capital assets of the kolkhoz; reporting to the assembly concerning the kolkhoz's agricultural and economic results for the past and current economic year; and addressing any concerns arising from the annual audit undertaken by the kolkhoz audit commission. ${ }^{54}$

In addition to the responsibilities prescribed by the incorporation statute, the kolkhoz chairman had a host of other, often unspoken duties to perform. Kolkhoz chairmen were also expected to volunteer at community agencies and institutions such as the local Red Cross, a school, or a hospital. Chairman A. Neufeld of the Tiege artel (Molochansk), for instance, served on the executive committee of the local Institute of the Deaf and Dumb in 1932. A chairman also had responsibilities to his family, but state authorities and the kolkhoz membership expected and often demanded that the chairman subordinate his familial obligations and personal interests to his duties to the kolkhoz, the larger community, and the country. ${ }^{55}$ It was common for local officials to reprimand or punish a kolkhoz chairman, often at a kolkhoz general assembly meeting, if the kolkhoz chairman behaved in a way 
that put his own interests or those of his family ahead of the interests of the state, the kolkhoz or the kolkhoz membership.

Balancing these conflicting duties was no easy task, especially for novice chairmen overwhelmed with a barrage of government orders and unrealistic deadlines. Inexperienced and lacking confidence, many novice chairmen made decisions and implemented policies in order to please their political masters rather than considering practical realities. The results were often disastrous, costly, and a source of frustration for the kolkhoz membership. Early on in the collectivization process, for example, government authorities put enormous pressure on kolkhoz chairmen to adopt communal housing policies in an effort to foster a stronger socialist attitude among kolkhozniki. Despite strong opposition from their members, Khortytsia and Molochansk chairmen implemented untried communal housing policies. In some kolkhozy, three or more families occupied a house vacated by a single kulak family; in other kolkhozy, families were shuffled from one hut to another every few months, even in the middle of winter. Almost every kolkhoz either dismantled well-built kulak and peasant homes to salvage the building materials or converted them into livestock stalls, milking parlours, grain bins, clubs, or reading halls in order to demonstrate their compliance with government directives. Some kolkhozniki at the Tiege artel in Molochansk had to pay a monthly rent of three rubles to the kolkhoz, while others were exempt from paying rent or had their rents reduced. ${ }^{56}$ Not suprisingly, many kolkhozniki refused to move into collectivized homes confiscated from dekulakized peasants, fearing that doing so would result in increased rents or accusations that they were kulaks or ekspertniki. Predictably, these communal housing policies incited widespread frustration, with kolkhozniki complaining to the chairmen that the new living arrangements were impractical, overcrowded, disruptive, and humiliating. Conflicting government rules concerning each kolkhoznik's personal ownership and use of land and livestock only exacerbated this frustration. At some kolkhozy, each household was allowed access to a small plot of land (usad'ba) and could keep a cow, a few pigs or some sheep for its personal use. At other kolkhozy, however, members were denied any personal use of a usad'ba or livestock. Still other kolkhozy permitted only selected households, such as those with young children or handicapped members, limited personal use of usad'ba and livestock. These restrictive and sometimes inconsistent policies incited hostility among kolkhozniki, with chairmen often bearing the brunt of their frustration. ${ }^{57}$

There were other occasions when the decisions of the Soviet leadership foiled the best efforts of kolkhoz chairmen to fulfill their duties to the state. For instance, the publication of "Dizzy with Success" in March 1930 initiated a massive departure of 
Mennonite and non-Mennonite peasants from Khortytsia and Molochansk kolkhozy. Many kolkhozy no longer had adequate manpower to complete their agricultural work, and some were forced to close down. ${ }^{58}$ The chairmen at those kolkhozy that continued to operate now faced enormous challenges, one of which was the redistribution of kolkhoz land. In late April 1930, Okrsernopilka (the Zaporizhia Regional Grain Cleaning Department) issued a complicated set of instructions to Khortytsia kolkhoz chairmen concerning the process of returning kolkhoz land to peasant households intent on leaving the kolkhoz. The instructions made it clear that the best land in the kolkhozy was to remain in the kolkhozy, regardless of who the previous owner had been. The departing households would only be entitled to receive an allotment of the worst land in the kolkhoz. If the land was fallow, the departing households could receive their land allotments immediately; if the kolkhozniki planted crops on the land, they would only receive their allotments after the kolkhoz had harvested the crops on it. Most departing households saw these instructions as unfair and vented their anger at their chairman. Complicating matters for the chairmen was the fact that instructions were issued at one of the busiest times in the agricultural year, forcing them to begin redistributing kolkhoz land to departing households at a time when they should have been devoting all of their efforts to the agricultural work of their kolkhozy. Most kolkhozy now found it impossible to complete their agricultural work and harvest because of the exodus of kolkhozniki. Only after the government began to reimplement repressive administrative measures in the late summer of 1930 did kolkhoz chairmen began to see their membership rolls increase..$^{59} \mathrm{By}$ this time, however, the opportunity to complete important fieldwork, such as sowing, weeding, and threshing, had passed.

Local officials impeded novice chairmen from fulfilling their duties in other ways. In 1929-30, for example, many REC and village soviets issued orders to kolkhozy to supply men for labor service on local road and construction projects. Raĭon military commissars also drafted eligible young men from the kolkhozy for military service in the Red Army or alternative service in the Tyl Opolcheniia ("TO"), which was the rear militia for socially-alien elements such as conscientious objectors, religious believers, and kulaks or ekspertniki. Most young Mennonite men born between 1908 and 1912 served in the TO in the early 1930s in onerous working conditions where injury and death were commonplace. Unlike Mennonites who had completed their service in the Red Army, Mennonite kolkhozniki who had served in the TO were periodically recalled for additional labor service. In Molochansk, for example, men born between 1901 and 1908 who had served in the TO, as well as men born between 1902 and 1908 who were exempt from military service 
because of religious convictions, were required to perform an additional one-year labor service commencing in July 1931 under Narkomtrud (National Commissariat of Labor). These unpredictable, ongoing state demands for young men siphoned valuable manpower from the kolkhozy, compounding the labor challenges facing kolkhoz chairmen. ${ }^{60}$

The government made life even more difficult for kolkhoz chairmen when it initiated another dekulakization campaign in early 1931, this time focusing on kulaks and ekspertniki who had infiltrated the kolkhozy. On 6 January 1931, Pravda published an article entitled "Sweep the Kulaks out of the Kolkhozy with an Iron Broom." In the weeks that followed, the government blamed kolkhoz chairmen, in part, for the kulak "infestation" problem, complaining that the chairmen had either been wilfully blind to their presence or had been duped into allowing the kulaks entry. The Politburo issued a decree on 20 February 1931 titled "Concerning the Kulaks" that directed the OGPU to establish 1,000 kulak settlements within six months to accommodate 200,000-300,000 families. The Politburo later reduced this quota to 110,000 families, and in June 1931 the OGPU exiled 101,184 families to remote areas of the country. ${ }^{61}$ This campaign could not have come at a worse time for kolkhoz chairmen: with such large numbers of kolkhozniki expelled from kolkhozy, completing the field work and fulfilling government procurement contracts seemed like a Sisyphian task.

\section{The Daily Routine of Kolkhoz Chairmen}

Molochansk and Khortytsia chairmen had to follow a host of accounting schedules and agricultural plans that dictated their work routine. One very important accounting schedule was known as the "economic year" (i.e. fiscal year) of the kolkhoz. The economic year began on 1 October and concluded on 30 September, and was used for determining the dates when government procurement contracts and MTS contracts for tractor services commenced and ended, when taxes and other state obligations were due, and when food rations and work-day compensation could be calculated and distributed to kolkhozniki. The economic year was also used when measuring the success of a kolkhoz and its chairman, and for filing kolkhoz production reports with state officials.

To ensure that kolkhoz chairmen completed the agricultural work of their kolkhozy on time, the Khortytsia and Molochansk REC and MTS circulated agricultural "calendar plans" for the entire raion. These plans provided detailed 
schedules of when kolkhozy and other agricultural enterprises in the raion were to begin and conclude specific agricultural tasks. The plans typically commenced on 1 January and were subdivided into three- or four-month instalments that were circulated to the kolkhozy a few months in advance of when they were to be implemented. Each instalment was typically several pages in length and included both a weekly and a three- or four-month timetable for the commencement and completion of specific agricultural tasks, such as spring ploughing, seeding, weeding, harvesting, and fall ploughing. In the summer of 1930, for instance, the Molochansk calendar plan stipulated that the harvest of 85,600 hectares of all kolkhoz fields in the raion would be completed according to the following deadlines: 8 days for mowing kolkhoz fields, 23-25 days for threshing, 13-15 days for harvesting sunflower seeds, and 15 days for harvesting corn. Calendar plans usually included "control figures" (targets) that kolkhozy were expected to follow or attain; for instance, many plans stated the exact number of tractors and horses that each kolkhoz was expected to use to complete its fieldwork according to the government-set timetable. Such plans were based on optimistic, if not utopian conditions and were unrealistic in terms of the number of days allotted for each specific task. In the opinion of some kolkhoz chairmen, the plans paid little regard to the practical realities of farming, nor did they take into account the amount of land, number of members, or type of equipment that each kolkhoz had at its disposal. ${ }^{62}$

Local officials also circulated detailed plans for specific kolkhoz tasks. These tasks included: seeding grain, root crops and sunflowers; delivering spring straw to government storage sites; harvesting crops according to a precise schedule; and delivering grain and meat procurements. Once again, the plans followed governmentset "control figures" that the kolkhozy were expected to reach in terms of their respective grain, meat and agricultural produce production. There were also detailed plans for increasing the amount of cultivated land in each kolkhoz by bringing into production areas that had previously been considered swampy, barren, or of low agricultural quality. Although most peasants immediately saw the folly of farming this land, kolkhoz chairmen were under enormous pressure to announce large annual increases in the amount of arable land in their areas. The Molochansk raĭon alone saw a 12.2 percent increase in collectivized cultivated land from 110,770 hectares in 1930 to 124,310 hectares in $1931 .{ }^{63}$ Sometimes the kolkhoz chairmen were consulted during the drafting of these plans to expand arable land in the raiony, but as was the case with so many government policies and programs, the plans were usually imposed from above. Every chairman was nevertheless expected to develop an agricultural plan or work plan for the kolkhoz that was synchronized with the existing REC's

The Carl Beck Papers in Russian and East European Studies http://carlbeckpapers.pitt.edu | DOI 10.5195/cbp.2015.199 | Number 2305 
calendar and specialized plans, accepted by the kolkhoz membership, and approved by the village soviet. ${ }^{64}$

There were a host of factors, including uncooperative weather, periodic crop failures, and less than cooperative kolkhozniki, that often made it impossible for a kolkhoz chairman to adhere to the schedules and plans. The decisions and actions of local authorities could also scuttle a chairman's plans and deadlines. Regional and raĭon state agencies, for instance, often amended the terms of kolkhoz procurement contracts unilaterally on short notice, resulting in significant increases in the amount of agricultural products that each kolkhoz had to deliver to the state, but without any extension of the delivery deadlines. One state agency that was notorious for breaking its contracts with the kolkhozy was the MTS. In 1931, each Molochansk kolkhoz was required to negotiate contracts with the local MTS for the provision of ploughing, sowing, and harvest services to the kolkhoz in exchange for agricultural products and fees. Sometimes the kolkhoz chairman attended the negotiations, but in other cases the kolkhoz membership elected a committee for this purpose. Whatever was agreed to between the kolkhoz and the MTS did not necessarily matter, however, as inadequate tractor fleets and high rates of mechanical breakdowns meant that the MTS often broke its promises. As a result, kolkhoz ploughing, sowing, and harvest work was frequently completed very poorly, late or not at all. ${ }^{65}$

With respect to the overall management of the kolkhoz as an agricultural enterprise, certain times of the year were busier for kolkhoz chairmen than others. The months of January and February, for example, were stressful for chairmen as they were still concluding outstanding matters from the previous economic year. The relentless, threatening directives of village soviet officials demanding that kolkhoz chairmen honor past procurement contracts created a headache for many chairmen. Officials often imposed November or December deadlines for fulfillment of these contracts, but because a high percentage of kolkhozy repeatedly failed to deliver their agricultural produce in a timely manner, officials had no choice but to extend the delivery deadlines into late January. To emphasize the seriousness of the situation, officials periodically sent procurement brigades to collect whatever grain was available and warned chairmen that they would be held criminally responsible for any shortfalls that persisted after the January deadline. On 24 January 1932, for instance, officials of the Ohrloff village soviet reminded the chairman of the Nadezhda artel (Ohrloff Molochansk) that his kolkhoz had only delivered 164.08 centners of grain (53 percent of its quota), and that he had twenty-four hours to deliver the outstanding 142 centners, failing which he and his administration would be arrested and put on trial. ${ }^{66}$ 
During January and February, kolkhoz chairmen were also busy making final preparations for the spring ploughing and sowing campaigns. These preparations included seed cleaning and repairing equipment. After the Khortytsia and Molochansk kolkhozy transferred the bulk of their best farm machinery to the MTS in 1930-31, it was the MTS director, not the kolkhoz chairman, who dictated when tractors and other agricultural machinery were available to perform important fieldwork. If MTS equipment was late or failed to show up, the chairmen resorted to using whatever horses, oxen, and agricultural equipment were available on their kolkhozy to do the work. Most kolkhoz calendar plans anticipated that the ploughing and sowing campaigns for the majority of crops would be completed by the third or fourth week of March, but a late spring thaw, a wet spring, or the late delivery of MTS equipment could delay the completion of spring seeding campaigns until April or early May. ${ }^{67}$

The pace of work for kolkhoz chairmen accelerated in May and June, as they were now preoccupied with supervising the harvest of crops, such as winter wheat and fall rye, that had been sown the previous fall. The chairmen also had to ensure that the first, and perhaps the second weeding of crops was completed, and that any mice or insect extermination campaigns were underway in the fields. ${ }^{68}$

Activity at the kolkhozy reached its peak during the months of July, August, September, and October. From late July to the end of August, the government sent out a barrage of propaganda and directives demanding that the kolkhozy honor their meat procurement contracts and deliver thousands of pounds of livestock and butchered meat before the end of the economic year. Most chairmen could not meet these arbitrary deadlines, so the government reluctantly extended the deadlines to the end of November. ${ }^{69}$

The summer and early fall were also devoted to bringing in the harvest, particularly the grain that had been sown in spring. In an effort to meet calendar plans for the harvest campaign, chairmen often ordered their kolkhozniki to work up to twenty hours a day until all the crops were taken off the fields and delivered to government and kolkhoz storage sites. If the harvest was late, chairmen did everything they could to keep their members working on the fields, even when the weather was uncooperative. Some implemented two twelve-hour work shifts per day, ensuring that there were always workers on the fields. The chairmen of the Liebenau and Rosenort kolkhozy in Molochansk ordered portable kitchens and sleep wagons to be set up on the fields so that kolkhozniki could eat and sleep near the crops until the harvest was finished. Additional night watchmen were assigned to patrol the fields to keep an eye on disgruntled members and to prevent the sabotage of farm equipment or the theft of grain. E. Braun, the Mennonite chairman of the

The Carl Beck Papers in Russian and East European Studies http://carlbeckpapers.pitt.edu | DOI 10.5195/cbp.2015.199 | Number 2305 
Dmitrov artel (Osterwick, Khortytsia), ordered the slaughter of additional hogs to ply members with much sought-after meat to keep them on the fields. If the weather was uncooperative or the MTS was unable to provide threshing services in a timely fashion, the harvest of cereal crops was postponed until November or December. If winter set in early, the harvest was put off until the following spring. ${ }^{70}$

In October, November and December, kolkhozy usually harvested sugar beets, potatoes and other root crops; delivered contractual procurements for these crops to government storage areas; and began the fall ploughing and sowing of winter wheat and fall rye. Because some kolkhozy were in the practice of sowing almost half of their annual wheat crop in the fall, the autumn ploughing and sowing campaigns were critical undertakings that were both labor-intensive and time-consuming. Once again, unpredictable contingencies could either delay these tasks until December or prevent their completion altogether.

Late autumn and early winter were stressful for kolkhoz chairmen for other reasons. Because the economic year for most Khortytsia and Molochansk kolkhozy concluded at the end of September, chairmen were under enormous pressure to complete year-end tasks as soon as possible, and certainly no later than December. These tasks included addressing any outstanding concerns that the REC and village soviets had concerning the harvest; completing the fall ploughing and sowing of winter crops; creating a plan to make up any shortfalls in procurement contracts; preparing annual reports on the kolkhoz's economic year and filing them with the REC and village soviet; and setting aside adequate grain and agricultural produce to meet government-prescribed kolkhoz insurance premiums, kolkhoz seed and reserve fund requirements, as well as requirements for livestock fodder reserves. ${ }^{71}$

Another very important task that the kolkhoz chairman had to complete in late fall was ensuring that his kolkhoz had delivered whatever was demanded by the "mobilization-of-the-means" campaigns. Touted in government newspapers as a voluntary means for peasants to support the state, the mobilization-of-the-means campaigns were actually monthly government directives issued to each kolkhoz ordering its members to deliver prescribed amounts of money, personal property, and agricultural produce to pay for a host of state-imposed taxes and obligations, which included: the agricultural tax, self tax, state tax, national insurance, state industrialization fund, credit fund, savings bank system fund, consumer cooperative fund, group cooperative fund, housing cooperative fund, state debt fund, shares-inthe-tractor-center fund, mobilization-of-the-means fund, local tax, organization-ofthe-land-workers' fund, rents, cartage, commune fund, and state obligations. The campaigns were onerous and effectively siphoned off large amounts of money, private 
property, and livestock that kolkhozniki had been permitted to keep for themselves. In late 1931, for example, Molochansk authorities ordered kolkhozniki and noncollectivized households in the răon to deliver 539,700 rubles in October, 319,700 rubles in November, and 176,900 rubles in December. By December, however, only 45.2 percent of this quarterly quota had been met. Before the end of the economic year, local authorities issued scathing directives to kolkhoz chairmen to ensure that their kolkhozy honored all of the voluntary payments expected from the monthly mobilization-of-the-means campaigns. ${ }^{72}$ Only after a kolkhoz chairman had ensured that all obligations to the mobilization-of-the-means campaigns were delivered, all procurement contracts honored, all government taxes paid, all other financial obligations paid, and all kolkhoz reserve funds filled could he finally permit the distribution of the remaining grain and produce to the kolkhoz membership. This important task usually occurred in late autumn, but was sometimes delayed until January or February.

The seasonal demands of managing a kolkhoz required the chairman to attend numerous meetings, the most important of which were those involving the REC, the village soviet, and village activist members. Kolkhoz chairmen were occasionally summoned to appear before the REC or MTS for serious matters such as persistent failure to meet government contracts and procurement quotas or contentious disputes between kolkhozy. In the spring of 1930, for instance, the Mennonite chairmen of the Nadija artel (Schöneberg, Khortytsia) and Pachar artel (Rosengart, Khortytsia) were summoned before the REC chairman to resolve an ongoing dispute between the two kolkhozy concerning ownership of a plot of land. More often the kolkhoz chairmen encountered REC, MTS, WPIC or party representatives at the meeting of the village soviet, where the chairman was expected to provide updates on the economic, agricultural, and cultural affairs of his kolkhoz, and answer any questions posed by the other members of the village soviet. The most stressful of these meetings usually occurred in the fall or early winter when kolkhoz chairmen had to answer for the performance of their kolkhozy during the past economic year. If a kolkhoz met or exceeded government expectations, then the chairman had little to fear. In fact, REC and village soviet officials often feted the most successful kolkhoz chairmen in the local newspapers, extolling them as shining examples for others to emulate, and publishing their names in an honor roll (Ehrentafel) of the best kolkhoz chairmen in the raion. ${ }^{73}$ REC and village soviet officials in Khortytsia, for instance, published lists in Stürmer that ranked each kolkhoz in the raĭon according to the amount of grain delivered to the state or the progress of the completion of the fall seeding requirements.

The Carl Beck Papers in Russian and East European Studies http://carlbeckpapers.pitt.edu | DOI 10.5195/cbp.2015.199 | Number 2305 
Conversely, chairmen of kolkhozy that failed to meet government targets for the past economic year often received a tongue-lashing in front of village activists and other chairmen in attendance at village soviet meetings. The chairmen also had to answer to government officials who demanded to know how their kolkhozy intended to make up the deficiencies. Officials also tried to shame poorly performing kolkhoz chairmen and kolkhozy by putting their names on a blacklist published in the local newspapers. To avoid public humiliation, underperforming kolkhoz chairmen sometimes tried to absent themselves from these meetings, sending someone else from the kolkhoz to bear the brunt of the criticism from government officials. ${ }^{74}$

Organizing and presiding over the many and varied meetings of the kolkhoz consumed much of a chairman's time. Arguably the most important of these were his meetings with the kolkhoz executive council, which was charged with administering the kolkhoz and included the kolkhoz chairman, secretary, bookkeeper/accountant, field manager, kolkhoz and village soviet activists, CVP members, and in some cases the kolkhoz brigadiers. In the early 1930s, the council at some of the larger Khortytsia and Molochansk kolkhozy, such as International kolkhoz in Khortytsia and Gigant commune in Molochansk, also included a political commissar or party organizer. By 1934, even the smaller Mennonite-populated kolkhozy, such as Triumph (NeuKronsweide, Khortytsia), Rekord (Nieder-Khortytsia/Blumengart, Khortytsia), and Kolos (Rosenthal, Khortytsia) had their own political commissars. The vast majority of these political commissars were Ukrainians and Russians, but there were also a few non-Mennonite Germans who served in this position. ${ }^{75}$

The executive council usually met once or twice a week, but during the busy ploughing, seeding, or harvesting campaigns it sometimes met as frequently as two or three times a day. Although the members of the council were supposed to regard fellow council members as colleagues and allies in the struggle to socialize the countryside, kolkhoz chairmen had to be careful about how they conducted themselves at these meetings, as it was commonplace for fellow members to report any purportedly anti-Soviet comments or actions to the village soviet, party cell, WPIC, or REC. ${ }^{76}$

The protocols of the executive council meetings indicate that the chairman and his administration discussed a wide range of topics. Some of the weightier issues included reviewing and implementing directives from local officials; screening candidates for service on kolkhoz committees; and negotiating ploughing, tractor, and threshing service contracts with the local MTS. The council also addressed minor matters, such as renting a bull from a neighboring kolkhozy for breeding purposes, organizing crews of children from the kolkhoz's work school to weed crops or hunt 
field mice, and planning the conversion of a former kulak or ekspertnik home into a community kitchen or bathhouse. ${ }^{77}$

Some of the most contentious issues discussed at these council meetings were how kolkhozniki should be paid for their work and what penalties should be imposed on kolkhozniki who refused to work on Sundays and religious holidays. In the late 1920s, most Khortytsia and Molochansk kolkhozy paid their members a wage or according to a "payment-per-eater" system, and did not require members to work on Sundays or religious holidays. This practice changed in late 1929 when the government introduced nepreryvka (the continuous work week), which required kolkhozniki to work most Sundays and religious holidays. ${ }^{78}$ In March 1931, the "labor-day" system of remuneration was implemented whereby kolkhozniki were compensated according to the number of "labor days" (trudodni or Arbeit Tage) that each accrued during the economic year. Each labor day was to be proportionate to the quantity and quality of work performed by all of the kolkhozniki. The remuneration for one labor day was determined at the end of the economic year after all state obligations and kolkhoz reserve funds had been met; whatever produce and money was left was divided by the total number of labor days earned by all of the kolkhozniki in the collective. Initially, it was the kolkhoz general assembly that developed formulas to determine what type of work and how much time devoted to it constituted a "labor day". Over time, however, the executive council assumed this task, in part because chairmen were concerned about how their labor days and those of their administration were formulated. ${ }^{79}$ In 1931, for instance, the executive council at the Rosenort artel in Molochansk determined that the chairman should be credited with having worked thirty days a month, regardless of how many days on the job the chairman actually spent. The council also decided to increase the value of the labor day of the chairman and his administration: one labor day for the chairman was now equivalent to a kolkhoznik who had worked three labor days planting pumpkins on three hectares of land, or two labor days weeding two hectares of carrots, or two night shifts as a watchman on the kolkhoz. Finally, the council began to impose harsh penalties on those who were absent from work on Sundays or religious holidays: six labor days were deducted for every Sunday or religious holiday that a kolkhoznik failed to report for work. This penalty proved particularly severe for Mennonite kolkhozniki who often refused to work on Sundays and religious holidays. ${ }^{80}$

Sometimes there were allegations that the way in which a chairman and his administration were calculating labor days for the rank-and-file members had more to do with ethnic bias than proper arithmetic. This was the case in Ohrloff(Molochansk),

The Carl Beck Papers in Russian and East European Studies http://carlbeckpapers.pitt.edu | DOI 10.5195/cbp.2015.199 | Number 2305 
where the majority of kolkhozniki were ethnic Germans, while the chairman and most of the executive council members were Ukrainian and Russian. In August 1933, the Russian chairman of the kolkhoz, Movchan, published a list of the most prized kolkhozniki; the list included the names of twelve Ukrainians and Russians, but only one Mennonite. The Mennonite members complained to local authorities that there were at least twenty-five ethnic German/Mennonite kolkhozniki who earned between two hundred and three hundred labor days, but who had been excluded from Movchan's list. The local authorities agreed with the Germans, removed Movchan from his position as chairman, and sent him to the People's Court to be tried for class hatred, perversion of the government's nationalities policies, and kulak activities. ${ }^{81}$

The kolkhoz chairman was also responsible for convening and chairing the meetings of the kolkhoz general assembly. Like the kolkhoz executive council, the assembly usually met once a week, but convened meetings as frequently as twice a day during busier periods of the agricultural year. In theory, the chairman was supposed to use the general assembly meetings to solicit opinions on issues affecting the kolkhoz and to reach a consensus on a course of action. In reality, however, kolkhoz chairmen had little confidence that the members would arrive at the correct decision on their own, and so chairmen sometimes employed subtle and not-so-subtle techniques to orchestrate a predictable outcome on important votes. For example, if a chairman feared strong female opposition to a particular proposal, he could schedule the meeting to discuss the proposal at a time that was inconvenient for female kolkhozniki, such as the late evening or early morning, when most women were likely to be preoccupied with their children or household responsibilities. ${ }^{82}$ When necessary, chairmen also resorted to more serious tactics, such as threats and bribery, to ensure that the membership rubber-stamped their proposals.

The minutes of the general assemblies reveal the diverse matters that were discussed. Some of the most common and also the most important proposed resolutions were those to ratify directives of the kolkhoz executive council and government agencies, discuss agricultural and livestock progress reports, confirm new candidates to fill vacancies on the kolkhoz executive and committees, vet peasant applications to join the kolkhoz, and determine household food rations and milk quotas. Most assembly meetings also addressed mundane but contentious issues, such as selecting which kolkhoz households would share a piglet, choosing prizes for an upcoming kolkhoz lottery, or determining whether children should be playing on village streets in the evening. At an assembly meeting of the Rosenort artel (Molochansk) in March of 1931, for instance, the seventy-two members (twentyfive women, forty-two men, and five executive members) in attendance discussed 
a variety of issues - important and mundane - including a proposal from the artel bakery committee to provide the bakery with half a pood of flour per person per month; a proposal to build a communal kitchen for all kolkhozniki; a proposal to accept the application of the Mennonite, Maria Dück, as a member of the artel; a proposal to expropriate the land of a non-collectivized household that bordered the artel; the confirmation of a decision to rent the artel stallion to the neighboring Tiege kolkhoz for eight rubles per service; a review of new milk procurement demands from local authorities; and the decision to allow the Mennonites Anna Martens, Giese Janzen, and Lena H. Epp to take medical courses at the nearby Ohrloff hospital. ${ }^{83}$

The chairman also used the assembly meetings to publicly chastise, embarrass, or even expel kolkhozniki for everything from minor misdemeanors to serious crimes such as kulak sabotage against the kolkhoz. In late 1929, for example, the chairman of the Fortschritt SOZ (Khortytsia) announced to his kolkhoz assembly that the following "worthless persons" (all of whom were Mennonite) had to be expelled immediately for a variety of reasons: Jakob J. Epp as a former owner of a mill; Abram Friesen as a vermin element; Kornei J. Dyck as a speculator; Abram J. Heinrichs as a disenfranchised landowner; and Kornei Zacharias as the son of a disenfranchised landowner. ${ }^{84}$ These public scoldings and punishments frequently occurred when representatives of the REC or village soviet appeared, often unannounced, at an assembly meeting and the chairman tried to impress his political masters with his authority over the membership.

Sometimes it was the local authorities who usurped control of the assembly meeting from the kolkhoz chairman, imposed their own agenda, and had the membership approve the expulsion of fellow kolkhozniki. This is what happened on 9 August 1930 when comrades Margenholz (Khortytsia MTS director), D. K. Loewen (a Mennonite agronomist working for the Khortytsia REC), and Merklinger (chairman of the Osterwick village soviet) appeared at the general meeting of the Hoffnung artel (Khronsthal, Khortytsia) without notice. Among other things, the triumvirate directed the Hoffnung members to the following resolutions: a new meat procurement plan to be delivered to officials later that month; the implementation of a plan to pay a five-year, 1,400-ruble loan within a four-year period by organizing contests with the nearby Bauer artel in Osterwick; a plan to liquidate the personal loans of members of the Khliborob association; the appointment of a committee to determine the number of excess horses at Hoffnung; and the confirmation of a proposal to implement recently drafted regulations for the operation of the artel. Before the meeting was over, Margenholz also convinced the membership to expel 
one Ukrainian household and four Mennonite households from the artel, and to accept one Ukrainian household and two Mennonite households as new members. ${ }^{85}$

Chairmen could also be the focal point of criticism at these assembly meetings. In fact, it was common for both kolkhozniki and visiting officials to use the assembly meeting as a public forum to challenge the decisions of the chairman and lambast him if he was performing his duties poorly. Kolkhoz chairmen were also subject to criticism from urban workers who were sent to the countryside to provide proletarian leadership in the kolkhozy during the spring fieldwork and summer harvest. In spring 1930, for instance, workers from the nearby Dniprostro1 mega-hydroelectric dam project were ordered to help local Khortytsia kolkhozy with the seeding campaign and cultural work including eradicating illiteracy, supporting the fight against religion, liquidating the kulaks as a class, and organizing tours of Dniprostrol for kolkhozniki. Many of the Dniprostroĭ workers knew little about large-scale farming, but whenever they appeared at the kolkhozy they usually took charge of the assembly meetings and barked out their slogans and orders for more proletarian discipline. The workers returned to Dniprostroĭ a few days or weeks later, leaving the chairmen to fix the problems that the workers left behind. ${ }^{86}$

The general assembly was not the only venue where the chairman addressed the concerns of the kolkhoz membership. The chairman was also expected to act as an arbitrator in resolving public and private disputes among kolkhozniki, which ranged from the shared use of kitchen facilities to spousal abuse. Those chairmen who did not have the confidence of their members were consulted less frequently, if at all, especially if members believed that the chairman could not be trusted to keep their personal matters private or might use the personal information against the member at a later date.

Presiding over the discipline and expulsion of kolkhozniki from the kolkhoz was another unpleasant task that fell to the chairman. The chairman and the executive council typically received complaints from activists, party members, party candidates, WPIC, brigadiers, and ordinary kolkhozniki about members who broke kolkhoz rules or committed other infractions. The chairman and the executive council each reviewed a complaint and came to a preliminary decision about whether the complaint was warranted; if it was, they determined what type of discipline was appropriate. Their recommendation was then forwarded to the general assembly for review and ratification. Minor infractions of kolkhoz rules, such as failing to show up for work on time, public drunkenness, or allowing children to attend church instead of school, usually resulted in the offender losing some accumulated labor days, having his or her milk, food rations or wages reduced, or being fined. The typical fine for a parent 
whose child attended church instead of school was five rubles per child per incident. More serious infractions of kolkhoz rules, such as theft or arson involving kolkhoz property, often resulted in the chairman and executive council recommending the immediate expulsion of the accused kolkhoznik. ${ }^{87}$ Serious matters were usually forwarded to the People's Court, which had a reputation for high conviction rates and harsh punishments, including incarceration, exile, and execution.

Motivating kolkhozniki to complete their assigned work tasks was a daily preoccupation of kolkhoz chairmen. This responsibility was especially onerous when the ploughing, sowing, and harvesting campaigns were underway, and the energy and enthusiasm of the kolkhozniki were flagging. In such circumstances, chairmen relied on a host of tactics to build morale. One technique was to organize socialist competitions between kolkhoz members as well as between neighboring kolkhozy and work brigades to see who could outwork the other and, in so doing, foster a sense of kolkhoz pride. Members of the K. Liebnecht kolkhoz (Schönhorst, Khortytsia) proudly reported in Stürmer that 155 members of the kolkhoz (including 55 school children and their teachers) participated in a one-day socialist competition on 10 June 1934 to destroy grain beetles in the kolkhoz fields. The kolkhozniki destroyed a total of 267,500 grains beetles, which according to the reporter, was tantamount to saving 5,350,000 ears of wheat (or 1.1 hectares of grain) from destruction. While praising the heroic efforts of these kolkhozniki, the article also chided the hundred or so members of the kolkhoz who did not participate in the campaign, and encouraged all kolkhozy in the district to follow the lead of K. Liebnecht in the destruction of crop pests. Kolkhoz chairmen sometimes promised those who worked the most hours during a ploughing, seeding or harvesting campaign that they would be honored as outstanding state Stürmer (strikers/attackers) in the local newspapers ${ }^{88}$ To motivate the entire kolkhoz to complete a particular work assignment on time, a chairman might promise his kolkhozniki a special buffet meal, a lottery for a calf or pig, or a day of rest on an upcoming Sunday or religious holiday.

Occasionally the local newspapers honored Mennonite chairmen when their kolkhozy completed a government procurement contracts or seeding programs on time. In March 1934, for example, the Khortytsia paper Stürmer published an honor roll that included Mennonite and non-Mennonite chairmen whose kolkhozy had completed their spring seeding by the March deadline. To ensure that the chairmen did not take all of the credit, however, Stürmer also published the names of each of the kolkhoz party organizers with equal prominence. ${ }^{89}$

One of the most challenging tasks that chairmen faced was implementing the government's anti-sectarian and anti-religion policies. An amendment to the 1924 
Soviet Constitution prohibited all religious propaganda and enabled local authorities to arrest any church leaders accused of participating in evangelistic activities; in essence, this amendment confined ministers to preaching only within their own congregations. The 1929 Decree on Religious Associations prohibited churches from supplying aid to their members or charities; holding special meetings for children, youth, or women; conducting general meetings for religious instruction, study, or recreational purposes; and opening libraries or storing any books except those necessary for conducting worship services. This law also banned religious instruction for children under eighteen unless this instruction was from their parents. It was also illegal for anyone to teach a Sunday school class, hold a prayer meeting, or lead a church youth choir. In August 1929, the government introduced nepreryvka, which banned Sundays and religious holidays (including Christmas and Easter) as special days of rest for workers and school children. There was also the 1929 Instructions of the People's Commissariat of the Interior, a law that required all religious associations to register with local officials by 1 March 1930 or be deemed closed. It also granted local authorities broad discretionary powers to grant or withhold the registration of local congregations, treat any unregistered religious service as illegal, and limit or reduce the number of religious associations in their jurisdictions. And as was noted above, the government's anti-sectarian policies in its secret decree of 30 January 1930 called upon officials to identify and treat sectarian communities as bases of support for kulaks, disenfranchised persons, and anti-Soviet elements..$^{90}$

Like all kolkhoz chairmen, Mennonite chairmen were expected to toe the government line on matters of religion, but some Mennonite chairmen were more zealous than others in enforcing government policies. All chairmen were expected to be secular role models and provide instruction to kolkhozniki in the folly of religious faith and practice. They were also expected to close churches and prayer houses in their villages; monitor permitted and prohibited religious activities in the kolkhoz; report and stop any efforts to convert kolkhoz youth to the Mennonite faith; and assist the local League of the Godless cells when they conducted their anti-religion propaganda campaigns, organized public debates with local religious leaders, and established anti-religion clubs on the kolkhozy. The chairmen imposed penalties on those kolkhozniki who attended religious services instead of their scheduled work routines, kept their children home from school on Sundays, permitted their children to attend church services, or decorated Christmas trees. ${ }^{91}$

Mennonite chairmen were not alone in meeting their anti-religion responsibilities. They had assistance from some or all of the following individuals or groups: members of the local cell of the League of the Godless, the party, Komsomol, CVP and WPIC; 
kolkhoz activists; school teachers; brigadiers; political commissars; members of the kolkhoz's cultural commission; and those who supervised the kolkhoz's Rote Ecke (Red Corner cultural center), Lesehalle, Bauernheim, or Kollektivistenheim (collective farmers' club).$^{92}$ Through the use of anti-religious plays, movies, lectures, and question-and-answer sessions, these individuals and groups attacked and ridiculed the religious beliefs and practices of Christian kolkhozniki.

These anti-religion and anti-sectarian efforts had the desired effect in some kolkhozy. At Burwalde kolkhoz (Khortytsia), it was reported that twenty-one people, most of whom were Mennonites, advised the chairman that they no longer wanted to have anything to do with the "stupid church" and requested that the local communist party cell organize a League of the Godless cell in their artel so as to liberate all kolkhoz members from the "opium den" of religion. Mennonite kolkhoz chairmen also had a hand in the dissolution of Mennonite congregations. At the Hoffnung kolkhoz (Kronsthal, Khortytsia), for example, several female kolkhoz members brought forward a proposal to Mennonite kolkhoz chairman Hamm requesting that one of the local churches be used as a daycare and kindergarten. Hamm brought the proposal to the kolkhoz general assembly for consideration; after the assembly ratified the proposal, he ordered the church's conversion into a kindergarten..$^{93}$

It was the responsibility of the kolkhoz chairman to ensure that anti-religious holidays were properly celebrated in the kolkhoz and that religious holidays were not celebrated at all. The chairman, his administration, and the kolkhoz cultural commission organized parades, activities, special speakers, as well as musical and theatrical performances for Soviet holidays, such as Anniversary of the Red Army (1 February), International Women's Day (8 March), May Day (1 May), Anniversary of the CVP (May), Day of Honor for Stalin (Stalin Apel Estafette in June), Red Harvest (early August), Day of Harvest and Collectivization (14 October), Day of the Proletarian Revolution (7-8 November), and the anti-Christmas campaign (late December). To prepare for such events, some chairmen ordered that the front yards of the kolkhoz residences be cleaned, fences be painted, and a buffet meal be prepared. Kolkhoz chairmen also arranged for socialist competitions to coincide with religious holidays in an effort to dissuade kolkhozniki from observing religious traditions and celebrations. ${ }^{94}$

Some chairmen also organized anti-religion workdays. This occurred at the Khliborob kolkhoz (Neuenburg, Khortytsia) in the spring of 1934, when the chairman permitted Mennonite kolkhoz brigadiers Pätkau, Günter and Wiebe, as well as a party agitator and other kolkhoz members to organize a debate on "anti-Easter work." At the debate, it was resolved that God could not help the Khliborob kolkhoz, that

The Carl Beck Papers in Russian and East European Studies http://carlbeckpapers.pitt.edu | DOI 10.5195/cbp.2015.199 | Number 2305 
kulaks and preachers opposed the development of socialism, that religion hindered the development of mankind, and that all kolkhoz households must work during the Easter holidays. To this end, the members of Khliborob challenged kolkhozniki at the neighboring Kolos kolkhoz to a socialist "anti-Easter" competition on Easter Sunday using the following rules: 100 percent attendance of kolkhoz members at work; 100 percent of the daily work norm must be fulfilled; socialist competitions between the brigades and their members must take place; the daily field newspaper must be published; and a cultural evening with movies, activities, amusements, and youth assembly events must be organized. ${ }^{95}$

A chairman criticized for not doing enough to eradicate religious belief in his kolkhoz could be publicly chastised for his lack of anti-religious zeal. In 1934, for example, the chairman and the executive council of the Neuendorf artel (Khortytsia) were attacked in an article in the newspaper Stürmer. The article complained that many women and children in Neuendorf were attending church rather than the Kollektivistenheim on their days of rest, and pinned the blame for this squarely on the administrators of the kolkhoz and the Kollektivistenheim who failed to arrange radio broadcasts for kolkhozniki, supply the kolkhoz library with interesting books, organize more worker circles and lectures, and distract the youth from attending church events..$^{96}$

Mennonite chairmen also presided over the discipline hearings and periodic mass expulsions of kolkhozniki from their kolkhozy. These expulsions were usually triggered by external events and political decisions rather than local factors. One such chistka ("cleansing" or "purge") occurred in late 1929, shortly after the Central Committee of the Communist Party and the Central Control Commission initiated a chistka of party members and candidates in the spring of 1929. ${ }^{97}$ Inspired by the chistka of local party organizations, the Khortytsia REC and village soviets unleashed a series of examination commissions to expose and expel kulaks, ekspertniki, lishentsy, speculators, and exploiters who had allegedly infiltrated local government bodies and kolkhozy in the raîon. These chistki were carried out with Bolshevik zeal in Mennonite communities, and served as punishment for Mennonite settlements whose members fled to Moscow in a last-ditch effort to emigrate. Forty-two Mennonite households, for instance, were expelled from the Nadezhda artel (Schöneberg, Khortytsia) in December 1929. In January 1930, local officials initiated another chistka in the Khortytsia kolkhozy, claiming that large numbers of kulaks, ekspertniki, and lishentsy had wormed their way into kolkhozy. This time the Nadezhda artel saw the expulsion of twelve households. Mass expulsions from Khortytsia and Molochansk kolkhozy also occurred in the wake of the government's 
"Sweep-the-Kulaks-out-of-the-Kolkhozy-with-an-Iron-Broom" campaign in spring 1931, and again in 1932-33, when widespread famine conditions and draconian government grain and meat procurement policies compelled Mennonite chairmen to orchestrate mass expulsions of kolkhozniki who were purportedly sabotaging kolkhozy. Expulsion from the kolkhoz was tantamount to a death sentence for many kolkhozniki and their children, who found it virtually impossible to find work, housing, or food..$^{98}$

Mennonite chairmen were not above exploiting their power and using members for personal advantage or pleasure. Some chairmen, for example, used kolkhoz property for personal benefit, ensured that they received extra food rations and alcohol, and promoted family members to the best positions. At the Rekord kolkhoz (Nieder-Khortytsia/Blumengart, Khortytsia), Mennonite chairman Pätkau allowed his relatives, who were not members of Rekord, to use Rekord horses for their personal use; in return for Pätkau's generosity, his relatives returned the horses to the kolkhoz badly mistreated and lame. Pätkau also ensured that his father was appointed director of the dairy ferm at Rekord, thus guaranteeing that Pätkau and his family received a large jug of milk every day, even though many deserving families did not. At other kolkhozy, the chairmen used their position to demand special attention from members. Kolkhozniki frequently offered the chairman bribes or invited him to drinking parties in their homes in an attempt to gain his favor. As was the case with chairman Ens and his alleged dalliance with Sarah Koop at the Torgler kolkhoz noted in the introduction, some Mennonite chairmen reportedly received sexual services from female kolkhozniki, usually in exchange for better work conditions, larger accommodations, or more food rations. It is not clear from the available records, however, how pervasive this practice was. ${ }^{99}$

\section{Personal Enemies and Public Embarrassments}

While chairmen wielded enormous authority in their kolkhozy, they had to be very careful how they used their power and how others perceived they exercised their authority. The REC and RPC maintained a network of informants both inside and outside the kolkhozy to monitor chairmen and to provide ongoing information on the activities, attitudes and failings of kolkhoz chairmen. The informants outside the kolkhozy included representatives of the REC, RPC, village soviet, CVP, and other government agencies who conducted unannounced spot checks at the kolkhozy. 
The 25,000ers and 20,000ers also gathered information on chairmen. Their surprise inspections caused no end of difficulty for the chairmen. In late 1931, for example, 25,000ers descended on Molochansk kolkhozy to root out kulaks and ekspertniki who had infiltrated the collectives, ensure that kolkhozy honored all procurement contracts, and identify chairmen who exhibited religious tendencies, reactionary attitudes, or German nationalist aspirations. ${ }^{100}$

Party members, party candidates, and Komsomol members also kept a close eye on kolkhoz chairmen. In Molochansk, for example, a host of party organizations supervised chairmen, including party committees (at Gigant commune, Molochansk MTS, and Waldheim MTS), village territorial party groups (at Waldheim, Lichtenau, Prischib, Gosplenzhonovka, Steinbach, and Reichenfeld village soviets), kolkhoz party groups (at Grishino), kolkhoz party candidate groups (at Hierschau, Leninfeld, Muntau, Efimovka, Petrovka and Ohrloff), kolkhoz party Komsomol groups (at Khliborob, Friedrichsfeld, Heidelberg, Trudoliubimovka, Neu Nassau, and Mariaheim) and sovkhoz party groups (at Skalistiı̆, Ul'yanovka, K. Liebnecht, and K. Liebnecht No. 3). ${ }^{101}$ Kolkhozniki who were party members or candidate members sometimes acted as informants, providing local party cells with first-hand information concerning the conduct of their chairman, as did political commissars responsible for the political and cultural education of kolkhozniki. A negative report from a commissar sometimes resulted in the chairman's summary dismissal followed by a hearing at the People's Court. Kolkhoz chairmen also had to be mindful of colleagues on the kolkhoz executive council and audit commission because local authorities often recruited kolkhoz accountants, secretaries, field managers, brigadiers, and audit committee members to provide regular reports on the chairman's activities, conversations, and attitudes. ${ }^{102}$

WPIC members also monitored the activities and decisions of kolkhoz chairmen. Ensconced in almost every kolkhoz in Molochansk and Khortytsia, WPIC members had the mandate to identify and eliminate inefficiency and corruption at every level of the kolkhoz. They served as the government's auditors of kolkhozy, and their weekly and monthly reports to raǐon WPIC authorities and party organizations frequently resulted in the discipline or even dismissal of chairmen. In April 1932, for example, three Mennonite WPIC members (Schmidt, Görzen, and Penner) prepared a litany of complaints against the Mennonite chairman Friesen of the Novo Ukraïna kolkhoz (Grossweide, Molochansk), including allegations that he came from a family of large landowners and failed to strengthen his kolkhoz. They went on to accuse him of failing to defend socialist property and the USSR, advocating for kulak households, threatening the poor, and neglecting to properly account for 800 
rubles in his bank account. The Mennonite WPIC members concluded that Friesen was a distorted class enemy who endangered Novo Ukraïna. On the basis of this report, Friesen was replaced by a more class-conscious member of the kolkhoz. ${ }^{103}$

Kolkhoz chairmen also had to be wary of kolkhoz activists. Every kolkhoz in Khortytsia and Molochansk had its own cell of activists that typically included members of the CVP, WPIC, Komsomol, and occasionally members of the RPC. The activists prided themselves on being the most zealous and elite supporters of the regime and its policies in the kolkhoz, and usually met with the kolkhoz chairman on a weekly, and sometimes daily, basis to discuss kolkhoz matters. The activists routinely challenged the chairman's authority and decisions at these sessions, and felt duty bound to expose the chairman's ineptitude and disloyalty to local authorities if they believed he was not following the party line.

Although the majority of kolkhozniki were not kolkhoz activists, they too posed a possible threat to kolkhoz chairmen. While most kolkhozniki were deferential to their chairman in public, privately many viewed him as an agent of the state and the regime's de facto manager of peasant land, equipment and livestock. Kolkhozniki often resented the chairman's authority over their property and lives, and questioned his agricultural and managerial skills. Kolkhozniki were also jealous of the perquisites that the chairman received, such as higher wages, larger food rations, and better accommodation. There was a common perception among kolkhozniki that the chairman manipulated the labor-day system of remuneration to ensure that he received more labor-day credits than anyone else, regardless of how well the kolkhoz performed or how hard the chairman actually worked. ${ }^{104}$ Often hated and despised, kolkhoz chairmen soon discovered that the loyalty of their kolkhozniki was tenuous and wavering.

A disgruntled kolkhoznik sometimes vented his frustration by criticizing the chairman at kolkhoz meetings, but individual confrontations rarely proved successful; on the contrary, they were usually seen as acts of insubordination or counterrevolutionary behavior and resulted in the discipline or expulsion of the kolkhoznik. There were occasions when several kolkhozniki collectively challenged the authority of their chairman at a kolkhoz meeting in order to embarrass the chairman, force him to resign, or recall him. But this tactic backfired if the REC did not approve the chairman's resignation or enforced its directive prohibiting the recall of a kolkhoz chairman within one year of the chairman's appointment. ${ }^{105}$

Kolkhoz chairmen also had to be careful in their dealings with kolkhozniki who had close relationships with local officials, as these relationships could be used to intimidate the kolkhoz chairmen. One such kolkhoznik was Helene Hübert, a

The Carl Beck Papers in Russian and East European Studies http://carlbeckpapers.pitt.edu | DOI 10.5195/cbp.2015.199 | Number 2305 
Mennonite member at the Dmitrov kolkhoz near Osterwick, Khortytsia. Although Hübert had a reputation for being lazy and a bad influence on fellow kolkhozniki, she was not expelled from the kolkhoz because she had a close relationship with comrade Roschkow, the chairman of the Osterwick village soviet, and she used this to her advantage. For example, after not showing up for work for two months, Hübert approached the kolkhoz chairman, E. Braun, and demanded a large amount of straw to which she was not entitled. Apparently aware of Hübert's relations with Roschkow, Braun gave Hübert the straw "without a second thought," even though Braun knew that this would be to the detriment of hardworking kolkhozniki who were more deserving of it. Hübert, however, was not happy with what Braun had given her and went over his head by complaining to Roschkow. Roschkow subsequently met with Braun and the other members of the kolkhoz administration and ordered them to give Hübert whatever straw she wanted. As this report illustrates, kolkhozniki with friends in high places sometimes used their influence to manipulate the kolkhoz chairman. ${ }^{106}$

Poison-pen letters and anonymous reports published in local newspapers also proved effective in embarrassing chairmen, goading them to improve their performance, or destroying their reputations and careers. Such letters and reports often raised concerns about the alleged class-alien background of the chairman or his spouse, his connections with counter-revolutionary and foreign elements, or his mismanagement of the kolkhozy. This was the experience of the Mennonite chairman Penner of the Rote Fahne kolkhoz in Rosenthal (Khortytsia), who was chided in Stürmer for sleeping on the job and mismanaging the wheat harvest; the article called on Penner to wake up and pay more attention to the harvest campaign. Poison-pen letters and reports often detailed the chairmen's mistreatment of kolkhozniki. During the 1934 harvest, a member of the Torgler artel (Khortytsia) published a complaint in Stürmer alleging that D. J. Epp, the Mennonite chairman of the artel, was feeding his kolkhozniki a watery, inedible porridge made with foul-smelling oil. Epp was also blamed for the disappearance of a butchered pig that was supposed to feed the artel members. Stürmer published a similar complaint drafted by members of the first brigade at the Thälmann artel (Neudorf, Khortytsia). They alleged that their source of drinking water was a trough where animals drank and children bathed; they demanded that the chairman and his administration provide them with clean water. ${ }^{107}$

Local newspapers sometimes praised a chairman as a hero one day only to vilify him as an enemy of the people the next. Such was the experience of the Mennonite chairman Unger of the Faktor artel in Schöneberg (Khortytsia). On 28 March 1934, Unger's name was listed in Stürmer's honor roll as a socialist hero, but a few days 
later Stürmer published a letter written by members of the second brigade at Faktor in which they accused Unger of "twisting his head to every wagging tail of kulaks." They also complained that Unger was frequently away from work due to illness and called for him to step down as chairman. ${ }^{108}$

Kolkhoz chairmen were also lampooned in the local press for their corruption, laziness, alcoholism, and marital infidelities. A single published letter did not always result in the immediate dismissal or resignation of a chairman, thus forcing kolkhozniki to continue submitting maligning articles to the local press until the chairman was ousted. In the summer of 1934, for example, an unflattering article appeared in Stürmer accusing the Mennonite kolkhoz chairman Pätkau of corruption. Subsequently other articles appeared in Stürmer about Pätkau's alleged misdeeds, including one accusing Pätkau of using the horses and equipment of the Rekord kolkhoz (Nieder-Khortytsia/Blumengart, Khortytsia) as his own property, and arranging to have three kolkhoz piglets fattened on kolkhoz milk and grain for the benefit of his family. Pätkau's actions, the article alleged, forced more deserving kolkhozniki to use their meagre savings to purchase piglets at inflated prices at the local market. In the opinion of the author of the Stürmer article, Pätkau was a "kulak agent" at the highest level of the kolkhoz and must therefore be investigated. When this article did not result in Pätkau's removal, another disparaging article about Pätkau appeared less than two months later in which the Mennonite kolkhoznik, Giesbrecht, derided Pätkau as lazy and incapable of performing his duties. Giesbrecht complained that due to Pätkau's incompetence, the kolkhoz fields had not been ploughed for the fall sowing, not one kernel of millet had been delivered to the state storage site, silage production issues had been ignored, and the sunflower harvest had fallen behind. ${ }^{109}$

Some Mennonite chairmen tried to counter negative press by submitting their own reports to local newspapers, highlighting the contributions that they made to the kolkhoz. The newspaper editor, in consultation with local officials, determined whether such self-serving articles would be published. In some cases, the editor allowed the chairman's article to appear in the newspaper on its own; in other cases, the chairman's article was only published if there was an article from another source that challenged the chairman's version of facts. If the editor continued to allow more negative articles about a chairman to appear in the newspaper, then there was a good possibility that the chairman would soon be punished or dismissed. ${ }^{110}$ 


\section{Ethnic Challenges Encountered by Mennonite Kolkhoz Chairmen}

All kolkhoz chairmen in Ukraine faced enormous challenges in the early 1930s, regardless of their ethnicity. As members of the ethnic and religious minority, however, Mennonite kolkhoz chairmen faced certain unique challenges that many of their Ukrainian and Russian counterparts did not encounter. These additional challenges arguably arose from the discriminatory practices and policies of local officials, who often treated the Mennonite communities more harshly than other ethnic groups. The anti-Mennonite bias of local authorities was rooted in a variety of factors, including the sectarian identity of the Mennonite communities, their pre-revolutionary wealth, their identification as members of byvshie and kulak classes, their support of the German Army and the White Army during the civil war, their organization of Selbtschutz units during the civil war, their demands for special economic privileges through the VBHH, their emigration efforts during the 1920s, and their identification as "ethnic Germans." Khortytsia and Molochansk government records, which document the observations of local officials and describe Mennonite kolkhozy as "kulak nests" and "infested with kulaks and fascists," reflect this anti-Mennonite bias. The records also document the charges of some officials that Mennonite kolkhoz chairmen were passively permitting or actively assisting kulaks, ekspertniki, White Guardists, counterrevolutionaries and fascists to obtain memberships in their kolkhozy in order to protect them from dekulakization. In the minds of some Khortytsia and Molochansk authorities, kulak elements thrived in Mennonite and German communities, which posed the strongest opposition to the regime and its collectivization policies. Authorities therefore felt justified in implementing more aggressive administrative policies and measures in the Mennonite kolkhozy in order to purge them of their counterrevolutionary elements and bring the kolkhozy into line. ${ }^{111}$

The question that arises is whether the anti-sectarian, anti-German, and antiMennonite attitudes of local officials made the job of Mennonite kolkhoz chairman more difficult than that of non-Mennonite chairmen, and if so, then how? It is not easy to locate direct evidence that either proves or disproves that Mennonite chairmen were subject to discriminatory practices and additional challenges that their Ukrainian or Russian counterparts did not have to face; much of the evidence on this topic is circumstantial, and there are a variety of other economic, social, and political factors that may help to explain why some Mennonite chairmen were treated differently than non-Mennonite chairmen. But there is evidence to suggest that local officials 
supervised Mennonite chairmen and their kolkhozy more closely than Ukrainian chairmen and kolkhozy. In 1930 and 1931, for example, authorities from the Khortytsia REC and the village soviets attended the executive council and kolkhoz assembly meetings of Mennonite kolkhozy more often than they did at Ukrainian kolkhozy; at some Mennonite kolkhozy, such as Hoffnung (Dolinsk, Khortytsia), authorities attended more than twice as often as they did at neighboring Ukrainian kolkhozy. When these authorities visited Mennonite kolkhozy, they almost always chaired whatever meetings were scheduled, and frequently directed the chairman, executive council, and assembly to amend or cancel their past decisions. These officials believed that it was necessary to keep the Mennonite chairmen and their kolkhozy on a tight leash, which undoubtedly made the job of being a Mennonite kolkhoz chairman more difficult. ${ }^{12}$

Anti-Mennonite bias also appears to have been a factor in the election, appointment, and promotion of Mennonite chairmen. In the eyes of local officials, Mennonite kolkhoz chairmen were only suitable to manage kolkhozy that were largely populated by Mennonites and Germans: as a result, Mennonites were not permitted to manage Ukrainian or Russian kolkhozy. Conversely, non-Mennonite chairmen were routinely appointed to manage kolkhozy dominated by Mennonites. By 1931-32, for instance, a number of non-Mennonite chairmen were supervising Mennonite kolkhozy in the Molochansk raĭon: J. Hoppe at the Tiege kolkhoz in 193132; Peter Eirich at the Rosenort artel in early 1931; Gori at the Blumenort kolkhoz in 1932; and Anton Lavrik at Nadezhda artel (Ohrloff) in early 1932. In this regard, ethnic and sectarian identity appears to have limited the work and advancement opportunities for Mennonite chairmen. ${ }^{113}$

Anti-Mennonite discrimination also played an important role in the campaigns to rid Khortytsia and Molochansk kolkhozy of alleged kulak infiltrators. When local authorities in Khortytsia initiated a campaign to expel kulaks, bourgeois, ekspertniki, and lishentsy from local kolkhozy in January and February 1930, for example, they announced that kulaks had infiltrated Mennonite/German kolkhozy; consequently, they focused most of their chistka efforts on Mennonite kolkhozy. The results were predictable: Mennonite kolkhozy were found to be harboring far more kulaks, ekspertniki, and lishentsy than were Ukrainian kolkhozy. The majority of Mennonite-populated kolkhozy expelled five to ten families at a time during this campaign; some Mennonite kolkhozy, such as Nadia SOZ (Schöneberg, Khortytsia), were ordered to expel more than ten families. Ukrainian kolkhozy in Khortytsia were also affected by this dekulakization campaign, but to a much lesser extent. When the campaign was over, most Mennonite kolkhozy had witnessed the dekulakization

The Carl Beck Papers in Russian and East European Studies http://carlbeckpapers.pitt.edu | DOI 10.5195/cbp.2015.199 | Number 2305 
of 5 percent or more of their members, while most Ukrainian kolkhozy saw the expulsion of less than 1 percent of their members. ${ }^{114}$

The dekulakization campaigns in Mennonite kolkhozy in 1930 and 1931 created a number of challenges for Mennonite chairmen. The expulsion of large numbers of Mennonite kolkhozniki meant that Mennonite chairmen had to deal with wild fluctuations in their memberships, something that Ukrainian and Russian chairmen in the raĩon did not experience to the same extent. This decline in manpower made it difficult for Mennonite chairmen to meet their work plan commitments; perhaps more importantly, the decline resulted in the loss of important agricultural skills and experience that the Mennonite-populated kolkhozy needed to succeed. At the same time, the high dekulakization rates only confirmed the suspicions of local officials that Mennonite kolkhozy were more likely than kolkhozy dominated by any other ethnic group to be infiltrated by kulaks, which led them to conclude that Mennonite kolkhozy required even more administrative measures and supervision in the future. Predictably, this put additional pressure on Mennonite kolkhoz chairmen to prove to authorities that their kolkhozy were "kulak-free" and that their kolkhozniki were loyal to the regime. In an effort to alleviate officials' concerns, Mennonite chairmen helped organize and supervise periodic reviews of their membership, and routinely submitted their membership lists to the village soviets and REC for scrutiny. Mennonite chairmen also tried to motivate their kolkhozniki to exceed the expectations placed on them by authorities and whenever possible to outperform Ukrainian kolkhozy, especially in socialist competitions and in the delivery of crop procurement quotas. Mennonite chairmen had good reason to do whatever was necessary to prove to local authorities that their kolkhozy were free of any kulak taint.

Another challenge encountered by Mennonite chairmen in Khortytsia and Molochansk was that government officials often used ethnic considerations to decrease the landholdings of Mennonite kolkhozy. In early 1930, for example, Khortytsia officials alleged that there was an imbalance in the landholdings of Mennonite/German kolkhozy vis-à-vis Ukrainian kolkhozy. More specifically, there were more Mennonite kolkhozy and they were larger in size. In reality, Mennonite kolkhozy ranged from as small as the Kolos artel (534 hectares farmed by thirty-four households [15.71 hectares per household]) in Rosenthal to as large as the Bauer artel (2,800 hectares farmed by 130 households [21.54 hectares per household]) in Osterwick. Ukrainian kolkhozy, by comparison, ranged from as small as the Chervonii Boretz SOZ (27 hectares farmed by three families [nine hectares per household]) in Krasnopol to as large as the International commune (1,149 hectares farmed by 119 households [9.66 hectares per household]) in Khortytsia. Overall, 
Mennonite kolkhozy controlled more than 19,000 hectares, while Ukrainian kolkhozy managed less than 4000 hectares. To rectify this imbalance, the Khortytsia Raĭzemotel directed Mennonite chairmen to transfer tracts of kolkhoz land to "impoverished Ukrainian kolkhozy in the raion to facilitate better relations between the two national groups." 115 The REC also transferred land from a number of Mennonite villages (e.g. Kanzerovka) into Ukrainian-populated kolkhozy and merged a number of smaller kolkhozy into larger operations. In many respects, these measures aimed to redistribute valuable tracts of Mennonite land into Ukrainian hands, and had little to with sound agricultural, economic or ethnic considerations, or the long-term viability of kolkhozy. In the late summer of 1930, Khortytsia officials called upon Mennonite village soviets to donate hundreds of hectares of land for the purpose of establishing zborni (temporary settlements for kulak households) in the raion. To meet these obligations, some village soviets appropriated land for the zborni from Mennonite kolkhozy. The chairmen of the affected Mennonite kolkhozy were powerless to stop the officials from transferring the land in question. ${ }^{116}$

One question that arises is to what extent, if any, did anti-sectarian, anti-German or anti-Mennonite bias influence the decisions of local authorities with respect to other important matters that affected Mennonite chairmen and their kolkhozy? More specifically, did this bias affect decisions concerning grain and meat procurement requirements, the awarding of fermy to Mennonite kolkhozy, quotas assigned for the mobilization-of-the-means campaigns, tax assessments on Mennonite kolkhozy and their members, and the provision of MTS tractor and agricultural equipment services? Some government records do single out Mennonites and Germans for special discriminatory or administrative measures; as was noted above, officials in Khortytsia targeted Mennonite/German communities with extra grain procurements in June 1930 after large numbers of Mennonites refused to re-enter the kolkhozy following the publication of Stalin's "Dizzy with Success." But in most cases, it is impossible to categorically state that anti-sectarian, anti-German or anti-Mennonite attitudes of local officials consistently played a role in the drafting and implementing of policies and decisions that affected Mennonite chairmen and their kolkhozy. Understandably, the minutes of meetings of the kolkhoz executive council and assembly rarely refer to the discriminatory practices that Mennonite chairmen and their kolkhozniki experienced at the hands local officials. Knowing that these minutes would eventually find their way back to authorities and could result in further retributions, most Mennonite kolkhozniki and chairmen were shrewd enough not to blatantly complain about discrimination and bias at kolkhoz meetings. 


\section{The Famines of 1932-33 and the Marginalization of Mennonite Kolkhoz Chairmen}

The challenges of managing a kolkhoz intensified in late 1931 and early 1932 when famine conditions began to emerge in Khortytsia and Molochansk. There was no single cause of the famine conditions; rather, a multiplicity of factors converged to result in a significant deterioration of day-to-day life on kolkhozy. Widespread starvation soon gripped various regions of the country, including many urban centers, and, by 1932-33, at least two separate famines had emerged. The first famine was the Kazakhstan famine that developed in late 1931 and continued until 1933. The second was the disastrous famine in the main grain-producing areas of the country, including Ukraine, the North Caucasus, and Volga regions, which began in the spring of 1932 and intensified until the harvest of 1933. These famines proved catastrophic. In April 1932, for example, the death rate in the Ukrainian countryside rose above its normal level and remained high until August; the death rate briefly returned to normal after the 1932 harvest but quickly rose to above normal in November. By June 1933, the death rate in some areas was thirteen times higher than normal. While it is impossible to calculate the exact number of famine deaths in 1932-33, most scholars estimate that between 4.6 and 8.5 million people died as a result of the famines, with 3 to 3.5 million of those deaths occurring in Ukraine. ${ }^{117}$

The Soviet leadership was aware of the desperate circumstances in the countryside and modified some of its policies to alleviate the suffering of peasants. In May 1932, for example, the government reduced its grain collection plan for the country from 23.5 million tons to 19 million; in the end, however, only 18.5 million tons were collected. The 1932 grain collection target for Ukraine was later reduced from 5.83 million tons to 3.77 million; only 3.53 million tons were actually collected. The Politburo also issued thirty-five secret directives authorizing the release of modest amounts of food (194,000 tons) to Ukraine. All of these measures, however, failed to stem the increasing death toll. ${ }^{118}$

Problems with Ukraine's grain collection program were already evident in late 1931, when it was reported that the republic had delivered only 78.7 percent of its 1931 grain procurement plan. Disappointed with these results, the Politburo directed Ukraine to fulfill its grain procurement plan by February 1932, a deadline that was not only impossible to meet, but which also accelerated the development of famine conditions in the republic. In January 1932, the Ukrainian leadership reacted to the growing crisis by disbanding the administrations of 250 kolkhozy 
and charging 345 kolkhoz administrators with the offense of hampering the work of grain procurements. In July 1932, the Ukrainian leadership tried to address the shortcomings in the grain collection program at the third conference of the Communist Party of Ukraine. Present at the conference were Stalin's lieutenants L.M. Kaganovich and V. M. Molotov, who heard reports that Ukraine's spring sowing campaign had failed. They were also informed of widespread rumors circulating in the countryside that Ukraine had been targeted with unfair levels of taxation, that Moscow's grain procurement targets for Ukraine were unrealistic, and that Ukrainian peasants could not meet state quotas. In disclosing these issues to Kaganovich and Molotov, the Ukrainian leadership hoped to explain why the situation in Ukraine had become so dire. At the same time, the Ukrainian leaders blamed kulaks and Ukrainian nationalist elements, including Petlyurists, rightist elements, and Ukrainian chauvinists, who had allegedly infiltrated the party and government and spread these rumors. The Ukrainian leadership promised that retaliatory measures would be taken against these Ukrainian nationalist elements. ${ }^{119}$

Whether or not Kaganovich and Molotov were convinced that the Ukrainian leadership could solve the desperate conditions in the Ukrainian countryside is unclear, but they were undoubtedly left with the impression that Ukrainian nationalist elements had played an important role in causing the agricultural catastrophe now unfolding in the republic. Other members in the Soviet leadership shared this impression. On 5 August 1932, the OGPU issued a directive ordering its local agencies to put a stop to anti-Soviet groups and activities in the countryside, and more specifically to liquidate eight counter-revolutionary nationalist groups in Ukraine. Stalin also expressed serious concerns about the rise of dangerous nationalist elements in Ukraine. In an 11 August 1932 letter to Kaganovich, Stalin expressed his dissatisfaction with the situation in Ukraine and questioned the loyalty of the entire Ukrainian party leadership, which he said was dominated by Petlyurists and agents of the Polish leader Piłsudski. To prevent Ukraine from being lost to nationalist elements, Stalin demanded that immediate steps be taken to turn Ukraine into a "fortress of the USSR" and a "model republic" in the shortest possible time. ${ }^{120}$ Stalin was not specific as to how this was to be accomplished, but it was clear that all Ukrainian nationalist elements and Polish agents had to be eliminated.

For Mennonites in Khortytsia and Molochansk, it was not Ukrainian nationalists or Polish agents that posed the greatest threat to their lives; rather, it was the government's grain, meat and produce collection campaigns. In fall 1931, REC and RPC officials in both raîny not only increased the amount of agricultural produce that each kolkhoz was contracted to deliver, but also put enormous pressure on kolkhoz 
chairmen to exceed the procurement contracts. This fostered a competition between kolkhozy to see which one could deliver the highest procurement percentages. In Molochansk, for instance, the Mennonite kolkhoz of Tiege (Molochansk) was contracted to supply 115 centners of grain, but actually delivered over 210 centners - 183 percent of its quota. Sadly, this practice of overfilling quotas siphoned off much of the grain that the kolkhozy required for future sowings, animal fodder, and food rations. ${ }^{121}$

The government demand for more grain intensified in 1932, when regional and raĭon officials dramatically increased the grain, produce, and meat quotas for Khortytsia and Molochansk. The REC and RPC officials also insisted that kolkhozy deliver 80 to 85 percent of all their agricultural production to the state; kolkhozy were to use the remaining 15 to 20 percent to cover their future sowings, grain reserve funds, mobilization-of-the-means obligations, taxes, animal fodder, and food rations. These new expectations were difficult and sometimes impossible to fulfill. In Molochansk, for example, the government set the raĭon grain procurement plan at 240,928 tons for 1932 and 278,008 tons for 1933. Molochansk kolkhozy and sovkhozy were only able to deliver 132,908 tons (55.2 percent) in 1932; they delivered 278,008 tons (100 percent) in 1933, but at great sacrifice. ${ }^{122}$ Some kolkhozy found it easier to meet their portion of the quota than others, with the result that the death rates at Molochansk and Khortytsia kolkhozy varied significantly from one village to another.

To ensure that kolkhozy across the country fulfilled their procurement contracts, the regime issued a series of draconian laws and directives in late 1932. One of these legal measures was the "Seven-Eight" Decree implemented on 7 August 1932. It declared that all socialist property was fundamental for Soviet social order; all kolkhoz and cooperative property (including harvest in the fields, livestock, stores, and shops) had equal status with state property; and theft of kolkhoz and cooperative property (including petty theft of grain gleanings) was punishable by imprisonment or execution. To ensure that the "Seven-Eight" Decree was implemented in Ukraine, Molotov sent a telegram to oblast party committees on 5 November 1932 ordering them to take decisive action to enforce the decree and to undertake merciless punishment against criminal elements in the kolkhoz leadership. ${ }^{123}$

On 22 October 1932, the Politburo issued a directive creating an extraordinary commission headed by Molotov to deal with the disorganized grain collection program in Ukraine. In short order Molotov sharply criticized the Ukrainian leadership for its mishandling of the grain procurement plan. In early November, he organized grain commissions that began implementing measures to extract additional 
grain from the Ukrainian countryside. Molotov ramped up his attack against the rural population on 18 November 1932 when he issued the "Molotov Decree" extending the forcible grain requisitions in Ukraine to January 1933. The grain commissions now had the authority to confiscate not only grain, but also meat and produce from those who failed to meet their grain quotas. ${ }^{124}$

On 14 December 1932, the regime intensified its pressure on Ukraine by issuing a resolution to address problems associated with grain collections in Ukraine, the Northern Caucasus, and the Western Oblast. Among other things, the resolution directed the Ukrainian Sovnarkom to complete its procurement plans for grain and sunflower seeds by late January 1933, and to undertake the arrest and imprisonment of counter-revolutionary elements - including kulaks and Petlyurists - in the party, government institutions, and kolkhozy. The resolution also accused the Ukrainian leadership of improperly implementing its Ukrainianization policies, which allegedly contributed to the creation of new centers of bourgeois nationalists. According to the resolution, the only remedy for such ineptitude was a purge of nationalist elements among soviet and party cadres. ${ }^{125}$

On 27 December 1932, the regime passed its notorious passport law. It required all Soviet citizens who were more than sixteen years of age and living permanently in towns with more than ten thousand people, workers' settlements or state farms to obtain a government-issued passport and residence permit. Kulaks, ekspertniki, lishentsy, or those with criminal records were ineligible to receive a passport or registration permit. Anyone living in these areas without a passport was denied employment, and subject to fines, expulsion, imprisonment, or exile if caught by the OGPU. Kolkhozniki were not automatically eligible to receive a passport; a kolkhoznik could only obtain a passport if he or she obtained official written permission to leave the kolkhoz to obtain work in an area requiring a passport. ${ }^{126}$

The passport system served a number of important purposes for the regime. First, the system became an important tool for social control. More specifically, it enabled the government to purge the urban population of class aliens; to register the urban population; and to prevent kulaks, ekspertniki, lishentsy, and peasants in the countryside from leaving their villages and moving to areas where work and food were more readily available. Second, the system became a useful policing tool for identifying criminal, social, and national groups - kulaks, religious populations, Germans and Mennonites - effectively binding these groups to particular areas and making it impossible for them to migrate to other regions of the country without government permission. Finally, the passport system proved to be a useful tool for industrial enterprise directors and local officials to determine which individuals

The Carl Beck Papers in Russian and East European Studies http://carlbeckpapers.pitt.edu | DOI 10.5195/cbp.2015.199 | Number 2305 
(workers, government workers, or party members) living in urban and industrial areas where food supplies were scarce would receive food rations. ${ }^{127}$

In late 1932 and early 1933, the leadership in Ukraine implemented a series of policies and measures that made life intolerable for kolkhoz chairmen in Ukraine. On 18 November 1932, the Ukrainian Politburo ordered communists from industrial areas to form brigades of rural members for the purpose of locating grain in the countryside; each brigade was to have three to four members and at least two to four brigades were to be sent to each raǐn. The Politburo also stipulated that any kolkhoz that did not fulfill its grain quota was to be blacklisted. Kolkhozy that permitted the theft of grain and maliciously wrecked the grain procurement plan were required to pay a "fine in kind" consisting of fifteen-month quotas of meat deliveries to be provided in the form of cattle belonging to the kolkhoz and individual kolkhozniki. By early 1933, most kolkhozy in Ukraine were ordered to pay this "fine in kind". ${ }^{28}$

On 20 November 1932, the Ukrainian Sovnarkom ordered all kolkhozy to meet the 1 January 1933 deadline to deliver procurement quotas, with the threat that chairmen would be personally liable for any deficiencies in the procurement and any squandering of kolkhoz property. The Sovnarkom also directed local procurators to be especially vigorous in their prosecution of kolkhoz chairmen at the People's Court. ${ }^{29}$ In early December, the Ukrainian Sovnarkom banned the trade of potatoes, meat, animals, and other goods in those raiony that had, in its view, maliciously refused to honor their grain contracts. Any village or kolkhoz caught trading in such goods was blacklisted and prevented from engaging in economic activity with other kolkhozy, villages, and government organizations. ${ }^{130}$

By mid-December 1932, Ukrainian authorities stopped the delivery of manufactured goods to more than eighty raĭony that failed to honor their grain quotas. Molotov believed that stopping the supply of manufactured goods to poorly performing kolkhozy would be an effective form of punishment, as well as an incentive for them to deliver more grain. ${ }^{131}$

The acute food shortage prompted some peasants in Ukraine and the Kuban to attempt to migrate in search of a better life. According to Stalin and Molotov, this migration had been organized by enemies of the Soviet government, such as Socialist Revolutionaries and Polish agents. Stalin and Molotov issued a directive on 22 January that Ukrainian authorities were to take every measure to stop these counter-revolutionary elements from succeeding. In response to this directive, the Ukrainian Politburo issued its own directive on 23 January 1933, which severely restricted access to and increased control of the republic's borders. ${ }^{132}$ 
In the Khortytsia and Molochansk raĭony, Mennonites played important roles in implementing and enforcing these new government procurement demands, restrictive laws, and passport regulations. In Molochansk, for example, I. K. Penner, a Mennonite and communist party member, orchestrated and enforced the government's grain procurements requirements while serving as REC chairman from January to October 1932; Penner was later replaced by the non-Mennonite Wilkel. Under pressure from regional authorities to exceed past procurement quotas for the Molochansk raĭon, both Penner and Wilkel were ruthless in implementing government measures to collect grain, meat, and produce. Penner, for instance, accused both Mennonite and non-Mennonite kolkhoz chairmen of working together with kulaks, ekspertniki, White Guard counter-revolutionaries, and foreign interests to sabotage the government's procurement, collectivization, and industrialization campaigns. ${ }^{133}$

In late 1932, the Khortytsia and Molochansk REC organized troikas (threeperson extrajudicial tribunals) to visit and inspect the kolkhozy. The troikas reported the names of kolkhoz chairmen who were behind in procurement deliveries or who had authorized the release of grain and produce to feed their starving members. REC representatives began appearing at kolkhoz general assembly meetings on a weekly, sometimes daily basis to intimidate and berate the chairmen and members for their procurement shortcomings. Any kolkhoz found to be hiding grain or accused of opposing the government's procurement policy was punished with a penalty fifteen times higher than its monthly quota. If a kolkhoz failed to meet these new penalties, the chairman was ordered to confiscate the private property and livestock of the kolkhozniki to make up the shortfall. If this proved unsuccessful, then the kolkhoz chairman was personally liable. On 23 December 1932, for instance, officials from the Dnipropetrovsk Obispolkom (Oblast executive committee) announced that Molochansk kolkhoz chairmen had until 26 January 1933 to ensure that all procurement requirements were met, failing which the regional prosecutor, Kumpirevich, would have the chairmen arrested and prosecuted in the People's Court. To prevent the falsification of procurement numbers, some village soviets shuffled the chairmen from one kolkhoz to another so that each chairman would be monitoring and reporting on the procurement process at a neighboring kolkhoz. ${ }^{134}$

A kolkhoz that failed to meet government procurement contracts was required to return any advances of seed, equipment, or credit previously received from the state, as well as any food or wages advanced to kolkhozniki. To put additional pressure on kolkhoz chairmen, the REC in Molochansk and Khortytsia published the names of delinquent kolkhozy and their chairmen on the Schwarze Tafel (blacklist) and 
subjected them to ridicule in the local press. The authorities also targeted blacklisted kolkhozy with a series of increasingly repressive measures, including prohibiting the delivery of all consumer goods to these kolkhozy, removing all consumer goods from kolkhoz stores, closing kolkhoz stores, prohibiting kolkhozniki from purchasing goods at other kolkhozy, prohibiting blacklisted kolkhozy from participating in trade with other kolkhozy, and withdrawing all credit to blacklisted kolkhozy. ${ }^{135}$

REC, RPC, and village soviet officials also demanded that kolkhoz activists, as well as WPIC and Komsomol members, become Stürmer for the state and aggressively hunt down caches of hidden or stolen grain on the kolkhozy. This included identifying anyone, including kolkhoz chairmen, suspected of or caught stealing or hiding kolkhoz grain, and ensuring that he or she was expelled from the kolkhoz and brought to trial in the People's Court. ${ }^{136}$ In carrying out this task, the activists, WPIC members, and Komsomol members often claimed administrative powers and responsibilities for managing the affairs of their kolkhozy, thereby undermining the kolkhoz chairman's authority. At a number of Khortytsia and Molochansk kolkhozy, activists usurped control of the executive council and general assembly meetings, and appointed one of their own to chair these meetings. Local authorities often sanctioned this appropriation of power. Consequently, there was little that the chairman could do but rubber-stamp and implement the directives of the activists. In other kolkhozy, the activists determined when the chairman could speak at kolkhoz meetings or if he could attend them at all. The chairman also proved to be a convenient scapegoat for the activists if the kolkhoz fell short of meeting ongoing government procurement demands for grain, meat, and agricultural produce. Because the REC prohibited the recall of chairmen without its approval, the only way that a kolkhoz chairman could escape his duties was if the REC approved the chairman's release from his position or the chairman was expelled from the kolkhoz.

With their newfound authority, kolkhoz activists often took it upon themselves to make decisions on a host of important issues, such as determining how the summer harvest would proceed, whether kolkhozniki would be required to thresh at night or during inclement weather, and under what circumstances kolkhozniki would have to re-thresh straw to obtain additional grain. In January 1933, kolkhoz activists in the Ohrloff (Molochansk) area directed all kolkhozniki to return fifteen percent of their annual food rations to make up for deficiencies in the procurement contracts. At other kolkhozy, the activists ordered the chairmen to direct kolkhozniki to return advances that had previously been paid as annual wages or food rations. ${ }^{137}$

With the help and direction of the REC and village soviets, the activists also organized and conducted surprise raids on kolkhozy to locate hidden or stolen grain in

The Carl Beck Papers in Russian and East European Studies http://carlbeckpapers.pitt.edu | DOI 10.5195/cbp.2015.199 | Number 2305 
kolkhozniki households. The REC authorized activists to conduct such raids, going so far as to sponsor special courses on how to conduct successful grain raids. The REC also encouraged the kolkhoz activists to recruit children, Young Pioneers, and handicapped members in every kolkhoz to help locate hidden caches of grain in the homes of kolkhozniki. These raids were sometimes conducted in conjunction with "red-wagon columns" (trains), which involved the REC and village soviets sending large numbers of local officials with horse-drawn wagons into the countryside to force peasants, including those not in kolkhozy, to surrender their grain at fixed government prices. $^{138}$

A chairman's misdeeds or failures were a convenient pretext for activists to launch unannounced grain raids in a kolkhoz. In January and February 1933, for instance, Mennonite and non-Mennonite activists and Komsomol members at the Rosenort artel (Molochansk) agreed that Mennonite chairman Heinrich H. Epp and his executive had failed to deal with the ongoing problem of kulaks, speculators, and anti-Soviet elements in the kolkhoz stealing and hiding kolkhoz grain. They also accused Epp of failing to lead a proper campaign against kulak sabotage of kolkhoz grain procurements and neglecting to properly prepare for the spring seeding campaign. To punish Epp for his misdeeds, the activists and Komsomol members organized a thorough search for grain throughout the kolkhoz. The consequences for those whose secret stashes of grain were discovered were dire: their names were posted on the Schwarze Tafel as kulaks or ekspertniki and they were expelled from the kolkhoz before being handed over to the OGPU. If a chairman continued to perform poorly, his kolkhoz could expect to be targeted with a flurry of retributive grain raids that were led not only by kolkhoz activists, but also by the OGPU and local WPIC, Komsomol, and CVP cells. ${ }^{139}$

All of these measures - grain raids, increasing procurement demands, harsh government laws, new passport rules, and zealous efforts to appropriate the decisionmaking authority of kolkhoz chairmen-had disastrous consequences for chairmen and their kolkhozy in Khortytsia and Molochansk. In Molochansk, for example, $\mathrm{RCP}$ officials reported that the average kolkhoznik received one or more kilograms of food per day in 1931-32, with kolkhozniki at only eight kolkhozy receiving less than a kilogram of food per day. ${ }^{140}$ By the summer of 1932, however, food rations for kolkhozniki had declined substantially. For instance, the executive at the Rosenort artel determined that the rations for each member would be no more than 250 grams of bread per day. Daily milk allowances for Molochansk kolkhozniki, which were often set at one liter per person in 1930-31, were also drastically reduced. By the fall 
of 1932, the daily milk ration for children at some kolkhozy was half a liter per child, while at other kolkhozy milk was no longer available to children or their parents. ${ }^{141}$

The food crisis in the kolkhozy intensified in 1933. In response, the Molochansk RCP imposed food ration restrictions on kolkhozy and directed chairmen to limit the average food rations for each kolkhoznik to 200 grams of flour per day unless a kolkhoznik exceeded his or her daily work norm, in which case the daily food ration was increased to 250 grams of flour per day. ${ }^{142}$ Desperate Mennonite kolkhozniki resorted to supplementing these starvation rations with other sources of food. Mennonite kolkhozniki in Schöneberg (Khortytsia) subsisted almost entirely on vegetables, while kolkhozniki at a kolkhoz near Halbstadt (Molochansk) ate rotten beets and ears of corn usually set aside for livestock fodder. Members of the Liebenau kolkhoz (Molochansk) lived on turnips, cornstalks, pumpkins, bone meal, thistles, tree bark, and sawdust. Some Mennonite kolkhozniki ate mice, crows, cats, dogs, and diseased livestock. In the Molotschna colony, for example, 755 families ate horsemeat, 469 families ate crows, 344 families ate cats, and 184 families ate dogs between the spring of 1932 and the summer of 1933. The inhabitants of the Wernersdorf kolkhoz (Molotschna) were so hungry that they fought among themselves to determine who would eat the last few cats in the village. ${ }^{143}$ The living conditions in some kolkhozy during this time were arguably no better than those in the worst exile settlements.

Because they could not increase the food rations without the approval of local officials and activists, chairmen were largely powerless to alleviate the food crises in their kolkhozy. Furthermore, kolkhozniki found it increasingly difficult to obtain passports to travel to urbanized regions in the country where jobs and food were more readily available. Even those kolkhozniki who secured passports still had to obtain written permission from the workplace where they hoped to obtain employment, as well as permission from the kolkhoz chairman to leave the kolkhoz. These restrictions on the movement and employment of kolkhozniki made it extremely difficult to escape the collective farm.

Despite these miserable conditions, kolkhoz chairman were still expected to motivate their members to work for the kolkhoz and the state. Some chairmen awarded prizes to the hardest working kolkhozniki. During the 1934 harvest, the chairman of the Khataevich kolkhoz (Khortytsia) offered three prizes of 200 rubles, five prizes of 100 rubles, and two prizes of 50 rubles in cash or in kind to the best Stürmer. ${ }^{144}$ Other chairmen used public praise to inspire their members: they submitted the names of kolkhozniki who earned the most labor days for publication in the local newspaper's honor roll. In early January 1934, for example, Stürmer published a list of the best 
workers at the Bauer kolkhoz (Osterwick, Khortytsia) that included the names of a number of Mennonites. Stürmer also published the names of the best workers in the raion on a list entitled "Stalin's Guard of Honor" and invited them to attend a reception in their honor. To motivate the least productive kolkhozniki to improve, kolkhoz chairmen often published the names of kolkhozniki with the lowest number of labor days on a "lazybones list" in the local press. Newspapers also printed the names of kolkhozniki who had received credit for labor days they allegedly did not deserve or those who had labor days deducted from their records after they were accused of stealing kolkhoz property or committing crimes against the kolkhoz. ${ }^{145}$ In January 1934, for example, the Blumenthal kolkhoz (Molochansk) reported the demerits of the following Mennonites: Elena Friesen received a deduction of sixty labor days for milk theft, Heinrich Kliewer was given a deduction of twenty-five labor days for poor sowing work, and Anna Schulz lost thirty-one days for stealing bread. At the Liebenau kolkhoz (Molochansk), seven kolkhozniki were penalized ten labor days each for allegedly not following the class line and participating in kulak activities. In some cases, the offending kolkhozniki were transferred to the OGPU or People's Court for prosecution. ${ }^{146}$

Expulsion from the kolkhoz was another threat used by kolkhoz chairmen to motivate members to work harder. Kolkhoz chairmen used a variety of charges, including some that were not related to productivity, to justify expulsions. Having kulak parents or connections with the West, for example, were sufficient grounds to expel a member from the kolkhoz. After the "Seven-Eight" Decree was implemented in early August 1932, however, chairmen could expel members on the flimsiest of allegations and trumped-up charges in defense of kolkhoz property. A Molochansk artel expelled a Mennonite dairymaid, for example, after she was accused of taking a small container of milk out of a kolkhoz barn without permission from the administration. The significant increase in the number of kolkhoz fires in 1932-33, whether they involved buildings or crops, also meant an increase in the number of Mennonites who were expelled as arsonists. ${ }^{147}$ As famine conditions reached their worst in late 1932 and early 1933, kolkhoz chairmen and activists at Khortytsia and Molochansk kolkhozy presided over hearings that resulted in the mass expulsion of entire families; eight to ten households were evicted from some kolkhozy every week or so. At the meeting of members of the Rosenort artel (Molochansk) on 3 January 1933, for example, Mennonite chairman Heinrich Epp presided at the disciplinary meeting to expel nine Mennonite families immediately. Less than three weeks later, Epp convened a meeting of the activists of the Rosenort artel where the following resolutions were passed: expel seven Mennonite families immediately; expel four

The Carl Beck Papers in Russian and East European Studies http://carlbeckpapers.pitt.edu | DOI 10.5195/cbp.2015.199 | Number 2305 
Mennonite families and a non-Mennonite German family if they did not deliver stolen grain to the artel in twenty-four hours; expel a Mennonite family and nonMennonite family if they did not deliver stolen grain to the artel in forty-eight hours; and expel three Mennonite families and six non-Mennonite families if they did not deliver stolen grain to the artel in seventy-two hours. For many of these families, expulsion was tantamount to a death sentence because any member forced to leave the kolkhoz was required to forfeit all labor days that he or she had earned, as well as any interest in kolkhoz livestock, crops, or future earnings. ${ }^{148}$ Without property or money, and prohibited from joining other kolkhozy or moving to another region, most expelled kolkhozniki found it impossible to survive on their own.

Such mass expulsions did not always result in a significant decline in the population of Khortytsia and Molochansk kolkhozy, however. This is because the expulsions coincided with a spike in the number of admission requests from desperate, non-collectivized peasants who now wanted to join a kolkhoz. In late spring 1933, for example, the chairman of Sovset artel (Blumenort, Molochansk) received eight to ten membership applications a week immediately prior to the harvest of the winter crops. ${ }^{149}$

In 1933, local officials ordered kolkhoz chairmen and activists to punish any kolkhoznik who obtained food or monetary aid from the West. In the late 1920s and early 1930s, Mennonite family members and relief organizations in North America and Germany had begun sending parcels of food and letters containing money to Khortytsia and Molochansk Mennonites. Between 1931 and 1934, however, Soviet censors made a concerted effort to stop this foreign aid by confiscating foreign parcels and letters or imposing prohibitive fines on their recipients. Despite the efforts of censors, Mennonite kolkhozniki continued to receive foreign currency in 1932-33, and often used the money to purchase food illegally on the black market or legally at state-operated Torgsin stores that sold food, clothing, and consumer commodities to anyone in exchange for foreign currency, gold or jewelry. After Hitler became Chancellor of Germany in January 1933, local authorities were convinced that German aid was a Nazi attempt to embarrass and subvert Soviet authority; anyone who received German aid was suspected of being a Hitlerite or Nazi agent. Molochansk RCP officials also blamed German consulates in Ukraine for inciting this Nazi agitation in Mennonite-populated villages and for facilitating more than 40,000 Nazi parcels delivered to pro-Nazi households in Molochansk between April 1933 and August 1934. ${ }^{150}$ To flush out these Nazi agents, kolkhoz chairmen and activists forced members to disclose any foreign aid they received, conducted searches of households suspected of receiving Hitlerist aid, denounced 
any kolkhoznik who received foreign aid, and ordered all foreign aid to be sent back to Germany to feed oppressed and starving workers. Kolkhoz chairmen prohibited kolkhozniki from attending Torgsin stores, and in some cases expelled kolkhozniki accused of receiving money or goods from outside the USSR. ${ }^{151}$

\section{Disciplining and Expelling Mennonite Kolkhoz Chairmen}

As was the case with any kolkhoz member, no kolkhoz chairman was safe from discipline, dismissal, or expulsion. But rarely was a kolkhoz chairman punished, permitted to resign, recalled, dismissed or expelled without the prior approval of the REC, RCP, or WPIC. Local state or party officials almost always had the final say in such matters. ${ }^{152}$

It was unusual but not impossible for a kolkhoz chairman to be granted a temporary leave of absence due to extenuating circumstances, such as a serious health condition. In February 1930, for example, Heinrich H. Goossen, chairman of the cooperative at Blumstein (Molochansk), submitted his resignation due to illness. The members of the artel initially refused Goossen's resignation, but eventually granted him a three-month leave of absence based on the recommendation of Goossen's doctor. It is not clear, however, under what circumstances a chairman was allowed to tender his permanent resignation, as permission was so rarely granted by the kolkhoz. One of the few instances occurred in December 1931, when the executive council of the Tiege artel (Molochansk) accepted the resignation of their kolkhoz chairman; unfortunately, the available documentation does not indicate why he was allowed to resign. ${ }^{153}$

It was common for local authorities and kolkhozniki to discipline chairmen who were performing poorly or involved in scandalous affairs. Discipline typically included embarrassment by public scolding at a REC or village soviet meeting, inclusion of the name of the chairman on the Schwarze Tafel, or publication of poison-pen letters in the local newspapers. Punishment also took the form of decreasing or suspending a chairman's wages or labor days or increasing the taxes or procurement quotas of his kolkhoz. ${ }^{154}$

Other forms of discipline experienced by Mennonite kolkhoz chairmen in Khortytsia and Molochansk included dismissal, recall, expulsion, imprisonment, and exile. In fact, many chairmen were dismissed, recalled, or expelled within a year of their appointment to the post. Heinrich Epp, for example, served as secretary 
of the Rosenort artel (Molochansk) in 1931-32 and was appointed its chairman in December 1932, only to be recalled by the Rosenort kolkhozniki six months later because of weak leadership and poor performance. With time, more and more of these Mennonite chairmen were replaced by non-Mennonites, often Ukrainians, who were presumably viewed by local authorities as more suitable. ${ }^{155}$

There was also at least one case of chairmen being recalled en masse. In late 1933 local officials in Molochansk initiated a raĭon-wide recall campaign demanding that kolkhozniki denounce their chairmen for failing to properly implement the 1933 grain procurement campaign and for assisting class enemies in their sabotage of Soviet agriculture. The result of this campaign was that every Molochansk kolkhoz chairman was removed from his position and replaced with a newly elected, often non-Mennonite chairman by the end of January 1934. ${ }^{156}$

Individual kolkhoz chairmen were also dismissed or expelled because they were deemed to be kulaks, ekspertniki, wreckers, agitators, or saboteurs. In spring 1930, the chairman of the Khortytsia raion WPIC determined that Isaak J. Rempel, the Mennonite chairman of the Internatsional artel (Nieder Khortytsia), was an agitator who had to be removed immediately. ${ }^{157}$ The number of chairmen who were dismissed because of their counter-revolutionary activities increased as the famines of 1932-33 intensified. Their inability to meet the increasing targets of state procurement contracts and quotas for their kolkhozy qualified them as class alien elements that had to be removed. In December 1932, for example, the Mennonite chairman of the Rosenort artel (Molochansk), Johann D. Penner, was dismissed because of allegations that he was a kulak and speculator who actively agitated against the grain campaign. ${ }^{158}$ A month later, Heinrich H. Hildebrand, a party candidate and Mennonite chairman of the Wernersdorf kolkhoz (Molochansk), was accused of participating in kulak sabotage and stealing kolkhoz grain for self-enrichment purposes. Hildebrand was expelled not only from the party, but also from the kolkhoz, and was ordered to surrender to the People's Court for trial. ${ }^{159}$

When a chairman was unceremoniously removed from his post, it was not unusual for local officials to hastily appoint an interim chairman (usually a local official from the village soviet) to impose order and discipline, and improve the kolkhozy's performance until a permanent kolkhoz chairman was appointed. One of these interim chairmen was the Mennonite David K. Unruh, a former hospital worker who became a party candidate in 1932. Unruh had little farming experience, but his leadership position on the Ohrloff (Molochansk) village soviet (he was chairman in 1930 and 1932-33) qualified him to serve as interim chairman for a number of kolkhozy in the village soviet: the Ohrloff SOZ in 1930-31 and again in early 1933; 
the Tiege kolkhoz on a number of occasions between 1930 and 1932; the Rosenort kolkhoz in 1932; and the Nadezhda artel (Ohrloff) in late 1932-33. As an interim chairman, Unruh had a reputation for motivating poorly performing kolkhozy to improve their delivery of procurement contracts. How was Unruh rewarded for his efforts? In mid 1934, he was accused of supporting the Mennonite Selbstschutz during the civil war, abruptly removed from his post as chairman of the Nadezhda kolkhoz, and purged from the party in $1934 .{ }^{160}$

Hitler's rise to power in Germany in 1933 increased the pressure and frenzy to identify and expel counter-revolutionary kolkhoz chairmen. By mid 1933, Khortytsia and Molochansk officials were routinely accusing ethnic German kolkhoz chairmen of receiving aid from Nazi-sponsored relief organizations, becoming Nazi sympathizers, or assisting Hitlerites and Nazi agents in undermining the work of the kolkhozy. ${ }^{161}$ According to one Molochansk RCP report prepared in early 1934, "there had now been intensive work to identify counter-revolutionary and fascist elements in the Molochansk raion along nationalist, that is, German lines. These nationalists were fighting against Marxist-Leninist ideology; among the nationalist elements there were also Hitler's agents who ... are working in the religious leadership and cults." ${ }^{162}$ Another RCP report claimed that up to 90 percent of the population in some German-populated villages were kulaks who were leading the attacks of international German fascism against Soviet Ukraine. The party now had to undertake an aggressive campaign of "national cultural construction in these areas to defeat fascist and counter-revolutionary forces." 163

The "national cultural construction" campaign did not occur in a vacuum: it came near the end of a nation-wide chistka initiated by the Communist Party in January 1933. Party membership had increased from 1.5 million to 3.5 million between 1929 and 1933, and in late 1932, some party members were concerned that the mass admissions had led to an influx of "alien elements," "double dealers," and individuals who were "insufficiently stable" or "politically almost illiterate." By the end of 1934, the party's specially formed Central Purge Commission had expelled approximately 18 percent of the party membership. As was the case with the 1929 chistka, the 1933-34 chistka was not confined to party organizations, but inspired local authorities to initiate chistki in non-party bodies including raĭon soviets, village soviets, local government bodies, and kolkhozy. ${ }^{164}$

The 1933-34 chistki and the government's "national cultural construction" campaign in German-speaking villages initiated a new wave of terror in Khortytsia and Molochansk. This was because one of the primary goals of these campaigns was the immediate expulsion of all "fascist, counter-revolutionary, White Guard,

The Carl Beck Papers in Russian and East European Studies http://carlbeckpapers.pitt.edu | DOI 10.5195/cbp.2015.199 | Number 2305 
and Petlyurist agents" who had ostensibly infiltrated every level of the raiony. ${ }^{165}$ Between January and July 1934, for example, the Molochansk RCP organized chistka commissions (troikas of three high-ranking party members) that conducted public show trials in the villages and kolkhozy to root out fascists and class alien elements in Molochansk party organizations, state organizations, Komsomol cells, village soviets, activist organizations, CVP, and WPIC. By August 1934, the chistka commissions had succeeded in expelling fifty-three party members and forty-seven candidates from the Molochansk party organization alone. ${ }^{166}$ Kolkhoz activists were also not spared; almost every Molochansk kolkhoz, for instance, saw the expulsion of one or more of its executive council members or activists in 1934. At the same time, the OGPU began targeting German-speaking groups as "enemy nations" throughout Ukraine, and initiated "border-cleansing operations" to remove populations sympathetic to Hitler from the western border areas of the country. ${ }^{167}$

Mennonite kolkhoz chairmen were prime targets for these cleansing campaigns. Even before the chistka commissions began focusing on the kolkhozy, the Molochansk REC had concluded that there were still at least twenty-three kolkhoz chairmen in the raĭon who belonged to class-alien elements in the spring of 1934, and that the kolkhozy at Schönau, Rückenau, Lichtfeld, Münsterberg, Ohrloff, Gnadenfeld, and Alexandertal were thoroughly infiltrated with kulaks and fascists. ${ }^{168}$ Mennonite kolkhoz chairmen were now accused of committing a wide range of crimes against the state, some of which included the following: being a kulak, ekspertnik, White Guardist, fascist agent or class alien; collaborating with such enemies of the state; having parents who were kulaks or ekspertniki, or who had a large farming operation prior to the Bolshevik revolution; being married to a kulak, ekspertnik or Nazi agent; failing to implement the decisions of the party or the state; failing to honor government procurement contracts; sabotaging kolkhoz property or agricultural plans; committing excessive wastefulness on the kolkhoz; failing to implement "Bolshevik criticism and self-criticism" to improve kolkhoz performance; failing to implement socialist forms of labor; and receiving Nazi aid. Some Mennonite chairmen were also attacked for participating in activities such as corresponding with relatives in the West or purchasing goods at a Torgsin store, which the state now deemed counter-revolutionary.

Some of the Mennonite kolkhoz chairmen who were expelled from Molochansk kolkhozy included the following: Jakob P. Sudermann (Rote Fahne, Altonau), an alleged White Guardist and kulak with connections to America, whose parents had a large prerevolutionary farming operation and whose wife was also accused of being a kulak; Gossen (Blumenort artel), a suspected White Guardist; Derksen (Schonau 
kolkhoz), a former White Army officer who was accused of collaborating with kulaks to reduce the growth of the kolkhoz breeding herd and squander productive cattle; J.J. Gossen (Blumstein artel), a class alien element who had past associations with the White Army and had ostensibly undertaken destructive work on the artel; and Kopp (Stalino Reichenfeld kolkhoz), who had allegedly received fascist aid. ${ }^{169}$

Even Mennonite kolkhoz chairmen who were communist party members or candidates, and had survived the 1933-34 chistki, were not safe from attack. This was the experience of Nikolai N. Boldt, a communist party member and kolkhoz chairman at Hierschau (Molochansk). Boldt was expelled from both the party and the kolkhoz in early 1935 after the Molochansk party organization determined that Boldt was guilty of a long list of crimes, including initiating measures to sabotage the super sowing campaign of 1934, ensuring that the weeding of the fields in 1934 was very slow, delaying the 1934 harvest, facilitating connections with foreigners, purchasing goods at theTorgsin store, and receiving Nazi aid. ${ }^{170}$ It is not clear what ultimately happened to Boldt and other purged chairmen.

The chistki of so many Mennonite kolkhoz chairmen in 1933-34 marked an important shift in the management of Mennonite kolkhozy in Khortytsia and Molochansk: an increasing number of non-Mennonites became the chairmen of Mennonite-populated kolkhozy. In Khortytsia, less than half of all Mennonitepopulated kolkhozy were managed by Mennonite kolkhoz chairmen by March of 1934, and by late 1934, there were only a handful of Mennonites managing kolkhozy in Molochansk. ${ }^{171}$

\section{Some Final Observations}

Mennonite kolkhoz chairmen played a key role in the collectivization of Khortytsia and Molochansk. In many cases, these Mennonites were selected for the position of chairman not because of their past agricultural expertise or success, but because they were members of socially friendly or socially neutral classes, represented the dominant ethnic group in the German national raiony, or had demonstrated loyalty to the regime through their connections to the party or past service to the state. Available archival documentation does not explicitly reveal what motivated Mennonites to serve as kolkhoz chairmen, but there are a number of possible reasons why some Mennonites agreed to do so. Upward social mobility was certainly one motivating factor. The position of kolkhoz chairman was largely 
administrative, not as physically demanding as other positions on the kolkhoz, and a potential stepping-stone to higher social status and better government positions in the raĭon. The position usually came with higher wages, better housing and more opportunities for education than were typically available to the average kolkhoznik. Some Mennonites may have sought the position of chairman because they had leadership skills and felt a duty to serve their community, or because they were attracted to the power and prestige that came with the office. There may also have been some Mennonites who accepted the post of chairman in the belief that they and their families would be immune from dekulakization. Still other Mennonites may have had no desire or ambition to become a kolkhoz chairman, but were elected to the post by fellow kolkhozniki or appointed by local officials. These individuals served because of social obligation, intimidation or fear rather than desire or ambition.

Regardless of what motivated Mennonites to assume the position of kolkhoz chairman, it is clear that the overwhelming majority of them were either not up to the task or were doomed to fail from the outset because of external factors. Many Mennonite kolkhoz chairmen did not have the skills or experience to operate a large agricultural enterprise such as a kolkhoz. While these chairmen may have met the government criteria of class consciousness and ethnicity, they were typically some of the poorest, least successful farmers in their villages. In addition to weak farming skills, almost all chairmen lacked the basic leadership and management skills that were essential to supervising an agricultural enterprise with hundreds of members and thousands of hectares of land. Most were in the position of kolkhoz chairman for less than a year before they were removed; at some kolkhozy, the chairmanship was like a revolving door, with a new chairman being elected every few months. In these circumstances, it was impossible for a chairman to develop any competency, expertise, or ease with the position. Even for Mennonites who did have some aptitude for the position, inadequate government training and support made it difficult to succeed. Without precedents to follow, Mennonite kolkhoz chairmen struggled to implement the government's contradictory and unrealistic policies, which resulted in costly and sometimes deadly mistakes.

The collectivization policies of the Soviet regime also contributed to the failure of Mennonite kolkhoz chairmen. An odd mixture of utopian and dystopian elements, the regime's collectivization policies gave little consideration to viable agricultural practices and economic principles, the practical realities of the Soviet countryside, or the long-term welfare of the Soviet peasantry. Instead, the policies focused on realizing a Stalinist vision of collectivized agriculture, a vision that often necessitated the abandonment of effective agricultural practices and the implementation of 
untried, pro forma socialist policies designed to maximize the state procurement of agricultural produce. The primary role of the kolkhoz chairman was to turn this vision into reality and to ensure that state procurement requirements were exceeded, even if this was detrimental to the interests of the kolkhoz and its members. These government expectations put the kolkhoz chairman in an irreconcilable conflict of interest with his kolkhoz because the chairman's duties to the regime always trumped his duties to the kolkhoz membership. In this world of divided loyalties, the policies of the regime made it impossible for the chairman to act in the best interests of his kolkhoz, thus endangering the viability of the kolkhoz.

What also proved to be enormously frustrating for kolkhoz chairmen was the unplanned, reckless manner in which the Stalinist leadership implemented collectivization policies, often with little or no regard for the impact that these policies would have on the kolkhozy, the kolkhoz chairmen, or Soviet agriculture. For example, the publication of Stalin's article "Dizzy with Success" not only permitted millions of kolkhozniki to reclaim their property and leave the kolkhozy, but also sent mixed messages to the countryside about the government's commitment to collectivization, making it extremely difficult for kolkhoz chairmen to find the manpower to complete the spring and summer field work in 1930. The regime continued to introduce ad hoc, often contradictory, policies throughout the early 1930s, making it impossible for kolkhoz chairmen to develop any meaningful longrange plans for their kolkhozy. Consequently, chairmen often had to manage their kolkhozy reactively or in an improvised manner which had disastrous long-term consequences for Khortytsia and Molochansk kolkhozy.

The government's sporadic dekulakization campaigns further impeded the ability of Mennonite kolkhoz chairmen to do their job. The arrest, imprisonment, exile, or execution of the most successful Mennonite kulak and ekspertnik farmers in 1929-30 resulted in the irreplaceable loss of agricultural knowledge and expertise that would have proved invaluable to kolkhoz chairmen. Kolkhoz chairmen suffered another disastrous blow when the government initiated policies to dekulakize the kolkhozy in early 1931; this depleted much needed manpower in the kolkhozy, distracted kolkhozniki from performing their agricultural duties, and jeopardized the 1931 harvest. Such policies convinced some that it was Moscow's leaders, not the kulaks, who were the bigger threat to Soviet agriculture.

The Soviet leadership's role in impeding agriculture was obvious to kolkhoz chairmen in late 1932 and early 1933, when the regime implemented some of its most repressive grain collection and agricultural policies. This essentially undercut the ability of the peasantry to produce the agricultural products demanded by the 
state. Kolkhoz chairmen were on the front lines of this grain collection war, acting as pawns in many of the government's ill-conceived, rapacious, and deadly policies. In this environment, it was impossible for kolkhoz chairmen to succeed; many lost their positions and ultimately their lives as a result.

The attitudes and policies of local officials in Khortytsia and Molochansk also made it exceedingly difficult for Mennonite kolkhoz chairmen to meet government expectations. The unrealistic calendar, work and agricultural plans of local authorities, combined with unproven socialist agricultural techniques and herculean procurement contracts imposed requirements that kolkhoz chairmen often found impossible to meet and impeded them from applying practical solutions to the day-to-day challenges of managing a large agricultural enterprise. MTS officials contributed to the frustration of kolkhoz chairmen by repeatedly failing to deliver promised tractor and agricultural services in a timely manner; consequently, important kolkhoz agricultural work was performed late, partially, or not at all. MTS and local authorities also put enormous pressure on kolkhoz chairmen to increase the amount of cultivated land in their kolkhozy, forcing kolkhoz chairmen to expend valuable kolkhoz resources on large tracts of poor or infertile land. Rather than supporting the chairmen to make it possible to run efficient and productive kolkhozy, the attitudes and policies of local officials created insurmountable obstacles for most kolkhoz chairmen, thus ensuring their failure.

Local officials often pointed to kolkhoz chairmen as the scapegoats for many of the failures of collectivization. This manifested itself in many ways, including spying on chairmen, berating and embarrassing them in newspapers and public meetings, and expelling kolkhoz chairmen without notice. Such behavior created widespread suspicion and paranoia that often drove discouraged chairmen to devote much of their creativity, ingenuity, and energy to meeting the outlandish requests of local officials, instead of solving important agricultural and economic problems facing their kolkhozy. Local officials also implemented policies that emasculated the authority of kolkhoz chairmen, such as when officials encouraged activists to challenge and usurp the decisions and policies of the kolkhoz chairmen during the famines of 1932-33. These measures made it impossible for many chairmen to lead and manage their kolkhozy with any credibility or authority; even the most patriotic kolkhoz chairmen must have lost confidence not only in themselves but also in the local leadership.

In actuality, some Mennonite kolkhozniki were not motivated to see their chairman or their kolkhoz succeed. The devastation and anarchy of World War I, the Bolshevik Revolution, the Russian Civil War, and the 1921-22 famine had shattered 
the lives of most Mennonites and fractured the economic, social, and political ties that had united Mennonite communities. These experiences alienated the Mennonite communities from the Bolshevik regime. Khortytsia and Molochansk were beginning to recover from these destructive events when the Soviet regime dekulakized and forcibly collectivized their communities. Many Mennonites who surrendered their property to the local kolkhozy and joined on as members did so not because they believed the Bolshevik propaganda about collectivization, but because they had just witnessed the dekulakization of their neighbors and friends, and wanted to avoid dekulakization at all costs. They relinquished their economic, political, religious, and social independence in exchange for some degree of security from dekulakization. They soon discovered, however, that kolkhozniki could also be dekulakized, that their kolkhozy offered little protection from potential repression, and that their chairmen often did little to protect kolkhozniki from exploitation.

The regime hoped that the dekulakization and removal of wealthier farmers and religious leaders would prompt the peasants to view the kolkhoz chairmen as the new leaders of their communities. In reality, however, most Mennonite kolkhozniki felt resentment and hostility toward the kolkhoz chairman, even if the chairman was a family member or neighbor. They viewed him as an agent in the service of the state rather than the kolkhoz membership. Many kolkhozniki had little confidence in the agricultural expertise of the kolkhoz chairman and harbored suspicions about the chairman's qualifications and motives; they actively resisted his policies, reported his failures and vices in poison-pen letters published in local newspapers, and often worked to undermine his authority or remove him from his position. The lack of respect that kolkhozniki exhibited toward the chairman was often reciprocated, and sometimes manifested itself in a chairman abusing his power and authority for personal benefit. Where this abuse was frequent and pervasive, a toxic atmosphere of acrimony, suspicion, and deceit permeated the kolkhoz and undoubtedly affected morale and productivity.

Finally, anti-German hostility and anti-sectarianism also made it enormously difficult for Mennonite kolkhoz chairmen to succeed. Non-Mennonite officials and kolkhozniki were suspicious of Mennonite chairmen, and Mennonite chairmen had to avoid the perception that they were playing favorites. This antipathy toward Germanspeaking chairmen intensified after Hitler became Chancellor of Germany, prompting local authorities to accuse Mennonite chairmen and kolkhozniki of receiving Nazi aid, working as Nazi agents in the kolkhoz, and facilitating the destruction of Soviet agriculture. The hostility became increasingly palpable and culminated in the mass expulsion of Mennonite kolkhoz chairmen during the 1933-34 chistki and

The Carl Beck Papers in Russian and East European Studies http://carlbeckpapers.pitt.edu | DOI 10.5195/cbp.2015.199 | Number 2305 
the nationalist reconstruction campaign of 1934. A large number of chairmen were removed from their positions not because of what they failed to accomplish, but because of who they were: German-speaking Mennonites. In this respect, Mennonite ethnic and sectarian identity proved to be a liability for kolkhoz chairmen; it resulted in additional challenges and difficulties that most non-Mennonite kolkhoz chairmen in the Molochansk and Khortytsia raĭony did not encounter. Kolkhoz chairmen who were Mennonites were subjected to greater supervision by local officials, their kolkhozniki were often targeted with more intense administrative and dekulakization measures, and their kolkhozy were forced to surrender large tracts of land in order to facilitate better relations between the German and the Ukrainian populations. The culmination of these discriminatory practices occurred in 1933-34 when local officials now accused Mennonite-populated kolkhozy of serving as sanctuaries for Hitler's agents and implemented harsh measures to cleanse them of counterrevolutionary elements.

So were there any advantages to having a Mennonite as chairman of the kolkhoz? While Mennonite kolkhozniki may have questioned a Mennonite chairman's motives for colluding with the Soviet state, it was advantageous to work under a chairman who spoke their language, understood their cultural and religious sentiments, and was perceived to be more likely to advocate on their behalf. Despite their mistrust and suspicion of kolkhoz chairmen, Mennonite kolkhozniki still preferred to have a fellow Mennonite at the helm rather than a Ukrainian or Russian.

On many levels, the job of kolkhoz chairman was one of the most unenviable in the Soviet countryside. Mennonite kolkhoz chairmen tried to do their best in very difficult circumstances, but they were in an impossible situation. As government representatives, they had to implement, justify, and defend government policies, regardless of the consequences for their fellow Mennonites. They also had to make life-and-death decisions, such as determining food rations for members during the famine; identifying alleged kulaks, ekspertniki, counter-revolutionaries, and Hitlerites in the kolkhoz; and directing the expulsion of fellow kolkhozniki. Mennonite kolkhoz chairmen were thus catalysts of rapid and unprecedented change in Mennonite communities: they helped to dissolve many of the traditional social, religious, economic, and political foundations, and in doing so assisted in the destruction of their communities.

Kolkhoz chairmen became de facto wardens of their kolkhozy after the "Seven-Eight" Decree, new passport rules, and other government directives restricting mobility that came into place in late 1932. These measures effectively prevented both Mennonite and non-Mennonite kolkhozniki from leaving the kolkhozy to find food 
in other regions of the country. But in other respects, Mennonite kolkhoz chairmen were also prisoners of their kolkhozy. Chairmen had limited control over their public and private lives, and even less control over their future destiny. Chairmen lived in constant fear of their political masters, government informers inside and outside the kolkhozy, and their own kolkhozniki. On many levels, the people above and below them determined the course of their lives. Many chairmen attempted to resign from their office, but the regime made this impossible without its permission. Chairmen were essentially expendable pawns who could be branded as kulaks, ekspertniki, counter-revolutionaries, saboteurs, wreckers, class aliens, White Guardists or fascist agents, and removed, either by higher officials or by their fellow kolkhozniki, without a moment's notice.

To what extent Mennonite kolkhoz chairmen participated in acts of resistance against the regime is not entirely clear from the available documentation. It is evident that some Mennonite chairmen did not enforce government directives in the kolkhoz as strictly as others; some kolkhoz chairmen also permitted greater religious activity in their kolkhozy and turned a blind eye to kolkhozniki who broke kolkhoz rules or received aid from abroad. Unfortunately, the extant personal papers of these chairmen do not convincingly declare that these were deliberate acts of opposition to the regime.

And what was the experience of the dwindling number of Mennonite kolkhoz chairmen who somehow retained their positions through the 1932-33 famine, the 1933-34 chistki and the "national cultural construction" campaign? They faced increasing anti-German, anti-sectarian hostility, which in subsequent years put them at risk for repression, exile, or even death, but that dark future is beyond this study's focus. ${ }^{172}$ 


\section{ENDNOTES}

1. In most of their official and private correspondence, Mennonites in Soviet Ukraine used either the German or Russian language. For this reason, all other Slavic terms used in this study will be in Russian.

2. Menno, "Schicksal, Mein Schicksal!" Stürmer (hereafter ST) Khortytsia, Ukraine, 10 July 1934, 2. My use of the term "Mennonite" includes ethnic Mennonites, whether they belonged to a Mennonite church or not.

3. R.W. Davies, The Soviet Collective Farm, 1929-1930 (London: Macmillan Press, 1980), 56; Sheila Fitzpatrick, Stalin's Peasants: Resistance and Survival in the Russian Village After Collectivization (New York: Oxford University Press, 1994), 185; Lewis Siegelbaum and Andrei Sokolov, Stalinism as a Way of Life (New Haven: Yale University Press, 2004), 49; Mary Allerton Kilbourne Matossian, The Impact of Soviet Policies in Armenia (Leiden: E.J. Brill, 1962), 102; Karl Eugen Wädekin, Agrarian Policies in Communist Europe: A Critical Introduction (Totowa, NJ: Allenhead Usmand \& Co, 1982), 19; Lynne Viola, Peasant Rebels under Stalin: Collectivization and Culture of Peasant Resistance (New York: Oxford University Press, 1996), 224; Stephen Merl, Bauern unter Stalin: Die Formierung des sowjetischen Kolchossystems, 1930-1941 (Berlin: Duncker \& Humbolt, 1990); Stephan Merl, "Social Mobility in the Countryside," in Social Dimensions of Soviet Industrialization, eds., William G. Rosenberg and Lewis H. Siegelbaum (Bloomington: Indiana University Press, 1993), 49.

4. The Mennonite population in Ukraine numbered just over 56,800 in the mid 1920s. V. I. Marochko, ed., Sil's'kohospodars'kyॅ soiuz nashchadkiv hollands'kykh vykhodtsiv na Ukraïni (1921-1927): zbirnyk dokumentiv i materialiv (Kyïv: Instytut istoriï Ukraïny, Natsionalna akademiia nauk, Ukraïny, 2000), 78.

5. Peter M. Friesen, The Mennonite Brotherhood in Russia (1789-1910). Translated by J.B. Toews, Abraham Friesen, Peter J. Klassen, Harry Loewen, et al. (Fresno, CA: Board of Christian Literature, General Conference of Mennonite Brethren Churches, 1980), 3, 29-40; Adolf Ehrt, Das Mennonitum in Rußland von seiner Einwandering bis zur Gegenwart (Berlin-Leipzig: Julius Beltz, 1932), 1. 
6. Terry Martin, "The Russian Mennonite Encounter with the Soviet State, 1917-1955" Conrad Grebel Review 20, no.1 (Winter 2002), 10.

7. Sheila Fitzpatrick, "The Problem of Class Identity in NEP Society," in Russia in the Era of NEP, eds. Sheila Fitzpatrick, Alexander Rabinowitch and Richard Stites (Indiana: Indiana University Press, 1991), 25; Sheila Fitzpatrick, "Ascribing Class: The Construction of Social Identity in Soviet Russia," Journal of Modern History 65, no. 4 (December 1993): 749.

8. David G. Rempel with Cornelia Rempel Carlson, A Mennonite Family in Tsarist Russia and the Soviet Union 1789-1923 (Toronto: University of Toronto Press, 2002), 209; John B. Toews, ed., The Mennonites in Russia, 1917-1930: Selected Documents, (Winnipeg, MB: Christian Press, 1975), 23.

9. Martin, "The Russian Mennonite Encounter with the Soviet State," 18; Toews, Selected Documents, 23, 296.

10. Philip Walters, "A Survey of Soviet Religious Policy,” in Religious Policy in the Soviet Union, ed. Sabrina Petra Ramet, (Cambridge: Cambridge University Press, 1993), 6.

11. Joshua Rothenberg, "The Legal Status of Religion in the Soviet Union," in Aspects of Religion in the Soviet Union: 1917-1967, ed. Richard H. Marshall (Chicago: University of Chicago Press, 1971), 63; David G. Rempel with Cornelia Rempel Carlson, A Mennonite Family in Tsarist Russia and the Soviet Union 1789-1923 (Toronto: University of Toronto Press, 2011), 254.

12. Andrew Sorokowski, "Church and State, 1917-64," in Candle in the Wind: Religion in the Soviet Union, ed. Eugene B. Shirley Jr., and Michael Rowe, (Washington: Ethics and Public Policy Center, 1989), 29; Marite Sapiets, "Antireligious Propaganda and Education," in Candle in the Wind, 93; Gerhard Schroeder, Miracles of Grace and Judgment, (Lodi, CA: By the Author, 1974), 168, 235, 243; Alexander Fodor, A Quest for a Non-Violent Russia: The Partnership of Leo Tolstoy ad Vladimir Cherkov (Lanham, MD: Ethics and Public Policy Center, 1989), 168; Andrei I. Savin, “'Divide and Rule': Religious Policies of the Soviet Government and Evangelical Churches in the 1920s," trans. Walter Sawatsky, Religion in Eastern Europe, XXXI, no. 1 (February 2012), 3. 
13. John B. Toews, Lost Fatherland: The Story of Mennonite Emigration from Soviet Russia (Scottdale, PA: Herald Press, 1967), 76; B. B. Janz, "Zweite Reise nach Moskau," in The Mennonites in Russia from 1917 to 1930, 100; Marochko, Sil's'kohospodars'kyı soiuz, 78, 120.

14. Derzhavnyi arkhiv Zaporiz'koi oblasti (hereafter "DaZo"), fond R-235, opis 1, sviazka 765 (hereafter DaZo: R-235/1/765); DaZo: R-235/4/62; R-235/4/56; R-235/1/751; R-235/1/753; R-235/4/56; R-235/4/367; R-1429/1/12; R-235/4/111; Marochko, Sil's'kohospodars'ky soiuz nashchadkiv hollands'kykh vykhodtsiv na Ukraïni, 201, 207, 214, 252; John B. Toews and Paul Toews, eds. Union of Citizens of Dutch Lineage in Ukraine (1922-1927): Mennonite and Soviet Documents (Fresno, CA: Center for Mennonite Brethren Studies, 2011), 331; A. A. Töws, Mennonitsche Märtyrer (Winnipeg, MB: By the Author, 1949), 274.

15. Terry Martin, The Affirmative Action Empire: Nations and Nationalism in the Soviet Union, 1923-1939 (Ithaca: Cornell University Press, 2001), 12, 20.

16. Meir Buchsweiler, Volksdeutsche in der Ukraine am Vorabend und Beginn des Zweiten Weltkriegs- ein Fall doppelter Loyalität (Gerlingen: Bleicher, 1984), 147; "Der neubegründete Molotschansker Rayon," Der Bote (hereafter DB), Winnipeg, MB, 3 January 1929, 3; M.I. Panchuk, O. P. Koval'chuk, and Bohdan Volodymyrovych Chyrko, Natsional'ni menshyny v Ukraïni, 1920-1930-ti roky: istoryko-kartohrafichnyı atlas (Kyïv: Chetverta khvylia, 1996), 63; DaZo: R-235/2/144; PR-226/1/32; R-286/1/115; R286/1/166.

17. In the fall of 1930 , the Khortytsia raion was absorbed into the Zaporizhia city soviet. DaZo: R-235/1/757; R-235/1/808; Buchsweiler, Volksdeutsche, 148.

18. Oblpartarkhiv Zaporiz'koho obkomu KPU (hereafter "OZoKPU”): fond 7, opis 1 , sviazka 138 (hereafter OZoKPU: 7/1/128).

19. R.W. Davies, Mark Harrison and S.G. Wheatcroft, eds., The Economic Transformation of the Soviet Union, 1913-1945 (Cambridge: Cambridge University Press, 1994), 62, 111; Lynne Viola, V. P. Danilov, N. A. Ivnitskii and Denis Kozlov, eds., The War Against the Peasantry, 1927-1930 (New Haven: Yale University Press, 2005), 17. 
20. V. P. Danilov, R.T. Manning, L. Viola et al., eds., Tragediia sovetskoú derevni: kollektivizatsiia i raskulachivanie: dokumenty i materialy $v 5$ tomakh, 1927-1939. 5 vols. (Moskva: Rossiǔskaia polit. entsiklopediia, 1999-2006), tom 1:111, 119, 136, 141, 231; Lynne Viola, The Unknown Gulag (Oxford: Oxford University Press, 2007), 16.

21. I.V. Stalin, Sochineniia. 13 vols. (Moskva: Gos. izd-vo polit. lit-ry, 1946-51), $12: 167$.

22. Danilov, et al., Tragediia sovetskoŭ derevni, tom 2: 85; Iu. N. Afanas'ev, V. P. Kozlov, et al., eds., Istoriia stalinskogo Gulaga: konets 1920-kh-pervaia polovina 1950-kh godov: sobranie dokumentov v semi tomakh. 7 vols. (Moskva: ROSSPE்N, 2004-05), tom 1:105; tom 5:107, 136.

23. DaZo: R-673/4/5; R-9/879/41; R-235/3/40; R-235/1/756; R-235/3/23; R-235/4/110; Danilov, et al., Tragediia sovetskoŭ derevni, tom 2:130; C. C. Peters, ed., Vor den Toren Moskaus: oder Gottes Gnaedige Durchhilfe in Einer Schweren Zeit (Yarrow, BC: Columbia Press, 1960); Andrej Savin, Etnokonfessiia v Sovetskom gosudarstve: Mennonity Sibiri v 1920-1930-e gody: emigratsiia i repressii: dokumenty i materialy (Novosibirsk: POSOKH, 2009), 250; Harvey L. Dyck, "Collectivization, Depression and Immigration, 1929-1930," in Empire and Nations: Essays in Honour of Frederic H. Soward, eds. Harvey L. Dyck and H. Peter Krosby, (Toronto: University of Toronto Press, 1969), 158-59; Colin P. Neufeldt, "The Flight to Moscow, 1929: An Act of Mennonite Civil Disobedience," Preservings, 19 (December 2001): 35-47; "Das schreckliche Elend vor Moskau," Die Mennonitische Rundschau (hereafter MR), Winnipeg, MB, 18 December 1929, 1, 11; "Wanderungen," MR, 4 December 1929, 6; "Aus der alten Heimat," DB, 29 January 1930, 4; "Die Epidemie im Hammersteiner Flüchtlingslager," $M R$, 29 January 1930, 7; “Aus der alten Heimat,” DB, 12 February 1930, 4; Colin P. Neufeldt, "Separating the Sheep from the Goats: The Role of Mennonites and Non-Mennonites in the Dekulakization of Khortitsa, Ukraine (19281930)," Mennonite Quarterly Review 83, no. 2 (April 2009): 256-8, 287-8; Colin Neufeldt, "Reforging Mennonite Spetspereselentsy: The Experience of Mennonite Exiles at Siberian Special Settlements in the Omsk, Tomsk, Novosibirsk and Narym Regions (1930-33)," Journal of Mennonite Studies 30 (2012): 269-314. 
24. DaZo: R-235/4/212; R-235/3/28; R-235/3/47; R-235/5/79; PR-226/1/29.

25. R.W. Davies, The Socialist Offensive, 1929-1930 (Cambridge: Harvard University Press, 1980), 6, 166; Danilov, et al., Tragediia sovetskou derevni, tom 1:740, 746; 2:61, 85; Lynne Viola, The Best Sons of the Fatherland (Oxford: Oxford University Press, 1987), 43; DaZo: R-286/1/228.

26. Danilov, et al., Tragediia sovetskoi derevni, tom 2:11; R.W. Davies and Stephen Wheatcroft, The Years of Hunger: Soviet Agriculture, 1931-1933 (New York: Palgrave Macmillan, 2004), 4; Viola, The War Against the Peasantry, 216; Davies, The Soviet Collective Farm, 46.

27. Danilov, et al., Tragediia sovetskoŭ derevni, tom 2:85; DaZo: R-235/4/208; Davies, The Soviet Collective Farm, 5, 57, 68.

28. Stalin, Sochineniia, tom 12:191.

29. Danilov, et al., Tragediia sovetskor derevni,tom 2:364; Valeriĩ Vasyl'ev, and Lynne Viola, eds., Kollektivizatsiia i krest'ianskoe soprotivlenie na Ukraine: noiabr' 1929-mart 1930 g.g. (Vinnytsia: Lohos, 1997), 152, 204. In Ukraine the percentage of collectivized households dropped to 41.3 percent by 1 May 1930 . I. Kh. Hanzha, L.V. Huseva, and I.L. Sherman, eds., Istoriia kolektyvizatsii sil's 'koho hospodarstva Ukraïns' 'koï RSR, 1917-1937 rr.; zbirnyk dokumentiv $i$ materialiv. 3 vols. (Kyïv: Vyd-vo Akademiï nauk Ukr. RSR, 1962), tom 2:449.

30. Danilov, et al., Tragediia sovetskoù derevni, tom 2:598, 613, 725, 786; tom 3:95, 130; Davies, The Soviet Collective Farm, ix; Davies et al, The Years of Hunger, $1,18$.

31. DaZo: R-235/4/36; R-235/4/53; R235/4/56; R-235/4/62; R-235/1/815;

R-235/1/781; R-235/1/823; R-235/2/138; R-235/1/811; R-235/1/730;

R-3452/1/21; R-286/1/108; R-3452/1/21; R-286/1/115.

32. DaZo: R-862/1/35; R-235/2/133; R-286/1/398; R-286/1/108-09;

R-286/1/123; R-286/1/111; R-286/1/115-16; R-286/1/406. 
33. Heinrich G. Rempel served as Khortytsia REC chairman in 1928-29 and Johann P. Quiring during the first half of 1930. Penner served as Molochansk REC chairman in 1932. For other Mennonites who served in the Khortytsia and Molochansk REC and RPC, see DaZo: R-235/1/811; R-286/1/394; R-235/2/138; R-235/1/813; R-235/1/757; R-235/1/808; PR-7/1/132; R-286/1/254; R-286/1/22729; R-286/1/120; R-286/1/397; R-286/1/170; R-286/1/190; R-286/1/107; R-286/1/114-16; R-286/1/192; R-286/1/216; R-286/1/406; R-286/1/207; OZoKPU: 1/1179/49.

34. DaZo: R-286/1/400; R-286/1/271.

35. DaZo: R-286/1/114; R-286/1/232; R-286/1/406; R-235/4/211; R-235/2/61.

36. DaZo: R-235/1/766; "Wie sich unsere Lage allmählich verschlechtert," $D B$, 20 May 1931, 5; DaZo: R-235/4/129; R-3452/1/7; R-235/2/95; R-235/2/67; “Aus der Ukraine," DB, 14 May 1930, 4; "Ein Brief aus Russland," Zionsbote (hereafter ZB), Hillsboro KS, 9 April 1930, 12.

37. DaZo: R-235/1/731; R-235/1/814; R-235/2/58; R-235/1/825.

38. DaZo: R-235/4/61; R-235/4/367; R-235/4/21; R-235/4/75; R-235/4/79; R-235/4/208; R-235/4/187; R-235/4/62; R-235/1/813; R-235/1/809; Julius Loewen, Jasykowo: Ein mennonitisches Siedlungsschicksal am Dnjepr. Gründung Blüte-Untergang (Winnipeg, MB: n.p., 1967), 56.

39. DaZo: R-235/1/823; R-235/2/144; R-235/4/79; R-235/4/190; R-235/1/730; R-235/4/21.

40. DaZo: R-3452/1/3.

41. DaZo: R-286/1/109; R-286/1/120; R-286/1/389; R-286/1/103; Hanzha, et al., Istoriia kolektyvizatsii, tom 2:336.

42. DaZo: R-286/1/120; R-286/1/170-71; R-286/1/115; R-286/1/147;

R-286/1/214; R-286/1/166; R-235/4/305.

43. DaZo: R-235/4/123. 
44. Ibid.

45. Ibid.

46. DaZo: R-235/4/123; R-239/4/212; R-235/4/212.

47. DaZo: R-235/4/110; R-1429/1/12; R-2953/1/4; R-235/4/21; R-235/1/814.

48. DaZo: R-235/4/123; R-286/1/170; R-286/1/397.

49. DaZo: R-286/1/20; R-235/1/814. For anyone interested in the names of Mennonites who served as kolkhoz chairmen in Khortytsia or Molochansk, contact the author or see DaZo: R-235/4/110; R-235/4/79; R-862/1/35;

R-235/2/133; R-235/1/814; R-235/4/123; R-235/5/72; R-235/4/127; R-235/1/757;

R-235/1/816; R-235/2/165; R-3452/1/28; R-3452/1/7; R-3452/1/10; R-3452/1/6;

R-1429/1/12; R-3452/1/18; R-3452/1/24; R-3452/1/9; R-286/1/399; R-286/1/103;

R-286/1/108; R-286/1/115-19; R-3452/1/20-21; R-3452/1/24; R-286/1/416;

R-286/1/406; R-286/1/120; R-286/1/133; R-286/1/251; R-286/1/397;

R-286/1/166; R-286/1/192; R-286/1/146; R-286/1/194; R-3452/1/9; R-226/1/29;

R-286/1/192; R-1429/1/54; OZoKPU: 286/73/251; Staschkewitsch, "Nicht naktes Administrieren, sondern konkrete Leitung," ST, 4 October 1934, 2; Redekop, "Wir erklären uns als Stürmer," ST, 2 April 1934, 2; "Ehrentafel," ST, 28 March 1934, 1; Oese, "Der Kampf gegen den grünen Feind - schwach," ST, 28 May 1934, 2; Tschuchrei, "Mehr Arbeitsdisziplin!" ST, 4 July 1934, 1; Heinrich, "Den Plan der Silosierung überboten," ST, 15 August 1934, 2.

50. DaZo: R-3452/1/25; R-286/1/397; R-226/1/29; R-286/1/399; R-286/1/416; R-286/1/406; R-3452/1/9; R-3452/1/10; OZoKPU: 286/73/251.

51. Danilov, et al., Tragediia sovetskou derevni, tom 2:130; Philip Walters, “A Survey of Soviet Religious Policy" in Religious Policy in the Soviet Union, ed. Sabrina Petra Ramet (Cambridge: Cambridge University Press, 1993), 14.

52. DaZo: R-235/1/742; R-3452/1/21; "Friedensruhe, Molotschna, “ $D B, 23$ December 1931, 3.

53. DaZo: R-3452/1/20. 
54. DaZo: R-235/4/123.

55. DaZo: R-3452/1/24.

56. DaZo: R-235/1/823; R-3452/1/21; R-235/1/825; R-3452/110; "Wir haben unsere Kollektive durch die Entkulakisierung gewonnen,” $D B, 30$ April 1930, 4; B.H. Unruh, "Bericht XXX," 3 July 1931, Centre for Mennonite Brethren Studies, Winnipeg, MB.

57. “Ausländische,” $M R, 10$ February 1932, 6; DaZo: R-3452/1/24; R-1429/1/12; Jacob Rempel, Liebenau (Winnipeg, MB: n.p., 1977), 139; “Ausländische,” $M R$, 4 June 1930, 8; Jacob A. Neufeld, Tiefenwege (Virgil, ON: Niagara Press, 1954), 27.

58. DaZo: R-235/1/825.

59. DaZo: R-235/1/825; R-235/8/814.

60. DaZo: R-3452/1/12; R-3452/1/14.

61. Danilov, et al., Tragediia sovetskou derevni, tom 3: 90, 96; Davies et al., The Years of Hunger, 37.

62. DaZo: R-286/1/192; R-3452/1/7; R-235/1/816.

63. DaZo: R-3452/1/20; R-286/1/147; R-286/1/232; R-3452/1/7.

64. DaZo: R-286/1/251; R-3452/1/10.

65. DaZo: R-286/1/109.

66. DaZo: R-3452/1/20.

67. DaZo: R-235/4/126; R-235/1/816; R-235/4/126; R-235/4/283; R-286/1/108; R-235/1/731.

68. DaZo: R-3452/1/21; R-3452/1/10. 
69. DaZo: R-235/1/825; R-235/1/742; R-286/1/109.

70. DaZo: R-3452/1/7; R-235/2/56; “Trauriger Brief aus Russland," $M R, 8$ April 1931, 7; J. Niebur, "Im Kampfe für die vorfristige Ablieferung des Getreides," ST, 4 July 1934, 2; DaZo: R-3452/1/16.

71. DaZo: R-286/1/109.

72. Ibid.; DaZo: R-286/1/120; R-286/1/109.

73. DaZo: R-3452/1/21; R-235/1/825; "Ehrentafel," ST, 28 March 1934, 1; Peter, "Mehr politische Bildung," ST, 2 April 1934, 2.

74. DaZo: R-235/1/731a; R-3452/1/20; R-3452/1/21.

75. DaZo: R-286/1/406; “Ehrentafel,” ST, 28 March 1934, 1.

76. DaZo: R-3452/1/17.

77. DaZo: R-3452/1/7; R-3452/1/10; R-235/1/731.

78. Davies, The Soviet Economy in Turmoil, 84, 252; Hiroaki Kuromiya, Stalin's Industrial Revolution: Politics and Workers, 1928-1932 (Cambridge: Cambridge University Press, 1988), 238.

79. Davies et al., The Years of Hunger, 349; DaZo: R-3452/1/17; R-3452/1/6; R-3452/1/18; R-3952/1/20, R-1429/1/35; Unruh, “Bericht XXIV,” March 1931; "Im Kollektiv 'Triumph' macht man sichs bequem," ST, 2 April 1934, 2; "Ueber die Lohnsätze der Traktoristen," ST, 25 March 1934, 1; “Ausländische,” MR, 25 February 1931, 6.

80. DaZo: R-3452/1/17; R-235/1/825; R-3452/1/10; R-3452/1/16; R-3452/1/18.

81. DaZo: R-286/1/142.

82. DaZo: R-3452/1/24; R-235/4/290; R-235/4/303. 
83. DaZo: R-3452/1/10; R-3452/1/6; R-2953/1/4; R-1429/1/27; R-3452/1/25; R-235/4/123; R-3452/1/7.

84. DaZo: R-235/4/21.

85. DaZo: R-235/4/21; R-235/1/731a.

86. DaZo: R-3452/1/20; R-3452/1/10; R-3452/1/17; R-235/1/731; R-235/4/21; R-3452/1/24; R-235/1/825.

87. DaZo: R-235/1/766; R-235/4/110; R-235/4/2; R-235/1/815; R-3452/1/24;

R-235/4/21; R-3452/1/15.

88. “Den Kampf gegen den Getreidekâfer verstärken,” ST, 22 June 1934, 1; "Kollektive folgt dem Beispiel der Kollektive 'Litwinow,' 'Dimitrow,' und 'Ernst Thâlmann,' ST, 22 June 1934, 1; “Für bolschewistische Tempos!,” ST, 4 July 1934, 2; DaZo: R-3452/1/9.

89. “Ehrentaftel,” ST, 28 March 1934, 1.

90. Sapiets, "Anti-religious Propaganda and Education," 95; Rothenberg, "The Legal Status of Religion in the Soviet Union," 72-74; Walters, "A Survey of Soviet Religious Policy,” 13.

91. DaZo: R-235/3/45; R-3452/1/21.

92. DaZo: R-3452/1/11; R-235/1/771; R-235/1/814; R-3452/1/10.

93. Dück, "Hier mit einer Gottlosenzelle!," ST, 24 April 1934, 2; "Die Kindererziehung auf den ersten Platz!," ST, 28 March 1934, 2; "Wir haben mit der ewig verdummenden Kirche gebrochen," ST, 18 April 1934, 2.

94. DaZo: R-3452/1/251; R-3452/1/24; R-3452/1/21; R-235/1/823; R-286/1/227; R-3452/1/10; R-286/1/232; R-3452/1/9; "Wir haben uns der Stalin-Estafette angeschlossen," ST, 22 June 1934, 1. 
95. Buchmann, “Im Kollektiv 'Chelborob' wird der sagenhafte Christus nicht auferstehen,” ST, 14 April 1934, 2.

96. Keil, "Still und Ruhig ...” ST, 22 August 1934, 2.

97. The 1929 chistka of the party focused on those party members and candidates who had defects in their personal characters, were considered to be alien elements, were passive, were involved in criminal activity, or had violated party discipline. By 1930 approximately 11 percent of all party members in the Soviet Union had been expelled. The 1929 chistka was carried out in party organizations in Khortytsia and Molochansk, and it also inspired local officials to initiate their own chistki in non-party organizations in Molochansk (August-October, 1929 ) and Khortytsia (December 1929-January 1930). In the Molochansk raĭon, more than 25 percent of those Mennonites who were examined by non-party chistki commissions (which often included Mennonites) were expelled from their positions in the raǐon soviet, village soviets, local factories, kolkhozy, agricultural associations, Lesenhallen, Bauernheime, and medical facilities. The most common reasons cited for their expulsion included the following: participating in active resistance against the Soviet state; having a connection to a former landowner, kulak, or ekspertnik; being a member of an alien element; having a counter-revolutionary family member; performing unacceptable public work; owning too much land; or being an "unknowledgeable" worker. Some Mennonites who were not expelled from their positions were nonetheless reprimanded for their un-Soviet activities. Local officials also considered "emigration fever" as a serious problem in the Mennonite communities, and used the chistki as a means to punish them for the attempts of some of their members to leave the country. Emel'ian Iaroslavski1̌, Chistka partii: doklad na sobranii aktiva Moskovskoŭ organizatsii VKP(b) 29 marta 1929 g.: tezisy doklada na ob"edinennom plenume TSK i TSKK VKP(b) (Moskva: Gos. izd-vo, 1929); J. Arch Getty, Origins of the Great Purges: The Soviet Communist Party Reconsidered, 1933-1938 (Cambridge: Cambridge University Press, 1985),4348; DaZo: R-1415/3/1; R-235/1/766; R-235/1/814; R-235/1/815; PR/7/1/135; PR/7/1/136a; R-235/3/40; Neufeldt, "Separating the Sheep from the Goats," 25962.

98. DaZo: R-235/1/766; R-235/4/110; R-235/4/2; R-235/1/815; R-3452/1/24; R-235/4/21. 
99. “Pferdeschinder," ST, 12 July 1934, 1; “Treibt die Freundschaft auseinander!," ST, 12 July 1934, 2; DaZo: R-3452/1/15.

100. DaZo: R-286/1/107; R-286/1/111.

101. DaZo: R-286/1/171/1.

102. "Wie wird die untere Dorf-Parteiorganisation aufgebaut," ST, 28 March 1934, 1; DaZo: R-1429/1/12; R-3452/1/7; R-286/1/251; OZoKPU: 286/73/251; “Anstatt zum Korrespondententreffen —zur Hochzeit," ST, 16 September 1934, 2; "Protektionswirtschaft in Kollektiv 'Rote Fahne," ST, 10 July 1934, 1; "Wir würden, aber es geht nicht...” ST, 22 July 1934, 1.

103. DaZo: R-2861/109; R-286/1/166; R-286/1/130; R-286/1/115-16.

104. "Aus der Ukraine," $D B, 14$ May 1930, 4; "Aus der alt. Heimat," DB, 17 February 1932, 5; DaZo: R-1429/1/20; "Arbeitstage, die nie verdient wurden," ST, 16 September 1934, 2; "Die einen essen—die andern sollen zahlen," ST, 16 September 1934, 2.

105. DaZo: R-286/1/251.

106. "Nicht naktes Administieren, sondern konkrete Leitung," ST, 4 October $1934,2$.

107. DaZo: R-286/1/166; R-235/2/56; “Alles nur keine Qualitätsarbeit,” ST, 12 July 1934, 1; "Der Wirtschaftsleiter für die eigene Wirtschaft," ST, 12 July 1934, 2; “Ausländisches," MR, 8 April 1931, 7; Rempel, Liebenau, 146; Weiss, “Trinkwasser aus dem Viehtrog und noch mehr," ST, 10 July 1934, 2. For a discussion of the public's use of letters to denounce Soviet officials in the 1930s, see Sheila Fitzpatrick, "Signals from Below: Soviet Letters of Denunciation of the 1930s," The Journal of Modern History, 68.4 (1996), 831.

108. "Ehrentafel," ST, 28 March 1934, 1; "Wir erklären uns als Stürmer," ST, 2 April 1934, 2; Wiebe, "Und was macht die Verwaltung," ST, 22 July 1934, 2. 
109. "Kulakenagenten an der Spitze," ST, 23 July 1934, 2; “Treibt die Freundschaft auseinander!," ST, 15 July 1934, 2; Giesbrecht, "Die Aussaat hinausgezogen," ST, 6 September 1934, 1; "Verlauf der Herbstaussaat in den Kollektiven unserer EMTS,” ST, 3 September 1934, 2.

110. “Der Vorsitzende des Kollektivs 'Dmitrow' erzählt,” ST, 24 August 1934, 1; “Unnùtze Überlastung der Pferde," ST, 24 August 1934, 1.

111. DaZo: R-286/1/146.

112. DaZo: R-235/1/731a.

113. DaZo: R-3452/1/21; R-286/1/192; R-3452/1/18; R-3452/1/20.

114. DaZo: R-235/4/21; R-235/1/816.

115. DaZo: R-235/1/731; R-235/4/110; R-235/1/816.

116. DaZo: R-235/1/731; R-235/3/47; R-235/3/48; R-235/1/808; Colin P. Neufeldt, "The Zborni of Khortytsia, Ukraine: The Last Stop for Some Kulaks Enroute to Stalin's Special Settlements," in Confronting the Past. Ukraine and its History, 882-2009. A Festschrift in Honour of John-Paul Himka on the Occasion of his 60th Birthday, eds. Andrew Gow, Roman Senkus, and Serhy Yekelchyk, Journal of Ukrainian Studies 35-36 (2010-11): 207-23.

117. Davies et al, The Years of Hunger, 406; Stanislav V. Kul'chyts'ky1̆, Holodomor 1932-1933 rr. iak henotsyd: trudnoshchi usvidomlennia (Kyïv: Nash chas, 2008); Hiroaki Kuromiya, "The Soviet Famine of 1932-33 Reconsidered," Europe-Asia Studies 60, no. 4 (2008): 663; David Marples, Heroes and Villains: Creating a National History in Ukraine (Budapest: Central European University Press, 2007), 13.

118. Danilov, et al., Tragediia sovetskou derevni, tom 3:372, 402, 516; Michael Ellman, "Stalin and the Soviet Famine of 1932-33 Revisited," Europe-Asia Studies 59, no. 4 (2007): 663; R. W. Davies and Stephen G. Wheatcroft, "Stalin 
and the Soviet Famine of 1932-33: A Reply to Ellman," Europe-Asia Studies 58, no. 4 (June 2006): 627; Davis et al, The Years of Hunger, 424, 440.

119. Danilov, et al., Tragediia sovetskŏ derevni, tom 3:218, 227; Yuri Shapoval ed., The Famine-Genocide of 1932-1933 (Kingston, ON: Kashton Press, 2005), 3, 103; David R. Marples, "Ethnic Issues in the Famine of 1932-33," Europe-Asia Studies 61, no. 3 (May 2009): 511.

120. Danilov, et al., Tragediia sovetskoŭ derevni, 3:438; Stanislav V. Kulchytsky, Holodomor in Ukraine 1932-33: Interpretation of Fact (Kyiv: National Academy of Sciences of Ukraine, 2008), 60.

121. DaZo: R-3452/1/20.

122. Ibid.; DaZo: R-286/1/115; R-286/1/166.

123. Danilov, et al., Tragediia sovetskou derevni, tom 3:453, 525; Harold Berman, Soviet Criminal Law and Procedure (Cambridge: Harvard University, 1972), 29; Davies, et al, The Years of Hunger, 165.

124. Kulchytsky, Holodomor in Ukraine 1932-33, 62; Danilov, et al., Tragediia sovetskoù derevni, tom 3:541.

125. Danilov, et al., Tragediia sovetskoŭ derevni, tom 3:575.

126. David Shearer, Policing Stalin's Socialism: Repression and Social Order in the Soviet Union, 1924-1953 (New Haven: Yale University Press, 2009), 193, 243, 278; Gijs Kessler, "The Passport System and State Control over Population Flows in the Soviet Union, 1932-1940," Cahiers du Monde russe 42, nos. 2-4 (Apr-Dec 2001): 477.

127. Shearer, Policing Stalin's Socialism, 278-84; Robert Beattie, “A Great Turn that Never Happened: A Reconsideration of the Soviet Decree of Labor Discipline of November 1932," Russian History 13, nos. 2-3 (Summer-Fall 1986), 254-5.

128. Danilov, et al., Tragediia sovetskǒ derevni, tom 3:541. 
129. DaZo: R-3452/1/20; R-3452/1/18; R-3452/1/24; R-3452/1/9.

130. Shapoval, The Famine-Genocide, 215; Danilov, et al., Tragediia sovetskor derevni, tom 3:562.

131. Danilov, et al., Tragediia sovetskou derevni, tom 3:516, 562; Shapoval, The Famine-Genocide, 8.

132. Danilov, et al., Tragediia sovetskoŭ derevni, tom 3:634.

133. DaZo: R-3452/1/20-21; R-286/1/237; R-286/1/229; R-286/1/216;

R-286/1/170; R-286/1/114-16; R-286/1/120.

134. DaZo: R-3452/1/20; R-3452/1/24; R-286/1/251; R-3452/1/21.

135. DaZo: R-3452/1/20; R-3452/1/24.

136. DaZo: R-3452/1/20; R-3452/1/21.

137. DaZo: R-3452/1/20; R-286/1/115; R-3452/1/21; R-3452/1/18; R-3452/1/24.

138. DaZo: R-3452/1/20; R-3452/1/18.

139. DaZo: R-3452/1/24; R-286/1/115; R-3452/1/20.

140. DaZo: R-286/1/166.

141. DaZo: R-3452/1/18; R-3452/1/24; R-286/1/251.

142. DaZo: R-286/1/141.

143. "Schöneberg, Chortitzer Wolost," DB, 22 February 1933, 5; "An alle meine Freunde und Bekannten in Amerika," MR, 28 February 1934, 6; "Aus dem Halbstädter Rayon," DB, 1 June 1932, 3.

144. "Wir haben uns der Stalin-Estafette angeschlossen," ST, 22 June 1934, 1. 
145. "Alle in den Kampf fuer die Entfaltung der Kulturmassenarbeit!," $S T, 18$ January 1934, 2; "Das Artel 'Chleborob' im Kampfe," ST, 25 March 1934, 2; Rempel, Liebenau, 142; "Wie wir kampfen,” ST, 5 April 1934, 2; J. Braun, "Ens stiehlt Sonnenblumen," ST, 16 September 1934, 1; "Schadlingsarbeit," ST, 23 July 1934, 1 .

146. DaZo: R-286/1/130.

147. DaZo: R-3452/1/9; R-3452/1/18; R-3482/1/13.

148. DaZo: R-3452/1/24.

149. DaZo: R-3452/1/9; R-3452/1/18; R-3452/1/24; R-286/1/118/13a; R-286/1/120.

150. DaZo: R-286/1/166; R-286/1/170.

151. DaZo: R-286/1/192; R-3452/1/9; R-1429/1/36; “Aufbau?” MR, 17 February 1932, 11; OZoKPU: 286/82/5.

152. DaZo: R-286/1/115.

153. DaZo: R-1429/1/12; R-3452/1/16.

154. DaZo: R-3452/1/20; R-1429/1/12; Staschkewitsch, "Nicht naktes Administrieren, sondern konkrete Leitung," ST, 4 October 1934, 2;

"Kulakenagenten an der Spitze," ST, 23 July 1934, 2; "Wer is Schellenberg?," ST, 21 May 1934, 2

155. DaZo: R-3452/1/9.

156. DaZo: R-286/1/251.

157. DaZo: R-235/2/97.

158. DaZo: R-3452/1/18; R-286/1/170; R-286/1/115. 
159. DaZo: R-286/1/120.

160. DaZo: R-3452/1/20; R-3452/20/54; R-3452/1/6; R-3452/1/7;

R-3452/1/9; R-3452/1/10; R-3452/1/18; R-3452/1/21; R-286/1/166;

R-286/1/216; R-286/1/399.

161. Ibid.

162. DaZo: R-286/1/166.

163. DaZo: R-286/1/169; R-286/1/192.

164. J. Arch Getty and Oleg V. Naumov, The Road to Terror: Stalin and the Self-destruction of the Bolsheviks, 1932-1939 (New Haven: Yale University Press, 1999), 74-6, 125-8; Getty, Origins of the Great Purges, 49-57; Lynne Viola, "The Second Coming: Class Enemies in the Soviet Countryside, 19271935," in Stalinist Terror: New Perspectives, eds. J. Arch Getty and Roberta T. Manning (Cambridge: Cambridge University Press, 1993), 74-7.

165. DaZo: R-286/1/192.

166. DaZo: R-286/1/406; R-286/1/216; R-286/1/170; R-286/1/216; R-286/1/207; R-286/1/191.

167. DaZo: R-286/1/166; Shearer, Policing Stalin’s Socialism, 215.

168. DaZo: R-286/1/170; R-286/1/146; R-286/1/192; R-286/1/182.

169. DaZo: R-286/1/393; R-286/1/192/8a; R-286/1/146; R-1429/1/54; R-286/1/192; OZoKPU: 286/2/5.

170. DaZo: R-286/1/216; PR-226/1/29; PR-226/1/29.

171. In late 1933, for example, the following non-Mennonite chairmen controlled kolkhozy largely populated by Mennonites: Shlezevsky at Molochansk; Doroshenko at Muntau; Zverev at Petershagen; Murmel at Tiegenhagen; Mepel at Fischau; Alin at Lindenau; Possen at Lichtenau; 
Possen at Blumstein; Komadei at Münsterburg; Poplavsky at Ohrloff; Eirich at Rosenort; Luchko at Blumenort; and Krupke at Tiege. A few Mennonitesincluding Suderman at Altonau, T. Fast at Schardau, Pankratz at Gnadental, and Derksen at Schonau-were still managing Molochansk kolkhozy in 1934, but many did not keep their positions for long. Suderman, for instance, was expelled from the party and the kolkhoz in mid 1935. In Khortytsia, some of the Mennonites still managing kolkhozy in 1934 included the following: Wiebe at Thälmann (Neuendorf); Rempel at Dniprstroľ (Einlage); Neufeld at Landmann (Neuendorf); Hamm at Kataevich (Khortytsia); Enns at Torgler (Khortytsia); Penner at Kolos (Kanzerovka); Unger at Faktor (Schöneberg); Pätkau at Rekord (Nieder Khortytsia/Blumengart); and Hamm at Hoffnung (Khronstal). By late 1934, some of the non-Mennonites who controlled important Mennonite kolkhozy in Khortytsia included the following: Paume at Khliborob (Neuenberg); Salmer at Triumph (Neu-Kronsweide); Engel at International (Nieder-Khortytsia); and Poukoyev at Schnitter (Burwalde). DaZo: R-286/1/134; R-286/1/393; R-286/1/270; R-286/1/194; R-286/1/280; R-286/1/281; R-286/1/133; R-286/1/306; R-286/1/389; R-286/1/392; R-286/1/415; R-286/1/406; "Ehrentafel,” ST, 28 March 1934, 1.

172. DaZo: R-286/1/419; R-286/1/136; R-286/1/352; R-286/1/353; R-286/1/371. Ilis et verum quas ad expla inveliquat experrum as molutate sit que samenti doleceperio beat.

Voluptius vendae nobissin repra quibus repellabo. Occab ipidem. Neque velitam, venihilit ut inctemo distis acepudae moloribus, quiae venda velibust, illa intemquam voluptate perisintem. Xerum simoluptas nestistrum eossi dolendam liquodicilit res estiat.

Itatent iur sim endenienis dolesti untur, sitis dolupta tectaep eriae. Bearumet quis et latemporae corum nullore pellacc aborro ent et lautam nobitat ibearis est ulparum hiliquiditis consecti idempos excesequi nonsent ea videne susti duntis maio. Gitat faceperum quodips andae. Volorion earupta sitio. Et liae lauditat dolorerovit iuscit renia apienem consere pratempore most et asimpos quam qui aliant rerferit et lantem hari bere dolupta nos simus, ipicia cupienit, consequam fuga. Unto doluptat volo odi volest ius imaximp orrovid quam andit od quo et aut fugitam, quis autatem olorest veles doloresti ium quunt harum exerum vel ius, qui consed quos sit, ut occaborerit et expellabo. Upta dolorei ctemqui berum laciminverum quam aliquamet esto enditem velectem voluptur? 